$$
\begin{gathered}
\text { UNIVERSIDADE DE BRASÍLIA } \\
\text { INSTITUTO DE CIÊNCIA POLÍTICA } \\
\text { PROGRAMA DE PÓS-GRADUAÇÃO EM CIÊNCIA POLÍTICA }
\end{gathered}
$$

LEANDRO ALVES CARNEIRO

IMPACTO DA GOVERNANÇA GLOBAL SOBRE A REGULAÇÃO BRASILEIRA: ESTUDO DO ARRANJO INSTITUCIONAL DA ÁREA DE RADIOCOMUNICAÇÕES 


\author{
UNIVERSIDADE DE BRASÍLIA \\ INSTITUTO DE CIÊNCIA POLÍTICA \\ PROGRAMA DE PÓS-GRADUAÇÃO EM CIÊNCIA POLÍTICA
}

IMPACTO DA GOVERNANÇA GLOBAL SOBRE A REGULAÇÃO

BRASILEIRA: ESTUDO DO ARRANJO INSTITUCIONAL DA ÁREA DE

RADIOCOMUNICAÇÕES

LEANDRO ALVES CARNEIRO

Dissertação apresentada ao Instituto de Ciência Política da Universidade de Brasília para obtenção do título de Mestre em Ciência Política.

Orientador: Prof. Dr. Denilson B. Coêlho

Brasília 


\author{
UNIVERSIDADE DE BRASÍLIA \\ INSTITUTO DE CIÊNCIA POLÍTICA \\ PROGRAMA DE PÓS-GRADUAÇÃO EM CIÊNCIA POLÍTICA
}

\title{
IMPACTO DA GOVERNANÇA GLOBAL SOBRE A REGULAÇÃO BRASILEIRA: ESTUDO DO ARRANJO INSTITUCIONAL DA ÁREA DE RADIOCOMUNICAÇÕES
}

LEANDRO ALVES CARNEIRO

Banca Examinadora:

Prof. Dr. Denilson Bandeira Coêlho - IPol/UnB

Prof. Dr. Paulo Carlos du Pin Calmon - IPol/UnB

Prof. Dr. Márcio Nunes lorio Aranha Oliveira - Direito/UnB

Prof. Dr. Mathieu Turgeon - IPoI/UnB (Suplente)

Brasília 
Ao meu amado filho Henrique, que, mesmo pequeno, tanto tem me ensinado. 


\section{Agradecimentos}

Agradeço, primeiramente, a Deus por ter me dado condições de chegar até aqui.

Agradeço aos membros da banca, especialmente ao meu orientador, Professor Denilson Bandeira Coêlho pelas recomendações que certamente tornaram este trabalho melhor. Agradeço também aos Professores Paulo Calmon e Pablo Holmes pelas discussões e pela indicação de bibliografia.

Agradeço aos meus pais e à minha irmã por estarem sempre ao meu lado, me incentivando e me apoiando em todos os momentos.

Por fim, agradeço especialmente à minha esposa Priscila, por compreender minhas ausências e pelo amor que me dá motivação de seguir em frente todos os dias. 


\section{Resumo}

As Agências Reguladoras são autarquias que sofrem influências de diversas naturezas, podendo levar à captura da entidade por algum agente. Neste trabalho, é estudada a possiblidade de captura da regulamentação de radiocomunicações, editada pela Anatel, por parte de agentes internacionais. Para isso, foram utilizadas teorias que remetem à governança global das agências, difusão de políticas públicas e orquestração. Este último, geralmente utilizado para estudar a governança em agências internacionais, foi combinado com teorias de difusão para compreensão da governança na Anatel. Como fonte de evidências empíricas, foram utilizadas as respostas da Anatel às contribuições recebidas em consultas públicas sobre o objeto de estudo. Com isso, foi possível verificar os principais impactos de questões internacionais na regulamentação nacional de radiocomunicações, bem como a importância do desenvolvimento tecnológico para a independência de Agências Reguladoras.

Palavras-chave: Agências Reguladoras

Anatel

Governança

Regulatória Espectro de radiofrequências Radiocomunicações

Telecomunicações Difusão de políticas públicas Orquestração

Desenvolvimento tecnológico 


\section{Abstract}

Regulatory Agencies are submitted to various influences, which may lead to capture by some agent. In this work, we studied the capture possibility, by international agents, of the radiocommunications regulation, issued by Anatel. Thus, theories of global governance, policy diffusion and orchestration are used. The orchestration model, often used to study the governance of international agencies, is combined with diffusion theories for the comprehension of Anatel's governance. As a source of empirical evidence, we used Anatel's responses to contributions received in public consultations about the topic studied. Therefore, it was possible to verify the major impacts of international issues on national radiocommunications regulation, as well as the importance of technological development for the independence of regulatory agencies.

Keywords: Regulatory Agencies Anatel Regulatory Governance Spectrum Radiocommunications Telecommunications Policy Diffusion Orchestration Technological development 


\section{Lista de Figuras:}

Figura 1 - Difusão das reformas regulatórias: top-down, bottom-up, ou

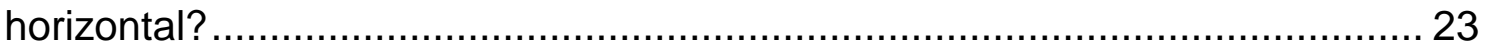

Figura 2 - Modelo principal-agente e Modelo de orquestração ....................... 30

Figura 3 - Quatro modos de governança.................................................. 30

Figura 4 - Comparação de crescimento entre serviços de informação e PIB no

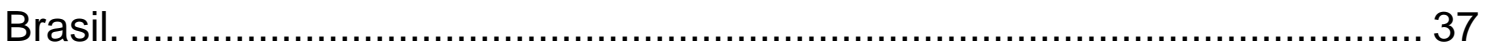

Figura 5 - Balança comercial de equipamentos de telecomunicações no Brasil

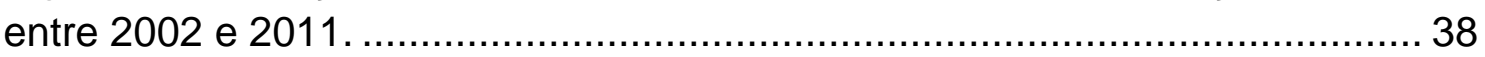

Figura 6 - Sistema Setorial de inovação em telecomunicações. ..................... 45

Figura 7 - Estrutura da UIT-R. ........................................................ 49

Figura 8 - Divisão em regiões adotada pela UIT. .................................. 53

Figura 12: Estrutura da Anatel.......................................................... 59

Figura 13 - Estrutura das CBCs....................................................... 61

Figura 14: Número de resoluções aprovadas pela Anatel relativas a radiofrequência............................................................................... 86

Figura 15 - Abertura de processos de regulamentação pela Anatel e realização

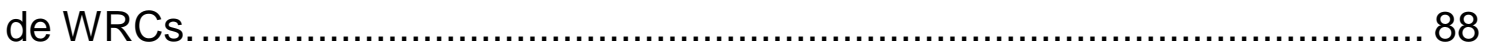

Figura 16 - Número de consultas públicas sobre radiocomunicações por ano.

Figura 17 - Distribuição da duração (em dias) das consultas públicas sobre radiofrequência........................................................................... 90

Figura 18 - Número de contribuições por consulta pública........................... 90

Figura 19 - Distribuição temporal da existência de resposta às contribuições. 91

Figura 20 - Número de contribuições com comentários por consulta pública. 92

Figura 21 - Distribuição das contribuições segundo contribuidor. .................. 95

Figura 22 - Distribuição das contribuições segundo contribuidor (detalhe).... 95

Figura 23 - Posição da Anatel sobre as contribuições recebidas. ...................96 96

Figura 24 - Posição da Anatel sobre as contribuições recebidas (detalhe).... 96

Figura 25 - Contribuições ou comentários da Anatel que mencionam a UIT... 97

Figura 26 - Contribuições ou comentários da Anatel que mencionam a UIT

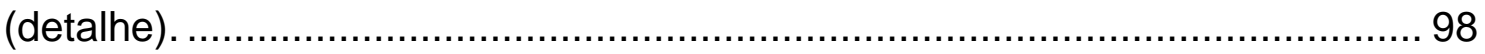

Figura 27 - Percentual de contribuições de acordo com o contribuidor......... 100

Figura 28 - Percentual de comentários positivos da Anatel de acordo com 0

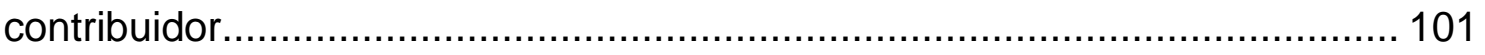

Figura 29 - Percentual de comentários negativos da Anatel de acordo com o

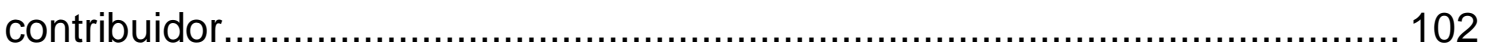

Figura 30 - Modelo de orquestração................................................. 103

Figura 31 - Inserção de mais um agente na cadeia de governança global, o intermediário............................................................................... 103

Figura 32 - Modelo de orquestração para o caso concreto estudado............ 105 
Figura 33 - Comparação entre o número de chairmen da UIT-R e a posição no ranking de patentes de telecomunicações.

108

Figura 34 - Modelo de orquestração aplicado para difusão de políticas públicas (transferência orquestrada de política pública)............................................. 119

Figura 35 - Modelo do Triângulo de Sábato. …………............................. 120 


\section{Lista de Tabelas:}

Tabela 1 - Características desejadas para autonomia de Agências Reguladoras.................................................................................... 25

Tabela 2 - Hipóteses para orquestração. .................................................. 32

Tabela 3 - Arrecadação e realização dos recursos do Funttel. ........................ 43

Tabela 4 - Séries de Recomendações da UIT-R........................................ 52

Tabela 5 - Trecho exemplificativo da tabela de alocações do RR................. 54

Tabela 6 - Funcionários em categorias superiores da UIT de acordo com sua

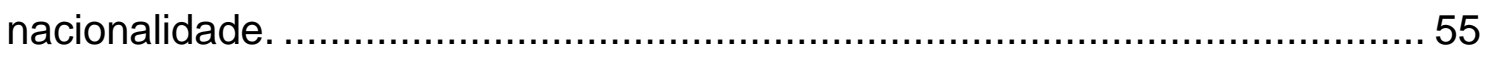

Tabela 7 - Membros setoriais brasileiros na UIT. ..................................... 56

Tabela 8 - Associados brasileiros na UIT........................................... 57

Tabela 9 - Membros brasileiros da academia na UIT............................... 57

Tabela 10 - Planejamento financeiro da UIT para 2016-2019...................... 58

Tabela 11 - Paralelo entre os temas tratados pela UIT, a estrutura das CBCs e a estrutura da Anatel. ........................................................................... 61

Tabela 12 - Situações para cada tipo de método de pesquisa....................... 75

Tabela 13 - Correspondência entre as agências reguladoras brasileiras e as agências especializadas da ONU...................................................... 77

Tabela 14 - Comparação entre as consultas públicas com e sem resposta.... 92

Tabela 15 - Aceitação das contribuições quando elas mencionam ou não a UIT. 98

Tabela 16 - Comparação entre as hipóteses para orquestração quando entendida como governança e como difusão.......................................... 116

Tabela 17 - Eventos da política de espectro em alguns países.................... 123

Tabela 18 - Distância temporal entre o Brasil e os países líderes na política de radiocomunicações. 


\section{Lista de Abreviaturas e Siglas:}

3GPP - 3rd Generation Partnership Project

ABINEE - Associação Brasileira da Indústria Elétrica e Eletrônica

APT - Asia-Pacific Telecommunity

ASMG - Arab Spectrum Management Group

ATU - African Telecommunications Union

BNDES - Banco Nacional do Desenvolvimento

CCV - Coordination Committee for Vocabulary

Citel - Comissão Interamericana de Telecomunicações

CPM - Conference Preparatory Meeting

$\mathrm{CPqD}$ - Centro de Pesquisa e Desenvolvimento

ERA - European Regulatory Agencies

ERN - European Regulatory Networks

FCC - Federal Communications Commission

FDTT - Fundo para o Desenvolvimento Tecnológico das Telecomunicações

Finep - Financiadora de Estudos e Projetos

Fistel - Fundo de Fiscalização das Telecomunicações

Funttel - Fundo para o Desenvolvimento Tecnológico das Telecomunicações

FUST - Fundo de Universalização dos Serviços de Telecomunicações

GSMA - Global System for Mobile Communications Association

IAP - Informatics, Administration and Publications Department

ICC - Interstate Commerce Commission

ICANN - The Internet Corporation for Assigned Names and Numbers

IEEE - Institute of Electrical and Electronics Engineers

IGO - International intergovernamental organizations

IMT - International Mobile Telecommnunications

IP - Internet Protocol

IRN - Independent Regulatory Networks

ISO - International Organization for Standardization

ITU - International Telecommunications Union

JTG - Joint Task Group

LGT - Lei Geral de Telecomunicações

LTE - Long Term Evolution 
MIFR - Master International Frequency Register

OEA - Organização dos Estados Americanos

ONU - Organização das Nações Unidas

RCC - Regional Commonwealth in the Field of Communications

Regulatel - Foro Latinoamericano de Entes Reguladores de

Telecomunicaciones

RRB - Radio Regulations Board

SC - Special Committee on Regulatory/Procedural Matters

SGD - Study Group Department

Serviço Móvel Celular e Pessoal

SMP - Serviço Móvel Pessoal

SSD - Space Services Department

SSI - Sistema Setorial de Inovação

Telebrasil - Associação Brasileira de Telecomunicações

TIC - Tecnologias da Informação e Comunicação

TSD - Terrestrial Services Department

UIT - União Internacional de Telecomunicações

UIT-D - Setor de Desenvolvimento da UIT

UIT-R - Setor de Radiocomunicações da UIT

UIT-T - Setor de Padronização da UIT

WIPO - World Intellectual Property Organization

WRC - World Radiocommunications Conference 


\section{IMPACTO DA GOVERNANÇA GLOBAL SOBRE A REGULAÇÃO BRASILEIRA: ESTUDO DO ARRANJO INSTITUCIONAL DA ÁREA DE RADIOCOMUNICAÇÕES}

\section{Sumário}

INTRODUÇÃO . 14

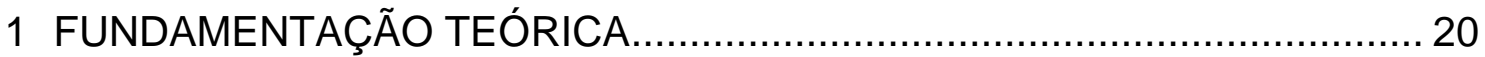

1.1 AGÊNCIAS REGULADORAS E GOVERNANÇA REGULATÓRIA.............20

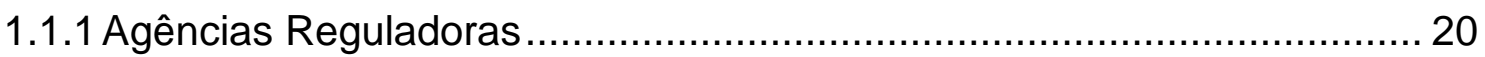

1.1.2 Governança Regulatória e Capitalismo Regulatório ............................... 23

1.2 TEORIA DE DIFUSÃO DE POLÍTICAS PÚBLICAS .................................. 26

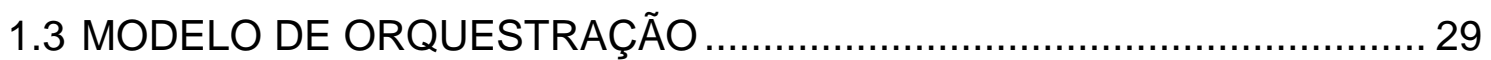

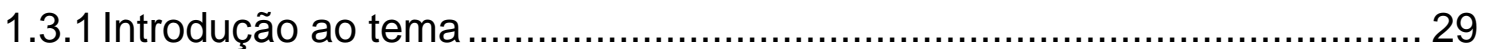

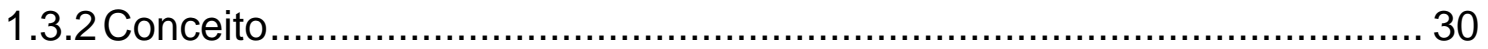

1.3.3 Premissas do modelo de orquestração................................................ 31

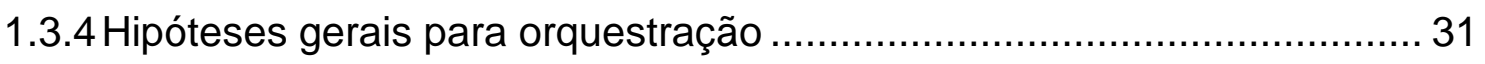

1.3.5 Adaptações necessárias para aplicação no caso concreto ..................... 33

2 DESCRIÇÃO DO ARRANJO INSTITUCIONAL DA ÁREA DE

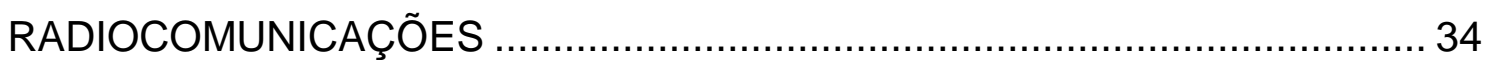

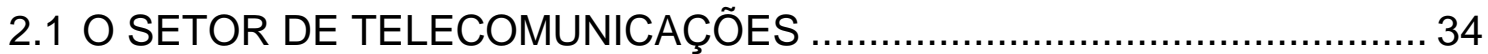

2.1.10 desenvolvimento tecnológico do setor de telecomunicações no Brasil 36

2.1.2O sistema setorial de inovação de telecomunicações brasileiro ............... 39

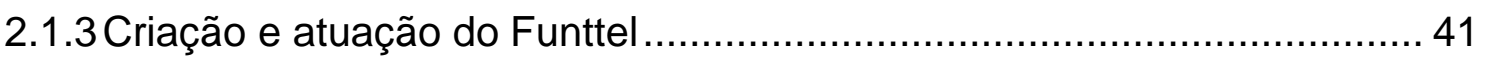

2.1.4 A criação de um Sistema Setorial de Inovação ..................................... 44

2.1.5 Descrição dos agentes, conforme a política vigente................................ 44

2.1.6 Algumas considerações iniciais sobre o modelo de SSI vigente ............. 46

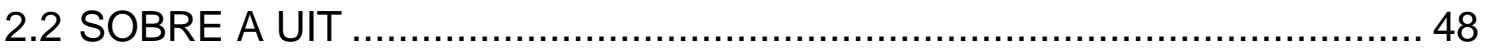

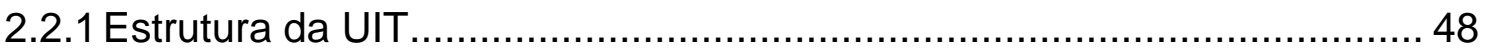

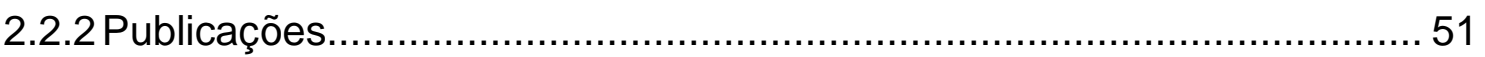

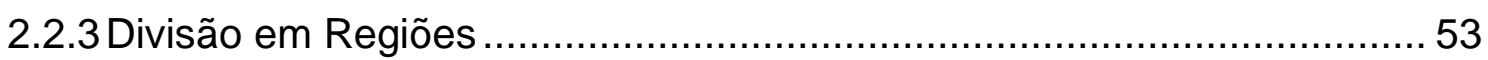

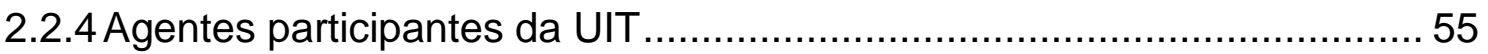

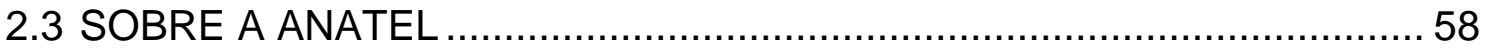

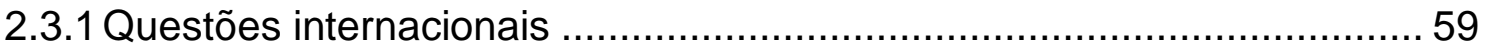


2.4 SOBRE RADIOCOMUNICAÇÕES E O ESPECTRO DE

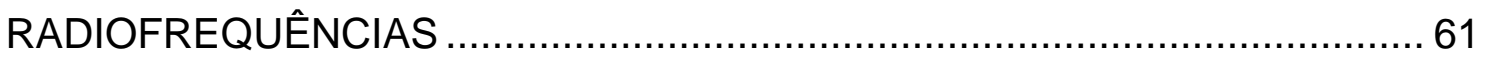

2.4.1 A Regulamentação de Espectro de Radiofrequências.......................... 65

2.4.2 Regulamentação de Espectro da Anatel...........................................6 67

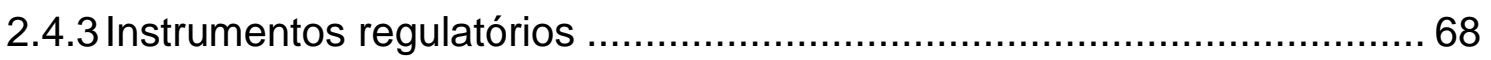

2.4.4 Princípio de neutralidade tecnológica na alocação de espectro .............. 69

2.4.5 $\mathrm{O}$ ecossistema de regulamentação relacionada a radiocomunicações ... 71

2.4.6 Agentes e seus interesses ........................................................... 72

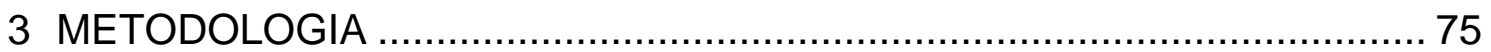

3.1 SOBRE O MÉTODO A SER UTILIZADO ........................................... 75

3.2 RECORTE DE PESQUISA ......................................................... 76

3.3 PERGUNTA DE PESQUISA E HIPÓTESES ..................................... 80

3.4 BASES DE DADOS: RESOLUÇÕES, CONSULTAS PÚBLICAS E

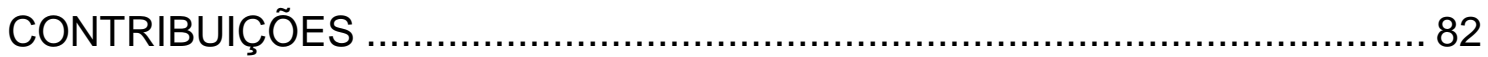

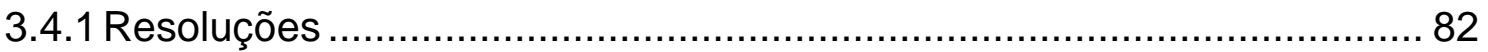

3.4.2 Consultas públicas ............................................................... 83

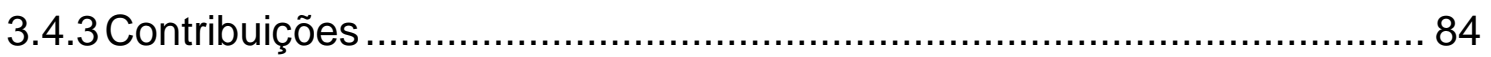

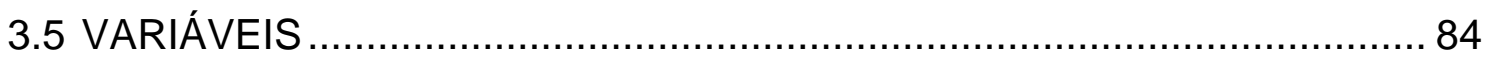

4 ANÁLISE DA INFLUÊNCIA INTERNACIONAL SOBRE A REGULAÇÃO DE

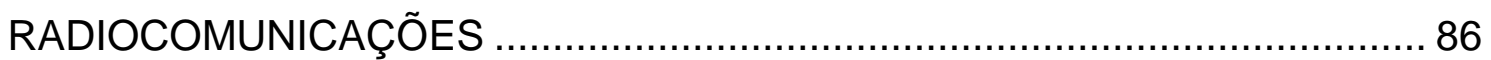

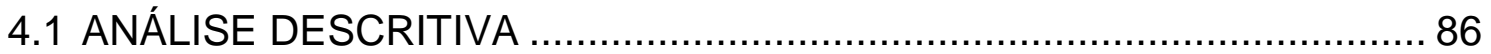

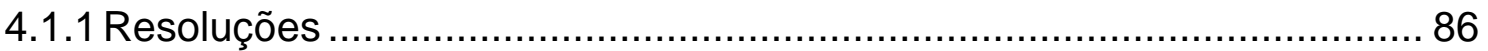

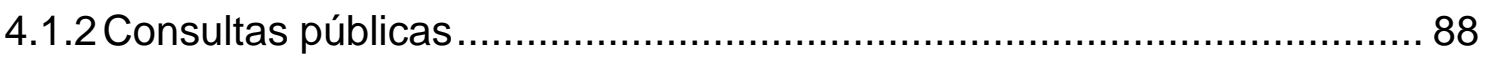

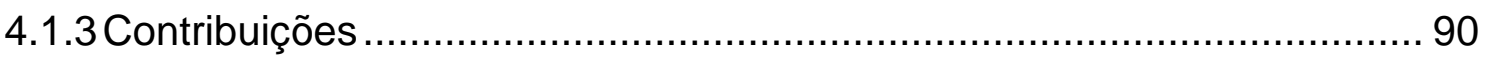

4.1.4 Contribuidores............................................................................ 93

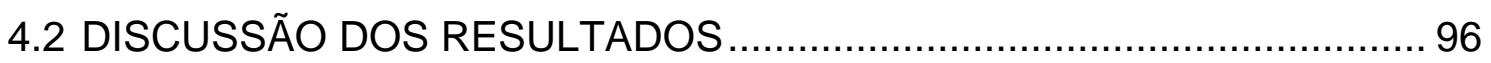

4.2.1 Desenvolvimento de um modelo de governança para o caso concreto. 103

4.2.2 Hipóteses teóricas para orquestração ................................................. 109

4.2.3 Desenvolvimento de um mecanismo de difusão para o caso concreto 114

4.2.4 Independência da Agência Reguladora e domínio tecnológico ............. 120

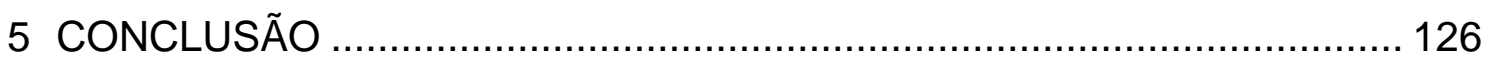

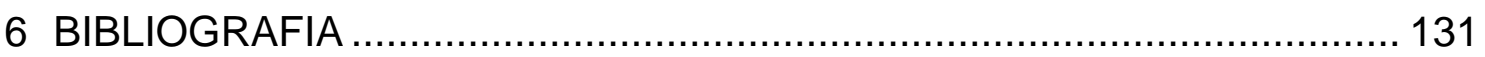




\section{INTRODUÇÃO}

O estudo de Agências Reguladoras Federais no Brasil se tornou um tema de grande interesse na Ciência Política brasileira nos primeiros anos do Século XXI. Por terem sido uma mudança institucional no cenário nacional, muitas respostas são buscadas, tais como: Quais fatores explicam o surgimento de cada uma das agências? Quais os mecanismos de prestação de contas e de controle sobre essas entidades? Há independência em suas decisões? Houve alguma mudança em seu funcionamento ao longo do tempo?

Um interesse especial surge em relação às agências devido à variedade de suas competências. Elas podem exercer funções geralmente associadas ao Poder Executivo, tais como a concessão e fiscalização de atividades; geralmente associadas ao Poder Legislativo, como edição de normas, regras e procedimentos; e funções geralmente associadas ao Poder Judiciário, ao julgar, impor penalidades, interpretar contratos e arbitrar conflitos entre os agentes regulados (NUNES, 2007). Todos esses poderes podem gerar externalidades positivas e negativas tanto aos agentes regulados, diretamente afetados, mas também ao próprio governo, uma vez que plataformas políticas podem ser construídas sobre a atuação dessas entidades.

Este ponto é bastante explorado por estudos sobre a governança dessas agências. A expansão do modelo de Agência Reguladora significa que mais aspectos da vida cotidiana serão decididos por instituições não eleitas ou que não estão sob o controle direto de políticos eleitos, com implicações diretas na formulação de políticas públicas (GILARDI e MAGGETTI, 2011). O caráter eminentemente técnico, utilizado para justificar a autonomia e a independência das agências, pode também ser uma fonte de problemas de governança, pois se assume que tais entidades serão tecnicamente capazes de superar problemas como a assimetria de informação, o risco moral (moral hazard), dentre outros.

A expansão desse tipo de desenho institucional está ligado à expansão de uma nova fase do capitalismo global, o capitalismo regulatório (LEVI-FAUR, 2005), o que gerou as chamadas "comunidades de políticas públicas" ou "redes de reguladores independentes". Estudos, especialmente na Europa, começaram a aprofundar sobre os métodos de atuação das "Redes 
Regulatórias Europeias" (European Regulatory Networks - ERN) e das agências reguladoras europeias para diversos setores (LEVI-FAUR-2011). Apesar de as agências nacionais europeias continuarem independentes e não haver qualquer relação de subordinação hierárquica, as redes e as agências supranacionais criaram uma série de mecanismos para constranger a adoção de padrões por parte das entidades nacionais (MAGGETTI, 2011).

Há que se observar que o objetivo geral dos organismos internacionais e dos "regimes internacionais" é buscar a harmonização, a convivência pacífica entre o que acontece em diversos países, reconhecendo a interdependência entre eles. Esse processo de harmonização também causa convergências, as quais são bastante estudadas em Relações Internacionais, mas pouco reconhecidas em estudos de políticas públicas domésticas (BENNETT, 1991), especialmente no Brasil.

A nova estrutura de governança (regulatory governance), com regras sobre transparências, prestação de contas (accountability), clareza, capacidade de tomada de decisões, dentre outras, são extremamente importantes para que as agências possam ser, de facto, independentes (regulatory independent agencies - RIA). Essa estrutura de governança é o que pode evitar captura, bem como dá estabilidade e previsibilidade sobre as ações desses agentes públicos. Essa previsibilidade possibilita investimentos mais seguros por parte de agentes nacionais e internacionais, já que as decisões devem ser imparciais em relação aos diferentes competidores daquele setor da economia. Por essas razões, uma série de estudos se dedicou a investigar a autonomia e a independência em relação ao Governo e ao mercado (CORREA, 2008; MONTOYA e TRILLAS, 2007; PÓ e ABRUCIO, 2006; MELO, 2004).

Questões de governança também são importantes no que se refere a Organismos Internacionais. Tomada de decisão, formação de agenda, prestação de contas, implementação de decisões são questões importantes para os Estados membros e outros agentes participantes ou impactados. Nesse contexto, surgiu o conceito de orquestração (ABBOTT, 2015), no qual esses Organismos Internacionais conseguem expandir sua atuação por meio de colaborações com entidades externas. Essas "parcerias" podem tanto 
facilitar a implementação de decisões tomadas, quanto podem contornar eventuais pontos de veto criados por algum Estado membro.

Esse mecanismo de governança é um importante conceito, pois insere um intermediário, no conhecido modelo Principal-Agente. Essa inovação conceitual propiciou uma explicação em que um agente, o orquestrador, pode fazer uso de intermediários para conseguir impactar em alvos específicos. Nessa situação, considera-se a orquestração um mecanismo indireto e soft. Indireto porque o orquestrador influencia o alvo tendo um intermediário que faz a atuação direta e soft porque a relação entre o orquestrador e o intermediário é de colaboração, ou seja, não mandatória.

O conceito de orquestração, apesar de ter sido criado para o contexto de governança em Organismos Internacionais, pode também ser aplicado às agências reguladoras. Essa aplicação expande as possibilidades geralmente estudadas de influência direta, viabilizando explicações de modos mais sofisticados de atuação. Essa possibilidade é especialmente interessante no Brasil, devido a algumas características que poderiam caracterizá-lo como alvo, por não ser um país tecnologicamente central na governança global, e já ter sofrido influências internacionais para implantação de Agências Reguladoras.

O surgimento das Agências Reguladoras no Brasil foi um fenômeno tardio em relação às economias capitalistas centrais. Um movimento iniciado especialmente pelas iniciativas de Margaret Thatcher no Reino Unido e Ronald Reagan nos EUA, com uma série de privatizações e reforço do papel regulador do Estado, em substituição ao papel de provedor de serviços. Entretanto, a experiência regulatória já existia de maneira consolidada nesses países, com instituições já bastante antigas, como o FCC (Federal Communications Commission), criado nos EUA em 1934.

No caso das agências brasileiras, uma vertente bastante presente na literatura nacional sobre o assunto é relativa ao surgimento dessas entidades. Essas pesquisas caracterizam muito bem como se deu o processo de criação dessas autarquias especiais, iniciando-se no primeiro governo $\mathrm{FHC} e$ estendendo-se até o governo Lula. Diversos são os modelos e teorias aplicáveis nesse caso para compreender o agendamento da política das privatizações, da desestatização e da descentralização, que tinham como 
operacionalização a criação das Agências Reguladoras (RAMALHO, 2009; NUNES, 2007; MELO, 2002; MOURA, 2014).

Desde então, já existiam estudos que vinculavam a criação das Agências Reguladoras brasileiras com experiências e influências advindas de fora do país (AMARAL, 2000; MELO, 2002). Esse fato sugere o mecanismo de difusão como um bom modelo para explicação do surgimento dessas agências, bem como coloca o Brasil da posição de influenciado e não de influenciador na escolha dos arranjos institucionais.

Apesar do grande interesse acadêmico relativo à gênese das agências, poucos ainda são os estudos relacionados à sua função na implementação de políticas públicas. A maioria dos estudos se dedica a compreender as políticas públicas de privatização e de criação dessas entidades, pavimentando o caminho para o campo de estudos relativo ao agendamento e à implementação das políticas (outputs) pelas Agências em seus mercados regulados. Este estudo pretende contribuir nessa vertente.

O que se deseja é problematizar a questão das influências, especialmente a internacional, como foi feito pelos estudos relativos à criação das Agências. Melo (2004), por exemplo, entende que a difusão internacional de um paradigma institucional se deu pela atuação de agências multilaterais, empresas de consultoria internacional, elites técnicas e outros agentes no plano doméstico. Esses agentes constituíram atores privilegiados de um processo complexo em que se conjugam mecanismos de aprendizagem social, formação de comunidades de políticas públicas, além de mecanismos reforçadores de certo isomorfismo organizacional (DIMAGGIO E POWELL, 1983). Tal processo pode ainda estar ocorrendo com as políticas públicas implementadas pelas Agências Reguladoras. Deseja-se, assim, verificar se as agências internacionais têm uma influência relevante na regulação setorial brasileira promovida por agências reguladoras.

No caso específico deste trabalho, pretende-se estudar, dentre as diversas capacidades das Agências Reguladoras, conforme descrito, a capacidade de edição de normas. De forma a conseguir evidência empírica mais robusta, houve a necessidade de se fazer um recorte temático temporal. Para isso, escolheu-se o setor de telecomunicações, setor que, desde 1997, 
com a publicação da LGT (Lei Geral de Telecomunicações), conta com uma Agência Reguladora, a Anatel. Além disso, o setor de telecomunicações apresenta uma agência especializada da ONU, a UIT (União Internacional de Telecomunicações). A existência de um fórum internacional indica a possibilidade de existência de um mecanismo facilitador na difusão de políticas públicas, bem como indica a possibilidade de existência de um mecanismo de governança global.

Entretanto, a regulamentação da Anatel e as publicações da UIT são bastante diversas. A regulamentação setorial trata, por exemplo, de direito do consumidor, aspectos técnicos para implementação de infraestrutura, ações voltadas ao estímulo da competição, dentre outras. As fontes de influências também podem variar muito de acordo com o tipo de regulamentação, já que diferentes grupos podem ser impactados de maneira distinta de acordo com o assunto tratado. Algumas questões podem envolver agentes internacionais, como políticas de competição, já que vários agentes são transnacionais e outras são bastante domésticas, como direito do consumidor. Assim, houve a necessidade de se fazer um recorte na regulamentação, buscando-se aspectos que podem ser influenciados por agentes internacionais, incluindo a UIT.

A regulamentação escolhida foi a de radiocomunicações, já que o tema envolve harmonização internacional. A harmonização internacional, neste caso, tem como objetivos evitar interferências em fronteiras ou em serviços globais, como comunicação via satélite, e possibilitar ganhos de escala, com equipamentos que sejam intercomunicáveis e que tenham menor custo de produção.

Para isso, o trabalho está dividido em 5 capítulos, além desta introdução. O capítulo 1 traz uma fundamentação teórica que embasa o restante do trabalho. Nesse capítulo é descrita a gênese das Agências Reguladoras e as principais características desse arranjo institucional. Há também uma descrição dos principais aspectos da governança regulatória e da expansão do Capitalismo Regulatório. Da mesma forma, é feita uma apresentação do modelo de orquestração, tratado por Abbott (2015) e das principais teorias de difusão de políticas públicas. 
O capítulo 2 apresenta uma caracterização e uma contextualização do objeto de estudo. São retratados aspectos do setor de telecomunicações, como a organização da Anatel e da UIT, bem como são detalhados aspectos específicos das radiocomunicações e do sistema setorial de inovação do setor de telecomunicações brasileiro. Essa contextualização é importante para que as peculiaridades do setor possam ser inseridas na aplicação de teorias mais gerais.

O capítulo 3 trata da metodologia utilizada. São explicados em maiores detalhes o recorte de pesquisa, a pergunta de pesquisa e as hipóteses a serem testadas, bem como a descrição das variáveis utilizadas.

A análise dos resultados empíricos e a aplicação dos conceitos apresentados no capítulo 2 é feita no capítulo 4. Primeiramente é feita uma análise descritiva dos resultados empíricos e posteriormente é desenvolvido um modelo de orquestração para o caso concreto. São também tecidas considerações sobre os resultados encontrados e uma ligação entre 0 desenvolvimento tecnológico do país no setor e a independência da agência reguladora setorial em relação a influências internacionais.

No capítulo 5 , é feita uma conclusão, na qual são apresentadas contribuições teóricas, bem como as contribuições sobre o funcionamento das Agências Reguladoras no Brasil.

Desta forma, pretende-se com o presente trabalho trazer à luz aspectos da governança das Agências Reguladoras, destacando, em especial, a importância do desenvolvimento tecnológico para a independência e autonomia na regulação. 


\section{FUNDAMENTAÇÃO TEÓRICA}

Neste capítulo, são apresentadas as principais teorias utilizadas neste estudo. Primeiramente, é apresentada a literatura que trata de Agências Reguladoras, com destaque para as teorias que subsidiaram a sua criação e que justificam a governança adotada nessas entidades governamentais. Em seguida, são apresentadas as teorias relacionadas à difusão de políticas públicas, uma vez que elas serão utilizadas para explicação de fenômenos envolvendo Agências Reguladoras. Por fim, é apresentado o modelo de orquestração, utilizado em conjunto com as teorias de difusão, para compreensão do funcionamento das agências.

\subsection{AGÊNCIAS REGULADORAS E GOVERNANÇA REGULATÓRIA}

\subsubsection{Agências Reguladoras}

O surgimento das Agências Reguladoras não foi um fenômeno somente brasileiro. Nos Estado Unidos, há uma longa tradição desse tipo de instituição, que começou ainda no século XIX com a criação da ICC (Interstate Commerce Commission), em 1887. Desde então, esse tipo de arranjo foi bastante presente nesse país, mas não tinha se tornado tão expressivo ao redor do mundo até a década de 1970.

No período do pós-guerra, o papel do Estado, em grande parte dos países, estava relacionado ao provimento de serviços públicos ao cidadão. Dentre os serviços considerados públicos, estavam aqueles considerados monopólios naturais, devido aos seus altos custos afundados (sunk costs) e impossibilidade de replicação. Em geral, os setores de infraestrutura, como fornecimento de gás canalizado, energia elétrica, transportes e telefonia tinham o monopólio estatal de exploração.

Entretanto, a partir da década de 1970, começaram a surgir críticas bastante contundentes sobre esse modelo. A capacidade de o Estado prover esses serviços foi colocada em xeque, devido à sua incapacidade de dar respostas satisfatórias à sociedade (EVANS, 1993). O Estado não conseguia realizar todas as atividades que se propunha e deveria delegar parte de suas competências à iniciativa privada.

Foi nesse contexto que reformas profundas no papel do Estado começaram a ser feitas nos EUA, especialmente na administração de Ronald 
Reagan, e na administração de Margaret Thatcher no Reino Unido. Em que pese mudanças já tivessem sido iniciadas nos EUA desde a administração de Gerald Ford (DERTHICK, 2001) e no Reino Unido desde a administração de Edward Heath (YOUNG, 2001), as ideias neoliberais de desregulação se difundiram somente posteriormente.

Contribuíram para essa difusão textos como os de Stigler (1971) e de Posner (1974) que, apesar de mostrarem problemas da intervenção estatal na economia, acabaram por acelerar a conversão de um Estado positivo (que provê serviços diretamente ao cidadão), num Estado regulador (que regula a prestação privada dos serviços).

Apesar de o discurso do processo de desregulação ser neoliberal pregar a menor intervenção do Estado, observou-se uma expansão das regras, tanto estatais, como não estatais (VOGEL, 1996) ${ }^{1}$. No caso de telecomunicações, por exemplo, houve a edição de regras para garantir direitos aos consumidores, competição, padrões de qualidade e operação, dentre outros. Dentre as normas não estatais, estão as normas para auditoria de empresas de capital aberto, padrões tecnológicos desenvolvidos por entidades padronizadoras (ISO, UIT, IEEE, etc), normas ambientais, dentre outras.

No Brasil, a história da regulação no Brasil passou por 3 grandes fases (CASTRO, 2013):

- Liberalismo clássico;

- Desenvolvimentismo;

- Reformas pró-mercado.

A primeira fase, do liberalismo, a qual durou até cerca de 1930, é caracterizada pela dominância da exportação do café como matriz econômica do país. As normas legais da época tinham como base o conservadorismo político e econômico, o qual visava proteger a propriedade e os interesses dos produtores rurais, especialmente dos barões do café. Essa proteção era justificada pela alegada vantagem comparativa do Brasil para 0 desenvolvimento de produtos agrários.

\footnotetext{
${ }^{1}$ Apesar de o processo de expansão regulatória ter sido uma consequência não intencional na maioria dos países, tal lógica não é válida para os EUA, onde o aumento da intervenção regulatória federal foi um dos objetivos pretendidos (HORWITZ, 1991).
} 
Entretanto, fatores, como o fim do tráfico de escravos, forçaram mudanças na matriz econômica para a segunda fase, o desenvolvimentismo. Nesse período, as políticas envolviam mais planejamento e execução por parte do Estado, não só uma função de exercer o "poder de polícia" para garantia da propriedade. O Estado deveria então promover o desenvolvimento econômico de maneira ordeira, conforme enunciavam as tendências positivistas. Importante destacar que preocupações distributivistas estavam presentes, 0 que caracteriza uma expansão das funções do Estado até então existentes.

Esse sistema, que promoveu um grande crescimento do PIB brasileiro e a diversificação da economia, teve seu fim com a década perdida entre 1981 e 1990. Com esse cenário interno de crise e uma agenda de reformas prómercado defendidas pelo Banco Mundial e pelo FMI, houve uma alteração na visão sobre o papel do Estado. O Estado deveria então retirar-se dos assuntos econômicos o máximo possível. Isso significou a privatização de diversas empresas em setores nos quais o Estado tinha o monopólio. Como consequência, foram também criadas Agências Reguladoras, tanto para regular monopólios privados com base no bem público, como para criar políticas pró-competição, quando o mercado possibilitava a existência de mais de um competidor.

A implementação desses ideais aconteceu no Brasil especialmente durante o governo de Fernando Henrique Cardoso, com a implementação do Novo Gerencialismo Público, que tinha como objetivo reformar o Estado, dotando-o de maior eficiência e agilidade, capacitando a burocracia e adotando medidas que valorizavam a descentralização e a meritocracia. A criação das Agências Reguladoras estava dentre as medidas de descentralização, com a delegação da prestação dos serviços à iniciativa privada e a adoção de arranjos institucionais que dotavam essas entidades de autonomia e independência.

A busca por autonomia, especialmente em relação ao Governo, estava também relacionada à busca por credibilidade. Com a circulação das ideias sobre a baixa eficiência dos Estados, era necessário que as entidades nascentes fossem dotadas de credibilidade técnica. Tal credibilidade exigia uma desvinculação com a imagem das entidades que estavam sendo 
substituídas. Para isso, especialmente em países que necessitavam de investimentos estrangeiros, o apoio na imagem de credibilidade de consultorias internacionais foi fundamental (AMARAL, 2000; NUNES, 2007).

\subsubsection{Governança Regulatória e Capitalismo Regulatório}

O processo de desregulação espalhou-se pelo mundo, devido à globalização do discurso neoliberal, caracterizando uma nova fase do capitalismo, o Capitalismo Regulatório (LEVI-FAUR, 2005). Esse processo, com todas as suas incongruências, foi comunicado e difundido pelo mundo de acordo com diversos mecanismos, conforme resumido por Levi-Faur (2005) na figura abaixo:

Figura 1 - Difusão das reformas regulatórias: top-down, bottom-up, ou horizontal?

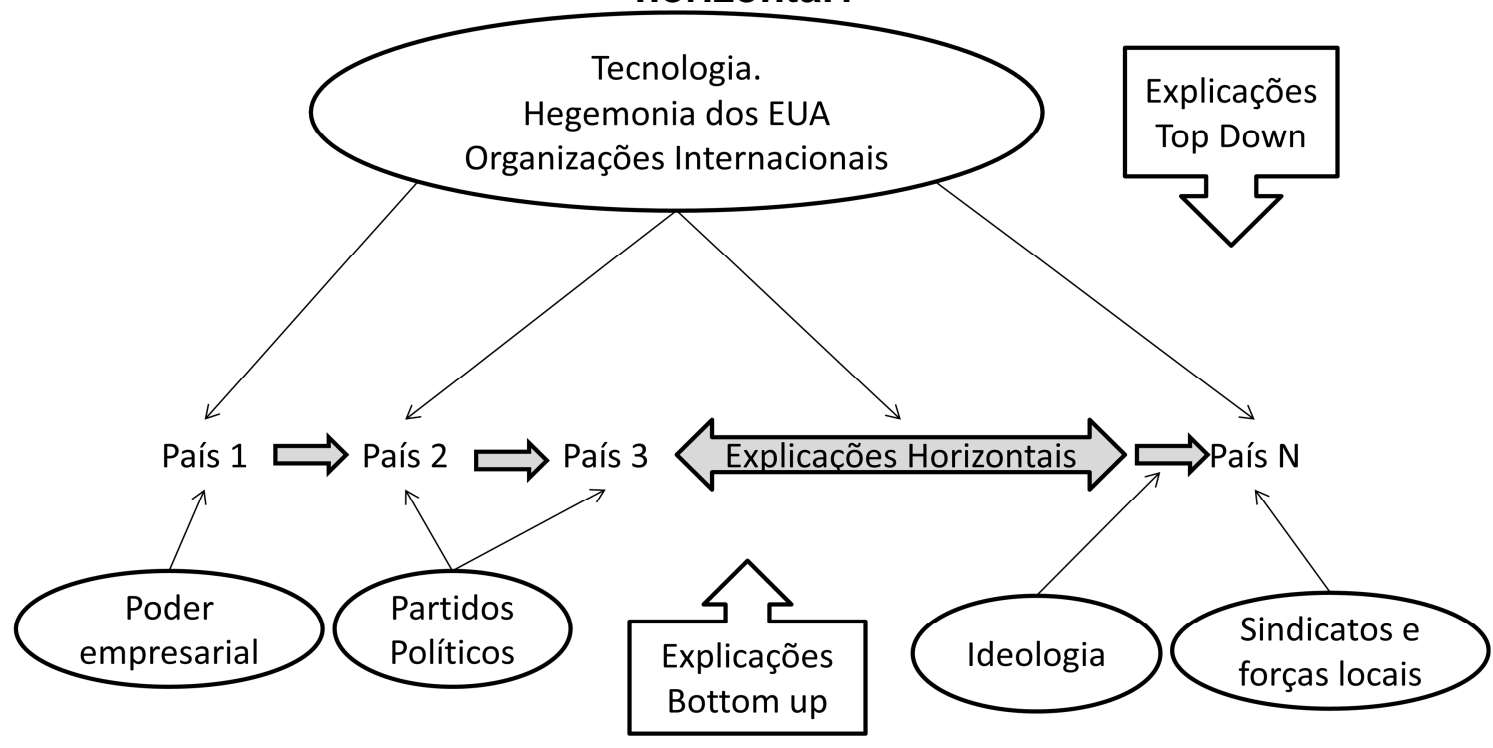

Fonte: Levi Faur (2005)

Os diversos mecanismos de difusão da reforma regulatória, sob formatos top-down, bottom-up, e horizontal refletem o grau de interdependência entre diversos tipos de organização e instituições. O ecossistema institucional tornou-se mais complexo, bem como as fontes de influência que possibilitariam outras formas de captura, além da captura pelo mercado, causada pela assimetria de informação, conforme formulado por Stigler (1971).

Quando o conceito de difusão é aplicado não só às reformas regulatórias, mas à própria atuação das Agências Reguladoras, começa-se a questionar sobre sua independência. $O$ arranjo institucional das agências e sua governança pressupõem meios para mitigar influências externas, entretanto regulamentações internacionais, necessidade de credibilidade, rankings, 
empréstimos condicionados a determinados comportamentos, dentre outros mecanismos podem ser utilizados para induzir comportamentos dos Estados e de suas entidades (BRAITHWAITE, 2008). Importante, então, compreender o posicionamento do regulador ante um ecossistema de instituições nacionais e internacionais.

Num contexto de globalização e expansão do capitalismo regulatório (LEVI-FAUR 2005, 2011), uma corrente de estudos se dedica a compreender o funcionamento das Agências Reguladoras sob a influência de diversos mecanismos de governança, como redes de reguladores e orquestração (ABBOTT, 2015).

Tais estudos baseiam-se muito no neoinstitucionalismo e no isomorfismo institucional, especialmente no clássico texto de DiMaggio e Powell (1983): A gaiola de ferro revisitada: Isomorfismo institucional e racionalidade coletiva em campos organizacionais ${ }^{2}$. Para DiMaggio e Powell, ao contrário do que previa Weber, a homogeneização das instituições em direção à burocratização não se deve somente à busca pela eficiência em um ambiente competitivo, mas sim a um processo de isomorfismo, quem nem sempre visa a eficiência. Para eles, esse isomorfismo pode acontecer de acordo com 3 mecanismos: isomorfismo coercivo, isomorfismo mimético e isomorfismo normativo.

No caso do arranjo institucional de Agências Reguladoras, diversos estudos utilizam esses mecanismos para compreender a expansão do capitalismo regulatório (JARVIS, 2014) e que deu origem ao Estado Regulatório. Para se compreender os mecanismos de governança regulatória, há que se entender quais características dão a desejada autonomia às Agências Reguladoras, características essas que podem ser divididas como formais e factuais, conforme classificação de GILLARDI e MAGGETTI (2011):

\footnotetext{
${ }^{2}$ Tradução livre.
} 


\begin{tabular}{|c|c|c|}
\hline \multirow{15}{*}{ Formais } & \multirow{6}{*}{ Diretoria } & Término do mandato \\
\hline & & Procedimento de indicação \\
\hline & & Procedimento de demissão \\
\hline & & Renovação da indicação \\
\hline & & Compatibilidade com outros trabalhos \\
\hline & & Requisição formal de independência \\
\hline & \multirow{3}{*}{$\begin{array}{l}\text { Relação com políticos } \\
\text { eleitos }\end{array}$} & Independência formalmente estabelecida \\
\hline & & Obrigações formais \\
\hline & & Reviravolta de decisões \\
\hline & \multirow{3}{*}{ Organização e finanças } & Fonte de recursos \\
\hline & & Organização interna da agência \\
\hline & & Controle sobre os recursos humanos \\
\hline & \multirow{3}{*}{ Competências Regulatórias } & Regulamentação \\
\hline & & Monitoramento \\
\hline & & Sancionamento \\
\hline \multirow{12}{*}{ Factuais } & \multirow{7}{*}{ Dos políticos } & Frequência do "revolving door" \\
\hline & & Frequência dos contatos \\
\hline & & Influência no orçamento \\
\hline & & Influência na organização interna \\
\hline & & Partidarismo das nominações \\
\hline & & Vulnerabilidade política \\
\hline & & Influência externa na regulação \\
\hline & \multirow{5}{*}{ Dos regulados } & Frequência do "revolving door" \\
\hline & & Frequência dos contatos \\
\hline & & Influência no orçamento \\
\hline & & Influência na organização interna \\
\hline & & Atuação profissional dos diretores \\
\hline
\end{tabular}

Fonte: Gilardi e Maggetti (2011).

Como se pode perceber, o que geralmente é avaliado é a independência em relação aos agentes regulados e em relação ao governo. No presente estudo, é buscada a introdução de novos agentes, especialmente fora do contexto nacional, para investigação de seu papel na regulação nacional. 
No contexto europeu, onde existe uma grande cooperação entre os diversos países por meio da União Europeia e de redes regulatórias, a relevância do papel das redes de reguladores já foi identificada (EGEBERG e TRONDAL, 2009) e é bastante estudada. Além disso, foi percebida a diferença de atuação e influência de acordo com a "capacidade administrativa" e "experiência" (MARTENS, 2008) de cada um dos países. Porém, no caso brasileiro, poucas são as referências que estudam a influência de agentes internacionais.

\subsection{TEORIA DE DIFUSÃO DE POLÍTICAS PÚBLICAS}

A teoria de difusão de políticas públicas já se consolidou como uma teoria que explica diversos fenômenos relativos ao agendamento e escolha de políticas públicas. Inicialmente focado em casos de difusão entre entidades subnacionais (WALKER, 1969), como estados e municípios, vários estudos tiveram como objeto de pesquisa também a difusão entre Estados nacionais.

O desenvolvimento da teoria de difusão focou-se principalmente em identificar fatores que pudessem facilitar a difusão e em mecanismos que a propiciam. Esses fatores classificam-se como internos (características endógenas) e externos (características exógenas). Apenas a título exemplificativo, pode-se citar alguns fatores, tais como proximidade geográfica, existência de comunidades epistêmicas, competição entre as unidades em que a difusão ocorre, dentre outros (SHIRPAN, 2012; SIMMONS, DOBBIN e GARRETT, 2007). Quanto aos mecanismos destacam-se o isomorfismo (RADAELLI, 2000), o aprendizado (DUNLOP, 2009) e a coerção (HENISZ, ZELNER e GUILLÉN, 2005).

Apesar dessas diversas nomenclaturas, há certo consenso sobre o que é difusão internacional de políticas públicas, assim descrito por GILARDI (2012):

Difusão internacional de políticas públicas ocorre quando decisões governamentais sobre políticas públicas em um dado país são sistematicamente condicionadas por decisões anteriores de outros países. $^{3}$

Desta forma, o que une todas essas diferentes abordagens é o fator temporal, ou seja, como uma mesma política é adotada ao longo do tempo por

\footnotetext{
${ }^{3}$ Tradução livre.
} 
diversas unidades e como a simultaneidade na ocorrência de fatores internos e externos se reflete na difusão.

Entretanto, a correlação direta entre os fatores e a adoção de uma política por determinada unidade não é suficiente para se estabelecer uma relação causal. A decisão de uma dessas unidades, por vezes, pode estar condicionada a uma variável interveniente oculta (Problema de Galton), que é, de fato, a responsável pela difusão (GILARDI, 2012). Essa variável seria a articulação dos agentes por meio de aprendizado, interdependência, coerção, normas comuns, unanimidades ou imitação simbólica (BRAUN, 2006).

Por esta razão, é importante conhecer a fundo o funcionamento dos mecanismos de difusão, de forma a não se atribuir erroneamente as causas de um fenômeno de difusão. Essa necessidade induz a utilização de métodos nos quais é possível conhecer mais detalhadamente as características do fenômeno, como estudos de caso, análise de histórico de eventos (event history analysis) e rastreamento de processos (process tracing).

Além disso, nos últimos anos, há que se destacar o papel da internet na criação de uma nova arena para discussão e troca de experiências. Essa nova arena facilita o contato dos especialistas e dá visibilidade às populações das ações de outros países, criando constrangimentos antes inexistentes. Dolowitz e Marsh (1996) reconhecem a evolução das comunicações como um fator acelerador da difusão de políticas públicas desde o fim da $2^{\underline{a}}$ Guerra Mundial.

Ademais, pode-se afirmar também que o incremento da difusão foi fomentado pelas agências setoriais da ONU, cuja criação data também do pósguerra. Esses fóruns servem de arenas em que experiências são trocadas, informação é consolidada para formação de rankings e convergências podem ser atingidas de maneira mais fácil. São locais em que a influência de países centrais sobre países periféricos pode ocorrer de forma mais potencializada, diminuindo custos transacionais de disseminação de informação.

O processo de globalização e harmonização de políticas em nível internacional e muitas vezes de coerção por organismos de financiamento pode gerar uma transferência de arranjos e políticas advindas de países líderes em cada setor específico (HENISZ, ZELNER e GUILLÉN, 2005). Este fato foi também percebido por Dolowitz e Marsh (1996), que reconheceram a 
importância de atores externos ao governo, colocando ênfase na pressão que governos estrangeiros, organizações internacionais e empresas transnacionais para adoção de políticas públicas.

Essa expansão de políticas e de mercados torna-se ainda mais importante num momento de crise financeira em que a abertura de novos mercados pode ser vista como caminho para retomada do crescimento econômico, uma vez que o a expansão dos serviços regulados está associado ao crescimento da produtividade e do PIB (CZERNICH, FALK e KRETSCHMER, 2009).

Assim, apesar de os setores estudados não terem organismos centrais internacionais que sejam hierarquicamente superiores às Agências Reguladoras nacionais, há mecanismos que propiciam essa interconexão. Essa interconexão advém da necessidade de desenvolvimento de regulamentações que garantam a harmonia e a existência padrões com escala global. Ou seja, apesar de as entidades parte dos setores estudados serem descoordenadas (sem um organismo central hierarquicamente superior), elas são interconectadas por meio de agências especializadas da ONU.

Outra variável que pode ser utilizada na busca de relações causais e padrões é a dinamicidade no uso de tecnologia por cada setor. Para os setores com rápidas transições ou que são submetidos a mudanças abruptas de tecnologia (banda larga, por exemplo) a ausência de parâmetros internos para o empreendimento de políticas públicas faz que os agentes estatais busquem exemplos em outros países (DOLOWITZ e MARSH, 1996). Assim, para reduzir a incerteza sobre o que fazer em temas tão técnicos, muitos governos adotam políticas implementadas em outros países sem, muitas vezes, dar a devida importância às características peculiares de cada nação.

Entretanto, há setores em que a dinamicidade tecnológica é menor e há outros valores mais importantes, como é o caso da segurança operacional em aviação civil. Nessa situação, é possível esperar até que bons resultados advindos de experiências de outros países possam surgir, as quais serão entendidas de acordo com os valores e paradigmas do decisor/formulador da política. Dunlop (2009) descreve essa componente cognitiva da transferência, na qual as preferências e valores dos decisores filtram o aprendizado de 
acordo com suas visões ou seus interesses, evidenciando o uso estratégico da transferência de políticas públicas.

No Brasil, vários estudos já utilizaram modelos de difusão de políticas públicas para explicar fenômenos como programas de transferências de renda (COÊLHO, 2012), orçamento participativo (WAMPLER, 2007; SPADA, 2010), e políticas sociais (SUGIYAMA, 2007). Entretanto, nenhum desses estudos tratou do caso de políticas de telecomunicações e de uso do espectro, que são políticas nacionais. Por esta razão, para o objeto de estudo tratado, a difusão tem que ser compreendida como um fenômeno global, o que se diferencia da maioria dos estudos sobre difusão de políticas públicas produzidos no Brasil.

Desta forma, as bases teóricas e conceituais das teorias de difusão de políticas públicas são úteis para testar as hipóteses explicativas do problema de pesquisa, rapidamente descritos na introdução e mais bem detalhados mais adiante neste estudo.

\subsection{MODELO DE ORQUESTRAÇÃO}

\subsubsection{Introdução ao tema}

O conceito e o modelo de orquestração utilizados neste trabalho são baseados nos argumentos trazidos pelo livro "Organizações Internacionais como Orquestradores" 4 (ABBOTT, 2015). Esse livro aplica o modelo (mais bem detalhado adiante) para diversas situações e casos, colocando as Organizações Internacionais na condição de orquestradores. Os diversos capítulos do livro aplicam o modelo para variados regimes internacionais, os quais envolvem comércio, finanças, meio ambiente, saúde, paz e desenvolvimento social.

Há que se observar que a governança no regime internacional para o setor de telecomunicações não foi tratada no referido livro ${ }^{5}$. Vale, então, mencionar que para fazer uso desse conceito neste trabalho, algumas considerações devem ser feitas, as quais serão descritas após a apresentação do modelo.

\footnotetext{
${ }^{4}$ Tradução livre.

${ }^{5}$ No capítulo 2 do livro é tratado o caso de redes regulatórias transgovernamentais na Europa, incluindo o caso de telecomunicações. No entanto, não é tratado o ecossistema setorial inteiro, com outros atores como fabricantes e prestadoras, nem como é a governança em escala global.
} 


\subsubsection{Conceito}

O modelo de orquestração é derivado do modelo principal-agente. No modelo de principal-agente, alguns fatores são necessários para que os objetivos planejados pelo principal possam ser atingidos por meio do agente (NOLL, 1989):

- Em qual extensão são os conflitos de interesse entre agente e principal;

- Custos e precisão dos métodos para que o principal monitore a performance do agente;

- O poder dos mecanismos de enforcement do principal para redirecionar os incentivos do agente.

Pela dificuldade de se obter todas essas características em situações práticas, a introdução de algum intermediário pode ser o mecanismo ideal para atendimento dos interesses tanto do principal, quanto do agente. A introdução desse intermediário é a proposta do modelo de orquestração. Nesse modelo, os atores também têm suas denominações alteradas para serem introduzidas no novo modelo, o que pode ser representado na figura abaixo:

Figura 2 - Modelo principal-agente e Modelo de orquestração

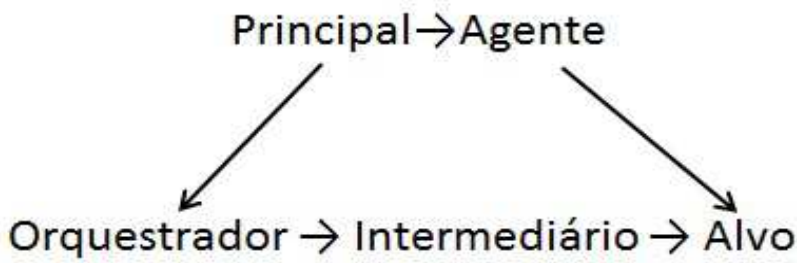

Fonte: elaborado pelo autor.

Com essa modelagem, a orquestração, como modo de governança, é indireta e soft. Indireta devido a existência do intermediário e soft porque a introdução do intermediário ocorre sem um controle hierárquico do orquestrador sobre esse ator.

Com isso, o modelo de orquestração é diferente de outros modos de governança, conforme resumido na tabela abaixo, extraída de Abbott (2015):

Figura 3 - Quatro modos de governança.

\begin{tabular}{|l|l|l|}
\hline & Direto & Indireto \\
\hline Hard & Hierarquia & Delegação \\
\hline Soft & Colaboração & Orquestração \\
\hline
\end{tabular}

Fonte: Abbott (2015). 


\subsubsection{Premissas do modelo de orquestração}

O modelo de orquestração é baseado em quatro premissas: suposição de orquestração, suposição de busca de objetivos, suposição de capacidades complementares e suposição de objetivos correlacionados.

A suposição de orquestração está relacionada à relação entre 0 orquestrador e o intermediário, que é supostamente indireta e soft. Para isso, o desafio do orquestrador é encontrar objetivos comuns com o intermediário. Além disso, comparado com o modelo principal-agente, este modelo dá mais ênfase nos elos institucionais e de confiança entre orquestrador e intermediário.

A suposição de busca de objetivos baseia a decisão dos agentes em engajarem-se numa orquestração com o objetivo de atingirem seus objetivos e interesses. Como é uma relação não mandatória, ela só será possível se tanto o intermediário como o orquestrador perceberem benefício nessa relação para 0 atingimento de seus objetivos.

A suposição de capacidades complementares baseia a decisão do orquestrador de buscar algum intermediário que detenha capacidades que ele mesmo não tenha. Nesse sentido, orquestrador e intermediário são mutuamente dependentes, o que também distancia esse modelo do modelo principal-agente, em que a dependência é basicamente assimétrica e unidirecional.

A suposição de objetivos complementares está relacionada à proximidade ou, ao menos, compatibilidade entre os objetivos do orquestrador e do intermediário. Isso não significa que a relação entre os dois atores será sempre harmônica, pois diversos conflitos podem surgir, devido a prioridades distintas, valores e ideologias diferentes, dentre outros fatores.

\subsubsection{Hipóteses gerais para orquestração}

O modelo de orquestração estabelece ainda sob quais condições algum ator irá engajar-se nesse modo de governança. Essas hipóteses estão resumidas na tabela abaixo: 
Tabela 2 - Hipóteses para orquestração.

\begin{tabular}{|c|c|}
\hline \multicolumn{2}{|r|}{ Os atores tendem a orquestrar, quando: } \\
\hline $\begin{array}{l}\text { Capacidades do } \\
\text { orquestrador }\end{array}$ & $\begin{array}{l}\text { Aos orquestradores faltam certas capacidades para atingir } \\
\text { seus objetivos por meio de outros modos de governança. }\end{array}$ \\
\hline $\begin{array}{l}\text { Disponibilidade de } \\
\text { intermediários }\end{array}$ & $\begin{array}{l}\text { Disponibilidade de intermediários com } \\
\text { correlacionados e capacidades complementares. }\end{array}$ \\
\hline $\begin{array}{l}\text { Focalidade do } \\
\text { orquestrador }\end{array}$ & Eles são focais dentro da área temática. \\
\hline $\begin{array}{l}\text { Empreendedorismo } \\
\text { do orquestrador }\end{array}$ & $\begin{array}{l}\text { Sua estrutura organizacional e cultura encorajam o } \\
\text { empreendedorismo de políticas públicas. }\end{array}$ \\
\hline
\end{tabular}

Os atores tendem a buscar métodos de governança não hierárquicos, como a orquestração, quando Ihes falta alguma capacidade que o possibilite fazê-lo de maneira hierárquica. Seria pouco provável que um ator fizesse uso da orquestração se ele tivesse autoridade para fazer regulamentações (competência regulatória), recursos suficientes para implementar suas regras (capacidade operacional) e legitimidade ante os alvos. No outro extremo, se algum ator não possuir competência regulatória, capacidade operacional ou legitimidade, ele não terá nada a oferecer ao intermediário. Entretanto, muitos atores podem estar entre esses extremos.

A disponibilidade de intermediários é outra importante hipótese para orquestração. Os orquestradores não têm meios de forçar outros atores a participar na governança. Eles (orquestradores) buscam, assim, outros atores com objetivos correlacionados e com capacidades complementares. Importante observar que a disponibilidade pode ser factual ou potencial e os orquestradores podem usar seu poder para dar assistência, apoiar na criação de intermediários ou modificar as organizações existentes. Além disso, a disponibilidade de intermediários pode afetar a posição de barganha de cada um dos atores. Se a disponibilidade de intermediários for pequena, o orquestrador estará numa posição mais fraca, entretanto, se os candidatos a intermediários forem muitos, o orquestrador poderá melhor negociar as condições de colaboração. 
A hipótese de focalidade refere-se à liderança do orquestrador no setor, o quão central, singular e incontestável ela é. No mundo real, entretanto, a focalidade tem muitos graus, mas quanto maior for essa característica do orquestrador, maior será a sua capacidade de arregimentar intermediários e reforçar sua posição de liderança.

A cultura e a estrutura organizacional também importam na tendência de um ator engajar-se numa orquestração. Assim, uma cultura e estruturas institucionais que facilitam a interação possibilitam regimes em que haja mais interação, troca e colaboração. Da mesma maneira, uma estrutura e uma cultura que premiam ação unilateral, fechamento, continuidade e seguimento estrito das regras desincentivam ações colaborativas, como exige o modelo. Tais características podem ser observadas em elementos como descentralização administrativa, processo informal de tomada de decisão, as quais dão a pessoas empreendedoras oportunidades de realizar interações inovadoras.

\subsubsection{Adaptações necessárias para aplicação no caso concreto}

No modelo original, os regimes são descritos com foco nos objetivos dos organismos internacionais, ou seja, o foco está no orquestrador do modelo, em suas características e capacidades. No presente estudo, no entanto, o foco é diferente.

O foco neste estudo será dado no alvo do modelo (Agência Reguladora) e nos diversos agentes que estão tentando influenciá-lo. Assim, será importante descrever as características e capacidades desses agentes, tentando-se identificar quais dessas influências são mais relevantes e o porquê disso. Desta forma, a colocação do organismo internacional como orquestrador não é uma premissa para este trabalho, mas sim algo a ser verificado e problematizado, o que leva à possibilidade de a função de orquestrador ser exercida por outros agentes.

Além disso, após serem apresentadas as características do objeto de estudo, algumas hipóteses específicas serão introduzidas. 


\section{DESCRIÇÃO DO ARRANJO INSTITUCIONAL DA ÁREA DE RADIOCOMUNICAÇÕES}

\subsection{O SETOR DE TELECOMUNICAÇÕES}

O setor de telecomunicações é um setor de infraestrutura. Por essa razão, assim como energia, aviação civil e transportes, é um setor com intensivo uso de capital e com custos afundados bastante significativos. Essa característica fez com que esse setor fosse compreendido por grande parte dos países do mundo como um monopólio natural e que, por essa natureza, deveria ser explorado pelo Estado.

Esse cenário começou a mudar a partir anos 1970, com a expansão de políticas neoliberais e a transformação de um Estado Executor em um Estado Regulador. Tais alterações possibilitaram a privatização de vários desses setores, que estariam abertos à competição plena ou regulados por agentes estatais em casos com permanência de um monopólio privado ou de um oligopólio ${ }^{6}$.

Nesse processo de abertura de mercado, muitos desses setores tiveram uma importante participação de capital internacional, possibilitando a existência de grandes conglomerados econômicos transnacionais. No caso do setor de telecomunicações, essa participação é relevante no que se refere às prestadoras de serviço, mas também é especialmente importante nos desenvolvedores de solução e tecnologia (fabricantes).

Os custos para desenvolvimento de equipamentos são muito altos, o que dificulta a participação de entidades que não têm escala global. Uma maneira fácil de identificar essa característica é perceber que os telefones celulares são praticamente todos produzidos por um reduzido número de fabricantes estrangeiros, mesmo que manufaturados no Brasil, um país com significativa escala de produção. Assim, essas entidades exercem um papel decisivo na definição das escolhas a serem tomadas pelos governos, tanto na escolha de tecnologias que serão utilizadas em determinado país, quanto das políticas, uma vez que as soluções para os problemas da sociedade partem dessas companhias.

\footnotetext{
${ }^{6}$ Nos Estados Unidos, a história da regulação é diferente. Vide Horwitz (1991).
} 
Apesar de existirem diversos fabricantes pelo mundo, o que denotaria uma grande competição e, consequentemente, menor poder de influência, essas companhias são articuladas, uma vez que grande parte de seus objetivos são comuns. Dessa articulação surgem grupos formais, como o 3GPP (3rd Generation Partnership Project), inclusive no âmbito nacional, como a ABINEE (Associação Brasileira da Indústria Elétrica e Eletrônica). Fato bastante similar ocorre com as prestadoras de serviço, que, em nível mundial, criaram a GSMA (em que pese ela também tenha fabricantes e outras entidades associadas) e, no âmbito nacional a Telebrasil.

Do ponto de vista estatal, a articulação dos Estados em escala global ocorre por meio de uma agência da ONU específica para questões de telecomunicações, a UIT (União Internacional de Telecomunicações). Além disso, existem diversos outros fóruns regionais, como a Citel (Comissão Interamericana de Telecomunicações, parte da OEA (Organização dos Estados Americanos), Regulatel (Foro Latinoamericano de Entes Reguladores de Telecomunicaciones), e comissões temáticas no âmbito do Subgrupo de Trabalho 1 - Comunicações do Mercosul.

Por essas razões, o setor de telecomunicações é um setor com muito intercâmbio de informações sobre estatísticas e ações regulatórias, o que pode contribuir para uma transferência mais fácil de políticas públicas. O setor de telecomunicações é caracterizado também por rápidas mudanças tecnológicas, ponto em que se difere de vários outros setores de infraestrutura.

Durante um tempo considerável, o setor apresentou taxas de crescimento consideráveis, o que é relativamente raro de ser visto em outros setores de infraestrutura. Uma das possíveis explicações para esse fenômeno, e que diferencia o setor de telecomunicações de outros setores de infraestrutura, é a constante introdução de inovações.

Devido a essa característica, muitos países introduziram políticas voltadas para desenvolvimento tecnológico em telecomunicações. Como exemplo, pode-se citar a própria criação do Protocolo IP (Internet Protocol), a qual foi patrocinada pelo Departamento de Estado Americano (LEINER, 2009).

O domínio tecnológico distinto em cada um dos países criou basicamente três polos de tecnologia: América do Norte, especialmente nos 
Estados Unidos, Europa e Ásia, historicamente no Japão e mais recentemente na Coreia do Sul e na China ${ }^{7}$. A América Latina, incluindo o Brasil, ocupa posição secundária, caracterizando-se mais como consumidor de tecnologia, do que como produtor.

Durante muitos anos, a competição internacional pelo desenvolvimento tecnológico não se refletiu nos planos domésticos de prestação de serviço. A maioria dos países adotava a prestação de serviços de telecomunicações como uma prerrogativa do Estado e os serviços eram prestados por um monopólio estatal, salvo importantes exceções, como nos EUA, em que havia um monopólio privado regulado.

O relativo afastamento do Estado na prestação de serviços e busca pelo barateamento de tais atividades fez com que os requisitos de compra pelas empresas, não mais estatais, ampliasse a competição internacional e cada vez mais os equipamentos deveriam ser harmonizados no sentido ter ganhos de escala e compatibilidade.

Outra questão relevante é a necessidade de padronização para se garantir comunicações internacionais. Esse objetivo é algo buscado desde há muito tempo, uma vez que, para que haja comunicação, os interlocutores têm que utilizar o mesmo "código", sob a pena de não haver compreensão. A necessidade de desenvolvimento desses "códigos" por meio de padrões e protocolos, em conjunto com a necessidade de coordenação de radiofrequências, justifica a existência de organismos internacionais, como a UIT (União Internacional de Telecomunicações), que faz parte do sistema ONU, bem como outros fóruns privados.

\subsubsection{O desenvolvimento tecnológico do setor de telecomunicações no} Brasil

O Brasil, devido a sua população e sua extensão territorial, é um importante mercado de telecomunicações no cenário mundial. Ao final de 2014, o Brasil era o 5 maior mercado mundial em número de acessos móveis, ficando atrás somente de China, Índia, Indonésia e Estados Unidos. ${ }^{8}$

Essa é uma das razões de o setor ter atraído investimentos nacionais e internacionais, com grupos econômicos diversos atuando nas mais diversas

\footnotetext{
${ }^{7}$ Como será visto mais adiante, a UIT adota divisão territorial que segue essa lógica.

${ }^{8}$ Fonte: http://www.itu.int/en/ITU-D/Statistics/Pages/stat/default.aspx
} 
plataformas tecnológicas, como cabos submarinos, comunicação via satélite, comunicação fixa, móvel e acesso a Internet. Esses investimentos proporcionaram um crescimento de receitas superiores ao crescimento do PIB desde a privatização, conforme mostra o estudo "O desempenho do setor de telecomunicações no Brasil - Séries Temporais 2015", da Associação Brasileira de Telecomunicações ${ }^{9}$ :

Figura 4 - Comparação de crescimento entre serviços de informação e PIB no Brasil.

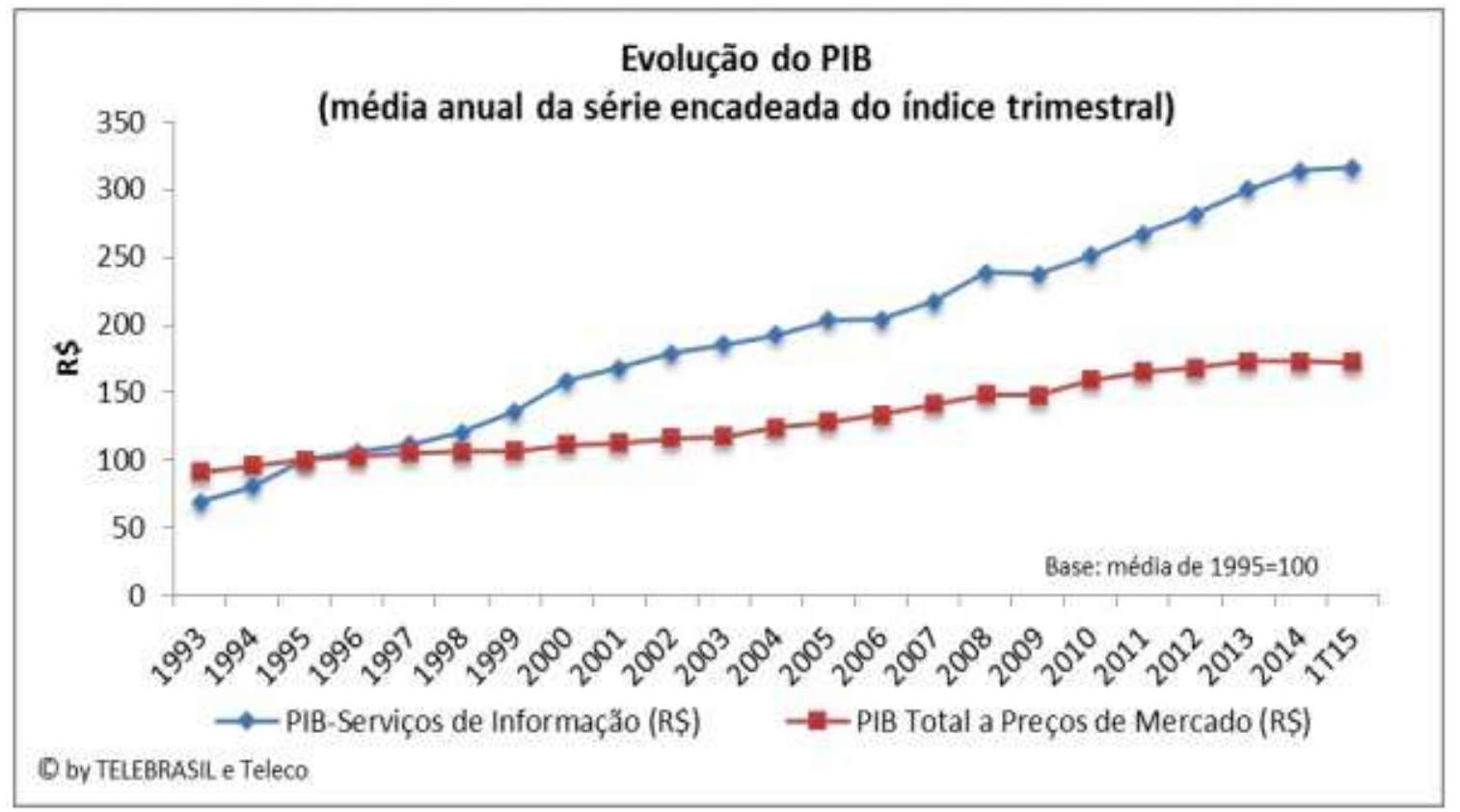

Fonte: O desempenho do setor de telecomunicações no Brasil - Séries Temporais $2015^{10}$.

Devido a essas altas taxas de crescimento, o setor atraiu bastante investimento na prestação de serviços após a privatização do sistema Telebrás no final da década de 1990. Entretanto, o país, por diversas razões, não desenvolveu conglomerados econômicos ou tecnológicos no cenário mundial, mantendo-se em posição intermediária nos rankings de desenvolvimento tecnológico ${ }^{11}$, sendo mais importador, do que produtor de tecnologia, conforme relatório do BNDES ${ }^{12}$ :

\footnotetext{
${ }^{9}$ Fonte: http://www.telebrasil.org.br/panorama-do-setor/desempenho-do-setor

${ }^{10}$ Fonte: http://www.telebrasil.org.br/panorama-do-setor/desempenho-do-setor

${ }^{11}$ http://www.senado.gov.br/noticias/jornal/emdiscussao/Upload/201101\%20\%20fevereiro/pdf/em\%20discuss\%C3\%A3o!_fevereiro_internet.pdf

${ }^{12}$ BNDES, Complexo eletrônico: A evolução recente e os desafios para o setor e para a atuação do BNDES, disponível em
} 
Figura 5 - Balança comercial de equipamentos de telecomunicações no Brasil entre 2002 e 2011.

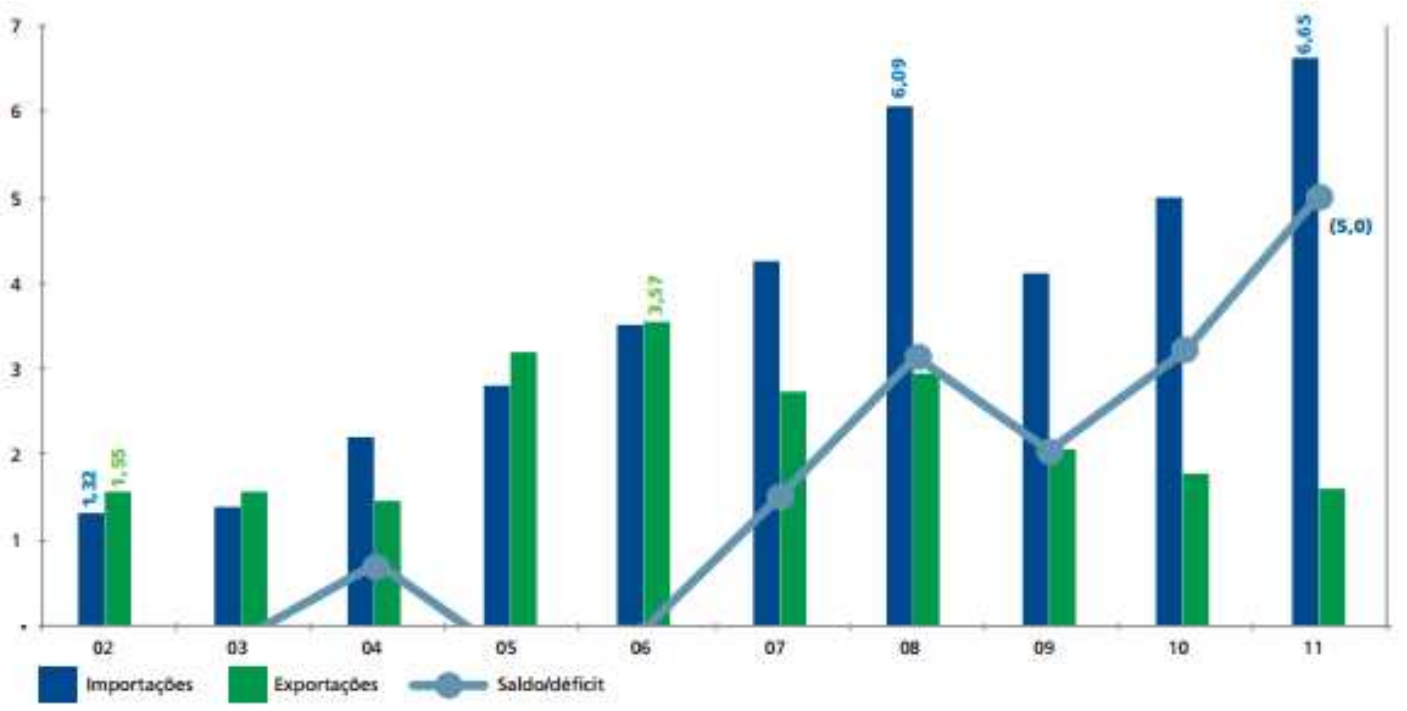

Fonte: BNDES ${ }^{13}$ :

Uma explicação pode ser encontrada no mesmo relatório ${ }^{14}$ :

Em equipamentos para telecomunicações, o crescimento do déficit se associa a duas frentes. Em uma, os seguintes fatores enfraqueceram de maneira sistemática as empresas com base tecnológica no país: (i) a perda do principal comprador (Telebrás), a concentração dos clientes (operadoras) que praticam compras globais, e (ii) o porte relativamente pequeno das empresas nacionais com consequente incapacidade de realizar investimentos em inovação em compasso com os concorrentes mundiais. Na outra frente, a consolidação dos fornecedores mundiais associada às condições macroeconômicas brasileiras e à competição agressiva de empresas chinesas desencadeou uma onda de desinvestimentos fabris de multinacionais, que passaram a focar mais em serviços em suas operações brasileiras.

https://web.bndes.gov.br/bib/jspui/bitstream/1408/937/4/Complexo\%20Eletronico_\%20a\%20evolucao $\% 20$ recente_final.pdf

${ }^{13}$ BNDES, Complexo eletrônico: A evolução recente e os desafios para o setor e para a atuação do BNDES, disponível

em https://web.bndes.gov.br/bib/jspui/bitstream/1408/937/4/Complexo\%20Eletronico_\%20a\%20evolucao \%20recente_final.pdf

${ }^{14}$ BNDES, Ob. cit. p. 72 


\subsubsection{O sistema setorial de inovação de telecomunicações brasileiro}

O sistema setorial de inovação do setor de telecomunicações foi instituído no contexto da privatização do sistema Telebrás, no final da década de 1990.

O tema de desenvolvimento tecnológico estava presente logo no art. $2^{\circ}$ da Lei 9.472/97, Lei Geral de Telecomunicações - LGT:

Art. $2^{\circ} \mathrm{O}$ Poder Público tem o dever de:

$V$ - criar oportunidades de investimento e estimular $o$ desenvolvimento tecnológico e industrial, em ambiente competitivo;" Art. 127. A disciplina da exploração dos serviços no regime privado terá por objetivo viabilizar o cumprimento das leis, em especial das relativas às telecomunicações, à ordem econômica e aos direitos dos consumidores, destinando-se a garantir:

$I X$ - o desenvolvimento tecnológico e industrial do setor;

Assim, o Estado, no desenvolvimento da política pública relativa à prestação dos serviços de telecomunicações, atribuiu-se o papel de estimulador do desenvolvimento tecnológico do setor. Essa preocupação foi um pouco mais detalhada na própria Lei, como vemos nos artigos. 76-78:

Art. 76. As empresas prestadoras de serviços e os fabricantes de produtos de telecomunicações que investirem em projetos de pesquisa e desenvolvimento no Brasil, na área de telecomunicações, obterão incentivos nas condições fixadas em lei.

Art. 77. O Poder Executivo encaminhará ao Congresso Nacional, no prazo de cento e vinte dias da publicação desta Lei, mensagem de criação de um fundo para o desenvolvimento tecnológico das telecomunicações brasileiras, com o objetivo de estimular a pesquisa e o desenvolvimento de novas tecnologias, incentivar a capacitação dos recursos humanos, fomentar a geração de empregos $e$ promover 0 acesso de pequenas e médias empresas a recursos de capital, de modo a ampliar a competição na indústria de telecomunicações. 
Art. 78. A fabricação e o desenvolvimento no País de produtos de telecomunicações serão estimulados mediante adoção de instrumentos de política creditícia, fiscal e aduaneira.

Como se pode perceber, o Estado já apontava os mecanismos que seriam utilizados para o desenvolvimento da indústria de telecomunicações, quais sejam a criação de um fundo e a utilização de instrumentos creditícios, fiscais e aduaneiros.

Restava, no entanto, dar tratamento aos centros de pesquisa também vinculados ao Estado. Para o setor de telecomunicações, essa entidade era o CPqD (Centro de Pesquisa e Desenvolvimento), também parte do Sistema Telebrás. Sobre esse centro, a LGT dispôs o seguinte:

Art. 190. Na reestruturação e desestatização da Telecomunicações Brasileiras S.A. - TELEBRÁS deverão ser previstos mecanismos que assegurem a preservação da capacidade em pesquisa $e$ desenvolvimento tecnológico existente na empresa.

Parágrafo único. Para o cumprimento do disposto no caput, fica o Poder Executivo autorizado a criar entidade, que incorporará o Centro de Pesquisa e Desenvolvimento da TELEBRÁs, sob uma das seguintes formas:

I - empresa estatal de economia mista ou não, inclusive por meio da cisão a que se refere o inciso I do artigo anterior;

II - fundação governamental, pública ou privada.

Houve preocupação, portanto, com a preservação da capacidade em pesquisa e desenvolvimento tecnológico existente na estatal, por meio de uma adaptação da natureza do $\mathrm{CPqD}$, não mais vinculado ao Sistema Telebrás.

$\mathrm{O} C P q D$ foi então transformado em uma fundação privada que teria como legado todo o desenvolvimento e capacidade intelectual desenvolvidos durante a fase em que o setor de telecomunicações esteve estreitamente ligado ao Estado.

No cenário daquela época (final dos anos 1990), o papel do Estado foi alterado, passando de um prestador de serviços e desenvolvedor das tecnologias, para um regulador e um incentivador das atividades em âmbito privado, incluindo prestação de serviços e desenvolvimento tecnológico. 
No entanto, o objetivo da privatização do setor de telecomunicações era oferecer um serviço melhor à população, considerado bastante precário durante a década de 1990. Esse problema foi atacado diretamente, o que nem sempre é a melhor estratégia se não se identifica muito claramente a "causa". Se a causa não for atacada, a política não se torna sustentável e tem-se a impressão de que as ações empreendidas não surtiram o efeito esperado ou foram insuficientes. No caso da privatização do setor de telecomunicações, pelo que se percebe da exposição de motivos da Lei Geral de Telecomunicações, a "causa" identificada foi a ineficiência do Estado na prestação de serviços e, desta forma, a privatização deveria resolver esta questão.

Passados quinze anos da liberalização do setor, ainda existem diversas queixas quanto à qualidade do serviço, demonstrada pelas recentes ações da Anatel de suspensão de vendas. Apesar disso, os indicadores de penetração mostram uma expressiva melhoria na prestação e no alcance dos serviços.

Porém, essas observações nos fazem refletir se a "causa" do problema estaria sendo atacada, o que leva a uma questão intrigante: poderia a "causa" da baixa qualidade do serviço prestado no Brasil ser a mesma no final da década de 1990 e estar relacionada ao desenvolvimento tecnológico do país? Essa questão será mais bem descrita e detalhada em capítulos posteriores.

\subsubsection{Criação e atuação do Funttel}

Com essa estrutura institucional estabelecida, foi promulgada, em 28 de novembro de 2000, a Lei $\mathrm{n}^{\circ} 10.052$, que instituiu 0 Fundo para Desenvolvimento Tecnológico das Telecomunicações - Funttel, de acordo com a previsão do art. 77 da LGT.

$\mathrm{Na}$ proposta inicial do Ministério das Comunicações, o Fundo se chamaria FDTT - Fundo para o Desenvolvimento Tecnológico das Telecomunicações, seria gerido pela Anatel e o agente financeiro seria 0 BNDES. No entanto, após passar por emendas no Congresso Nacional, o fundo acabou se chamando Funttel, sendo gerido pelo próprio Ministério das Comunicações e tendo como agentes financeiros o BNDES e a FINEP.

Segundo a própria lei, o objetivo do fundo era "estimular o processo de inovação tecnológica, incentivar a capacitação de recursos humanos, fomentar 
a geração de empregos e promover o acesso de pequenas e médias empresas a recursos de capital, de modo a ampliar a competitividade da indústria brasileira de telecomunicações, nos termos do art. 77 da Lei no 9.472".

Para conseguir esses objetivos, as receitas do fundo seriam provenientes das seguintes fontes, conforme art. $4^{\circ}$ da Lei $n^{\circ} 10.052$ :

- Dotações consignadas na lei orçamentária anual e seus créditos adicionais;

- Meio por cento da receita bruta das prestadoras de serviço de telecomunicações, descontados alguns impostos;

- $\quad U m$ por cento da receita de eventos participativos realizados por meio de ligações telefônicas;

- Rendimento das aplicações do fundo;

- Doações;

- 100 milhões iniciais provenientes do Fistel.

Além desses, existia um item vetado, o qual correspondia a parcela anual do Fistel (outro fundo que tem como objetivo principal suportar as atividades da Anatel), que segundo, a mensagem de veto, foi retirado por sugestão do Ministério da Fazenda, por desviar recursos de um fundo específico para outros fins e o entrelaçamento entre fundos comprometia a transparência e a o interesse público.

Do ponto de vista de gestão, o Funttel seria administrado por um Conselho Gestor, composto por representantes das seguintes entidades:

- Ministério das Comunicações;

- $\quad$ Ministério da Ciência e Tecnologia;

- Ministério do Desenvolvimento, Indústria e Comércio Exterior;

- $\quad$ Agência Nacional de Telecomunicações - Anatel;

- Banco Nacional de Desenvolvimento Econômico e Social BNDES;

- $\quad$ Empresa Financiadora de Estudos e Projetos - FINEP.

Observa-se que, apesar das atividades de desenvolvimento tecnológico já não mais estarem vinculadas ao Estado, toda a gestão do fundo que suportaria as atividades é gerido somente por entidades estatais. Outro setor 
que também não está representado é a academia, um importante elo na cadeia de desenvolvimento tecnológico.

Após o estabelecimento do fundo, a sua arrecadação e execução ocorreram segundo os valores da tabela abaixo:

Tabela 3 - Arrecadação e realização dos recursos do Funttel.

\begin{tabular}{|c|c|c|c|}
\hline Período & $\begin{array}{c}\text { Receitas de } \\
\text { Arrecadação (R\$) }\end{array}$ & $\begin{array}{c}\text { Realizado não } \\
\text { reembolsável (R\$) }\end{array}$ & Realizado (R\$) \\
\hline 2001 & $127.186 .525,30$ & $57.810 .000,00$ & $57.810 .000,00$ \\
\hline 2002 & $202.925 .981,35$ & $92.271 .471,80$ & $92.271 .471,80$ \\
\hline 2003 & $214.472 .340,86$ & $153.717 .478,00$ & $153.717 .478,00$ \\
\hline 2004 & $242.364 .744,52$ & $100.696 .815,20$ & $105.155 .916,00$ \\
\hline 2005 & $272.161 .247,85$ & $102.021 .839,00$ & $105.352 .481,00$ \\
\hline 2006 & $305.909 .024,55$ & $78.033 .810,10$ & $92.451 .384,00$ \\
\hline 2007 & $331.652 .031,50$ & $137.476 .326,52$ & $150.647 .692,52$ \\
\hline 2008 & $377.621 .451,53$ & 70.613.359,93 & $90.613 .359,93$ \\
\hline 2009 & $392.046 .712,03$ & $40.154 .272,87$ & $40.154 .272,87$ \\
\hline 2010 & $421.082 .386,83$ & $50.704 .224,61$ & $100.704 .224,61$ \\
\hline 2011 & 493.895.749,91 & $71.875 .088,82$ & $121.875 .088,82$ \\
\hline 2012 & $547.957 .735,77$ & $\begin{array}{c}\text { Não disponível / Não } \\
\text { encontrado }\end{array}$ & $\begin{array}{c}\text { Não disponível / Não } \\
\text { encontrado }\end{array}$ \\
\hline 2013 & $547.873 .464,35$ & $\begin{array}{c}\text { Não disponível / Não } \\
\text { encontrado }\end{array}$ & $\begin{array}{c}\text { Não disponível / Não } \\
\text { encontrado }\end{array}$ \\
\hline TOTAIS & 4.477.149.396,35 & $955.374 .686,85$ & $1.110 .753 .369,55$ \\
\hline
\end{tabular}

Fonte: Ministério das Comunicações ${ }^{15}$.

Como se pode perceber da tabela acima, os valores arrecadados nos treze anos considerados foram superiores a quatro bilhões de reais, o que é um valor expressivo e poderia significar uma importante linha de financiamento do desenvolvimento tecnológico nacional. No entanto, observa-se que a

15 Valores não corrigidos. Disponível em http://www.mc.gov.br/acoes-e-programas/inovacaotecnologica/fundo-para-o-desenvolvimento-tecnologico-das-telecomunicacoes-funttel/392temas/inovacao-tecnologica/fundo-para-o-desenvolvimento-tecnologico-das-telecomunicacoesfunttel/23762-receita-e-orcamento 
tendência de aumento da arrecadação não foi acompanhada por um aumento na execução, que tem até diminuído, especialmente após 2007. Esse fato é preocupante, pois pode indicar uma baixa priorização do tema e que o fundo tem perdido a sua importância, seja pela dificuldade de acessar esses recursos ou mesmo pelo desinteresse no empreendimento de negócios de natureza tecnológica no Brasil.

\subsubsection{A criação de um Sistema Setorial de Inovação}

A partir da criação do Funttel, foi criado um Sistema Setorial de Inovação em Telecomunicações, conforme terminologia utilizada por Shima (2007). Esta visão é legada do período anterior, em que o desenvolvimento de telecomunicações era mais insulado, do ponto de vista da necessidade de interação com outros setores, uma vez que, sendo um setor de monopólio estatal, o Estado era o agente preponderante na orientação dos caminhos a serem seguidos.

A partir da privatização, do surgimento da comutação por pacotes, da expansão da Internet, das comunicações móveis e do aumento da importância do setor para a economia, surge a necessidade de se compreender melhor a relação entre os diversos agentes para que uma política tenha os efeitos almejados pelo Estado e pela sociedade.

A percepção de que o Estado é o principal agente orientador das políticas de desenvolvimento tecnológico é claramente percebido ao se observar a composição do Conselho Gestor do Funttel, que, conforme descrito anteriormente, é composto somente por representantes de entidades governamentais.

Este fato relega a existência de um ecossistema do setor de TICs, envolvendo outros agentes setoriais e a dinâmica da geração de inovação. Para que se compreenda uma pouco melhor essa afirmação, passa-se a descrever o setor de TICs e posteriormente o ecossistema que compõe esse setor.

\subsubsection{Descrição dos agentes, conforme a política vigente}

Os agentes que fazem parte do SSI (Sistema Setorial de Inovação) são assim esquematizados por Sousa (2011): 


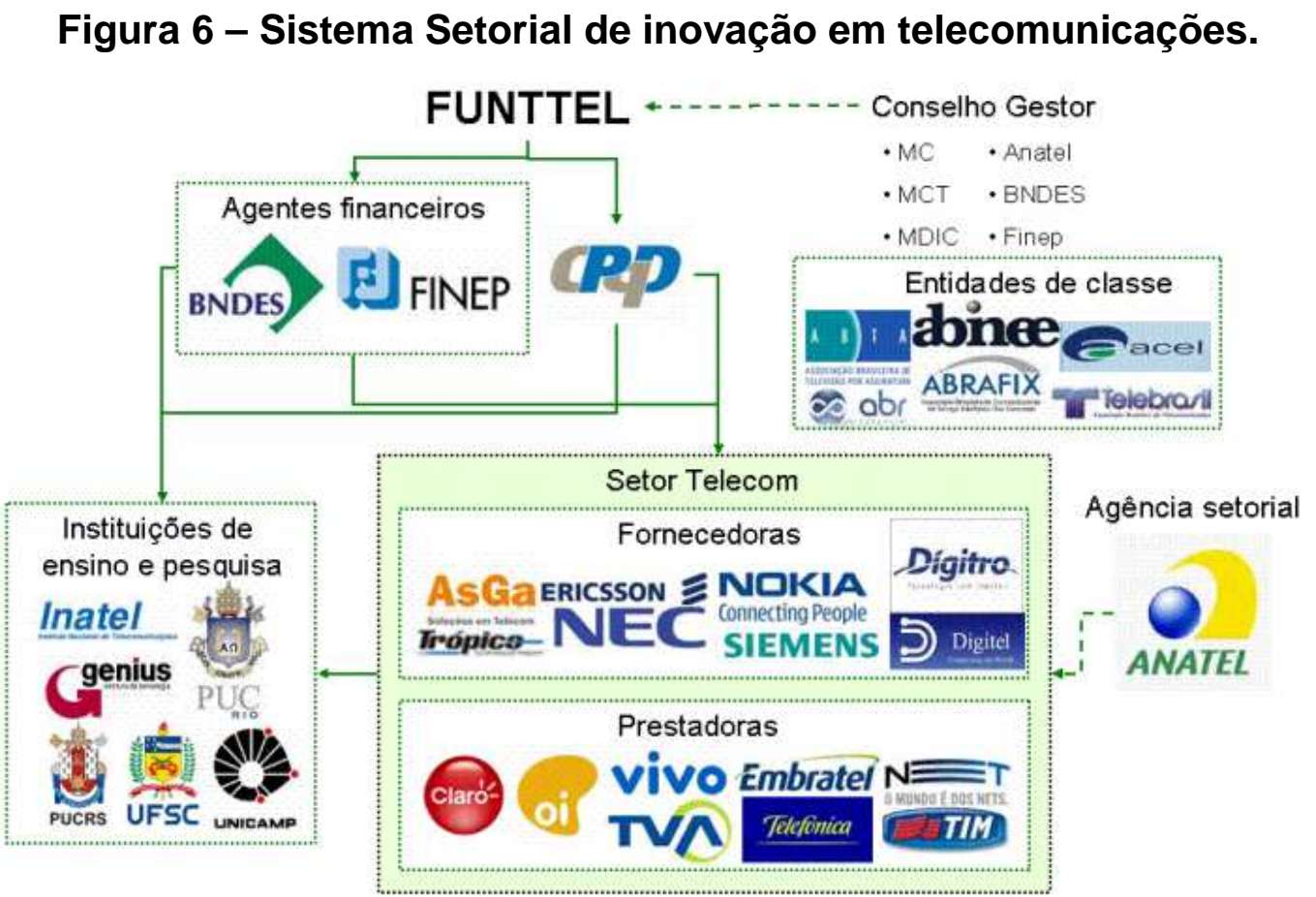

Fonte: Sousa (2011).

Essa figura descreve basicamente como o SSI tem funcionado desde 1997. Como se pode perceber, os "clientes" desse modelo são basicamente três:

- Instituições de ensino e pesquisa;

- $\quad$ Empresas fornecedoras de equipamentos;

- $\quad$ Empresas prestadoras de serviços.

Esses agentes são "alimentados" por agentes financeiros (FINEP e BNDES), que disponibilizam capital vindo do Funttel. A Anatel tem apenas um papel secundário no desenvolvimento tecnológico, por regular e estabelecer padrões para a ação das empresas de prestadoras de serviços de telecomunicações e por certificar os produtos utilizados nas redes, criando, de certa forma, uma barreira de entrada para equipamentos estrangeiros (apesar das dificuldades em se coordenar ações para impedir a entrada de equipamentos irregulares).

Percebe-se que o modelo traçado é altamente linear e unidirecional. As instituições de ensino e pesquisa têm atividades acadêmicas sem um foco concreto no mercado. Os resultados das pesquisas são utilizados pelos fornecedores no desenvolvimento de equipamentos. Esses equipamentos e soluções são entregues às prestadoras, que, por sua vez, servem os 
consumidores. Nesse contexto, percebe-se a função das instituições de ensino e pesquisa no desenvolvimento de ciência básica, a qual pode ser aproveitada posteriormente pelas empresas.

No entanto, há ainda um segundo importante papel desenvolvido pela academia, o de formar mão de obra especializada. Entende-se aqui não somente mão de obra técnica nos diversos ramos da engenharia elétrica (eletrônica, telecomunicações, computação), mas também profissionais especializados em negócios, que saibam empreender, inovar e desenvolver tecnologias/produtos/serviços que possam melhorar a vida das pessoas.

Além disso, percebe-se que não existem muitos feedbacks das entidades privadas, a não ser as prestações de contas ao Funttel. Entretanto, tais entidades não participam do processo de orientação da política.

\subsubsection{Algumas considerações iniciais sobre o modelo de SSI vigente}

Percebe-se que esse modelo de SSI descrevia bem o funcionamento do setor antes da privatização das prestadoras e antes do surgimento e popularização da internet. Contudo, esses fatos deixam o ambiente menos linear por diminuir as barreiras para o surgimento de inovações. Essa não linearidade exige um novo modelo de colaboração entre os diferentes agentes.

Nesse novo cenário, os mercados tornaram-se globais. Tanto 0 fornecimento de serviços, quanto o fornecimento de equipamentos e soluções começam a ser compostos, em grande medida, por grupos internacionais. Esses grupos investem na compra de prestadores de serviços, desenvolvedores de soluções, dentre outras empresas, organizando-se em alianças globais de padronização e desenvolvimento tecnológico.

Com essas alterações, alguns agentes que atualmente podem ter significativa importância podem não ter sido contemplados na estrutura institucional estabelecida pela legislação brasileira.

Primeiramente, citamos entidades de padronização internacionais. Por excelência, a UIT (União Internacional de Telecomunicações) tem esse papel. No entanto, sendo a UIT uma entidade intergovernamental, ela perdeu parte de sua expressividade nos últimos anos, uma vez que grande parte dos Estados membros privatizou seu sistema de telecomunicações, exercendo suas políticas públicas por meio de regulação e não diretamente realizando 
desenvolvimentos ou prestando serviços de telecomunicações. Desta forma, abriu-se espaço para conglomerados e associações privadas, cada vez mais internacionalizadas, num contexto de crescente globalização, ocorrida em parte também pelo desenvolvimento de melhores e mais baratas formas de comunicação.

Cabe destacar que até o papel da UIT foi alterado ao longo do tempo. Inicialmente, a UIT foi criada para garantir interoperabilidade de sistemas (sistemas de comunicações de aviões e embarcações, por exemplo, que eram fabricados localmente) e facilitar as comunicações. Ao longo do tempo, a UIT passou a ser arena de influências para que alguns padrões pudessem se sobrepor em escala mundial ou regional ${ }^{16}$ a outros na disputa de mercados.

Houve, assim, uma mudança no eixo de desenvolvimento. Antes, o arranjo institucional estava focado em centros de desenvolvimento ligados diretamente às operadoras (Bell Labs é o maior dos exemplos), muitas vezes estatais. Agora, os fóruns padronizadores começaram a ser alianças empresariais, na maioria das vezes transnacionais, como o 3GPP, o UMTS fórum, IEEE, WiMax Fórum, dentre outros. Isso se deve à alteração no papel dos Estados, que passou a ser secundário, relacionado à regulação, criação de linhas de crédito e, em alguns casos, formação de mão de obra qualificada.

Esse novo (até então) cenário propiciou o surgimento de diversos novos agentes, com grande potencial de crescimento, o que causou a chamada "bolha do ponto com" no final dos anos 1990 e início dos anos 2000. Essas empresas já não eram mais de telecomunicações, mas sim de um setor maior, conhecido como TICs (Tecnologias de Informação e Comunicação), mais bem descrito abaixo.

O modelo vigente, apesar de o Estado não estar presente em nenhuma parte da entrega de produtos ou serviços à população, sua posição ainda é crucial, pois ele permanece como o tomador de decisões relacionadas ao desenvolvimento tecnológico. Isso pode ser observado, por exemplo, quando se nota que todos os membros do conselho gestor do Funttel são entidades estatais.

\footnotetext{
${ }^{16}$ As regiões consideradas pela UIT são três (Região 1 - Europa, África e Oriente Médio, Região 2 Américas, Região 3 - Ásia e Pacífico), refletindo regiões de influência de países líderes tecnológicos.
} 
Esse arranjo, como dito anteriormente, não contempla e distancia outros agentes do processo, como as prestadoras de serviço, que não se engajam na utilização dos recursos para inovação que tragam benefícios para elas mesmas e encaram a contribuição para o Funttel apenas como um tributo. Um possível novo arranjo deveria buscar o engajamento das prestadoras e de outros agentes na utilização desses recursos para geração de inovações de telecomunicações demandas pelas diferentes realidades brasileiras.

\subsection{SOBRE A UIT}

\subsubsection{Estrutura da UIT}

A UIT é dividida basicamente em 3 setores:

- Radiocomunicações;

- Padronização; e

- Desenvolvimento.

Para os objetivos deste capítulo, será aprofundada a estrutura do Setor de Radiocomunicações, o UIT-R, que é o setor responsável por questões relacionadas ao espectro de radiofrequências e órbita de satélites.

Importante mencionar que a UIT não é apenas um fórum de discussão para questões internacionais, mas tem também algumas funções operacionais, como ser o repositório de notificações de estações terrestres, terrenas (estações em terra de comunicação satelital) e satelitais. Essas informações permitem a coordenação em zonas de fronteira, bem como de serviços de radiocomunicações que têm escala transnacional.

Grande parte do trabalho da UIT-R é realizado em grupos de estudo (Study Groups), que podem ser reorganizados a cada Assembleia de Radiocomunicações (Radiocommunications Assembly), que ocorrem em períodos de cerca de 2 a 3 anos. A estrutura aprovada pela WRC-12 e que vigora para o período estudado é assim descrita: 
Figura 7 - Estrutura da UIT-R.

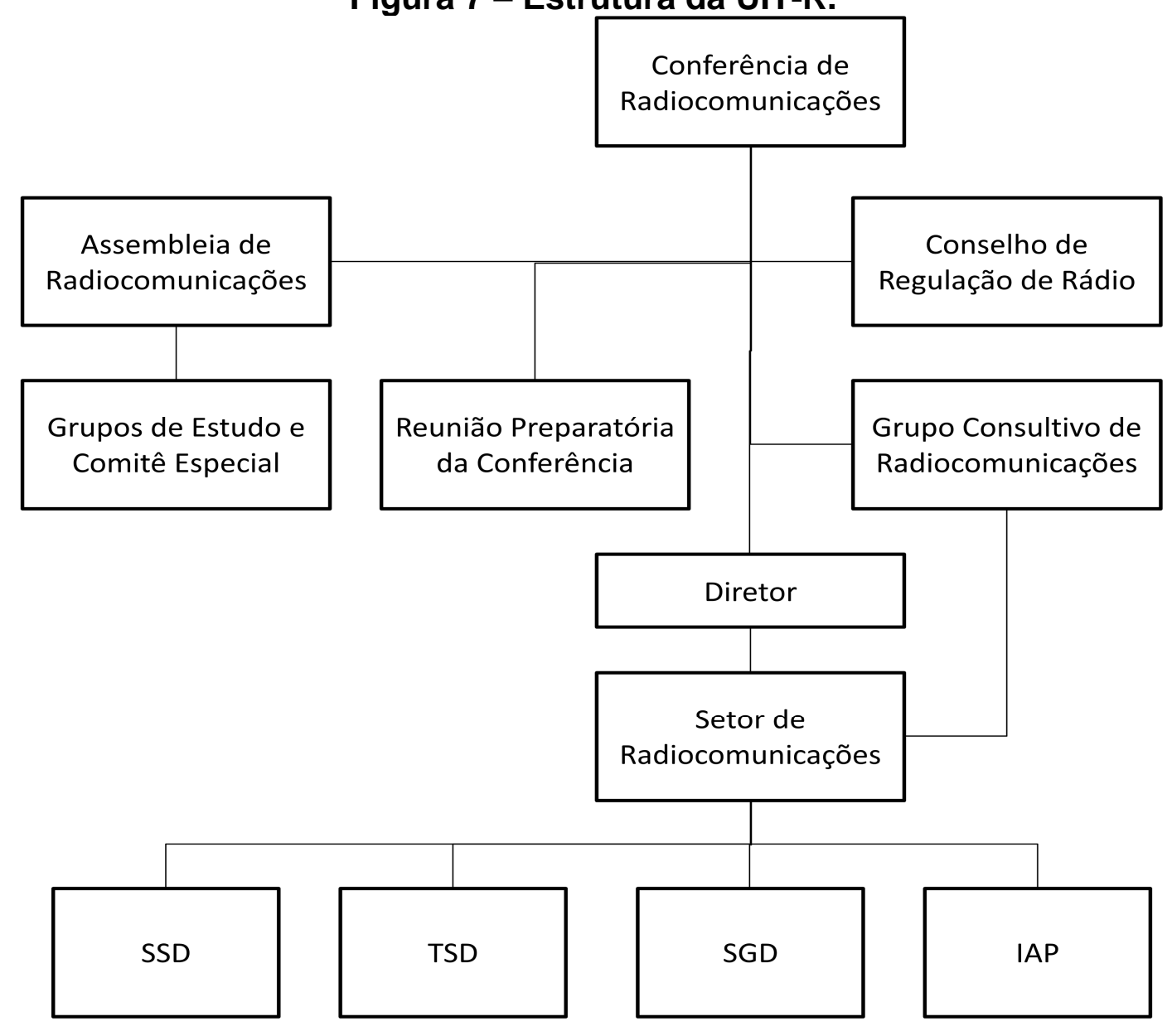

Fonte: UIT.

Sendo que as siglas significam o seguinte:

- $\quad$ SSD - Departamento de Serviços Espaciais;

- TSD - Departamento de Serviços Terrestres;

- $\quad$ SGD - Departamento de Grupos de Estudo;

- $\quad$ IAP - Departamento de Informática, Administração e Publicações.

O SSD é responsável pela coordenação e procedimentos de registro dos sistemas satelitais e das estações terrenas. O departamento lida com a captura, o processamento e a publicação de dados de estações. Além disso, conduz avaliações das notificações de frequências submetidas pelas administrações para inclusão no processo formal de coordenação no Registro Internacional Mestre de Frequência (MIFR - Master International Frequency Register). O departamento ainda é responsável por gerenciar os procedimentos para planos de atribuição de frequências na UIT e a assistência às administrações para todos esses assuntos. 
O TSD conduz funções técnicas e regulatórias. Ademais, ele provê assistência às administrações sobre gerenciamento internacional de espectro, de acordo com o especificado no Radio Regulations e em vários acordos regionais relativos a serviços terrestres (radiodifusão, fixo, móvel marítimo, móvel aeronáutico, etc). Ele ainda processa as notificações de atribuição de frequência e mantém o Registro e Plano Mestre relativo a frequências de serviços terrestres.

O SGD, por meio de seus diversos grupos de estudo, desenvolve as bases técnicas para as decisões tomadas nas Conferências, além de desenvolver padrões globais (Recomendações), Relatórios e Manuais. Na atual estrutura, os Grupos de Estudo estão assim constituídos:

- $\quad$ Grupos de Estudo 1 (SG 1) - Gerenciamento de espectro;

- $\quad$ Grupos de Estudo 3 (SG 3) - Propagação de radiofrequência;

- $\quad$ Grupos de Estudo 4 (SG 4) - Serviços satelitais;

- $\quad$ Grupos de Estudo 5 (SG 5) - Serviços terrestres;

- $\quad$ Grupos de Estudo 6 (SG 6) - Serviços de radiodifusão;

- $\quad$ Grupos de Estudo 7 (SG 7) - Serviços Científicos.

Além deles, há também grupos com tarefas específicas, como os seguintes:

- $\quad$ Comitê de Coordenação de Vocabulário (CCV);

- Reunião Preparatória para Conferência (CPM);

- Comitê Especial para assuntos regulatórios e procedimentais (SC);

- Grupo de Tarefa Conjunta (JTG 4-5-6-7) - WRC-15 Itens de Agenda 1.1 and 1.2 .

Desta forma, grande parte da estrutura permanente da UIT-R está alocado em tarefas de registro de frequências e construção de bases de dados que servirão para a coordenação internacional. Do ponto de vista regulatório, esses registros são referências para os procedimentos de coordenação e características técnicas dos sistemas, que são definidos pelas diversas publicações da UIT-R, desde o Radio Regulations, até os Relatórios, passando também por Recomendações, tema que será mais bem tratado na próxima sessão. 
Vale mencionar novamente que o papel da UIT tem diminuído ante outras organizações internacionais de padronização privadas, como o IEEE, o 3GPP, a GSMA e a ICANN. Isso porque com a privatização de grande parte das redes de telecomunicações, o papel dos Estados nas telecomunicações e, consequentemente da UIT, tem se reduzido. Entretanto, em algumas áreas, como a de radiocomunicações, a importância da UIT permanece, uma vez que os Estados não delegaram à iniciativa privada a competência de estabelecer regulamentações sobre espectro.

\subsubsection{Publicações}

Os documentos que compõem a estrutura legal da UIT e têm status de tratado, com efeito vinculante sobre os membros, são a Constituição e a Convenção da UIT, bem como as regulações administrativas, que complementam a Constituição e a Convenção.

Um desses instrumentos administrativos é o Regulamento de Radiocomunicações (Radio Regulations - RR). A edição do RR considerada para este estudo é de 2012, aprovada após a Conferência Mundial de Radiocomunicações (WRC-12). Esse documento lista as maneiras de coordenação internacional de frequência, incluindo em zonas de fronteira, lista as tabelas de atribuição de radiofrequências, suas restrições e uma série de apêndices técnicos relativos à coordenação de satélites e de radiofrequências. O RR é o único documento com status de tratado para o setor de radiocomunicações, mas outros documentos também são produzidos, como Recomendações e Relatórios.

Um documento complementar ao RR são as "Regras de Procedimento" (Rules of Procedure). Esse documento é publicado pelo RRB (Radio Regulations Board) com esclarecimentos sobre a aplicação do RR ou estabelecendo procedimentos práticos que podem não estar previstas nas provisões regulatórias existentes.

As Recomendações, por sua vez, são um conjunto de padrões que não têm sua implementação mandatória pelos Estados membros. No entanto, tais Recomendações têm um grande respeito pela sua forma multilateral e multissetorial de desenvolvimento. As Recomendações são organizadas em séries, que se referem a cada um dos serviços abordados: 
Tabela 4 - Séries de Recomendações da UIT-R.

\begin{tabular}{|l|l|}
\hline Série & Área de Estudo \\
\hline BO & Distribuição por satélite \\
\hline BR & Gravação para produção, arquivamento, reprodução e filmes para TV \\
\hline BS & Serviço de Radiodifusão (áudio) \\
\hline BT & Serviço de Radiodifusão (televisão) \\
\hline F & Serviço Fixo \\
\hline M & Serviço Móvel \\
\hline P & Propagação de ondas de rádio \\
\hline RA & Radioastronomia \\
\hline RS & Sistemas de sensoriamento remoto \\
\hline S & Serviço Fixo por Satélite \\
\hline SA & Aplicações espaciais e meteorologia \\
\hline SF & $\begin{array}{l}\text { Compartilhamento de frequência e coordenação entre sistemas de } \\
\text { serviço fixo e serviço fixo por satélite }\end{array}$ \\
\hline SM & Gerenciamento de espectro \\
\hline SNG & Coleta de informações por satélite \\
\hline TF & Sinais temporais e padrões de emissões de frequência \\
\hline V & Vocabulário e sistemas relacionados \\
\hline
\end{tabular}

Os Relatórios (Reports) não têm o caráter de padrões, mas expressam a visão da comunidade sobre algum tema estudado. Esses relatórios são preparados em resposta a alguma questão demandada aos Grupos Estudo pela Conferência. Eles (Relatórios) indicam tendências, apontam necessidades comuns, experiências bem sucedidas, assim como servem de base para as Recomendações e alterações no RR. Eles são, portanto, referências sobre as decisões da UIT, bem como servem de paradigma para atuação dos Estados membros.

Os Manuais (Handbooks) são também importantes documentos, pois servem de orientação para diversos países, especialmente os em desenvolvimento, para tópicos em que a experiência de outros países pode servir de exemplo. É um documento que induz seguidores tecnológicos a implementarem tecnologias da maneira sugerida pelos desenvolvedores, em especial porque é geralmente construído com baixa participação dos países que serão usuários desses manuais.

Há que se mencionar também que as Opiniões da UIT-R (ITU- $R$ Opinions) são declarações com caráter administrativo, para colaboração com outros setores da UIT, outras agências especializadas da ONU ou outros 
agentes, incluindo Estados membros. Esses documentos, muitas vezes expressam o que a UIT-R considera importante, servindo com influência para a construção de agendas pelos Estados membros.

\subsubsection{Divisão em Regiões}

Importante mencionar que o RR divide o mundo em 3 regiões, conforme a figura abaixo:

\section{Figura 8 - Divisão em regiões adotada pela UIT.}

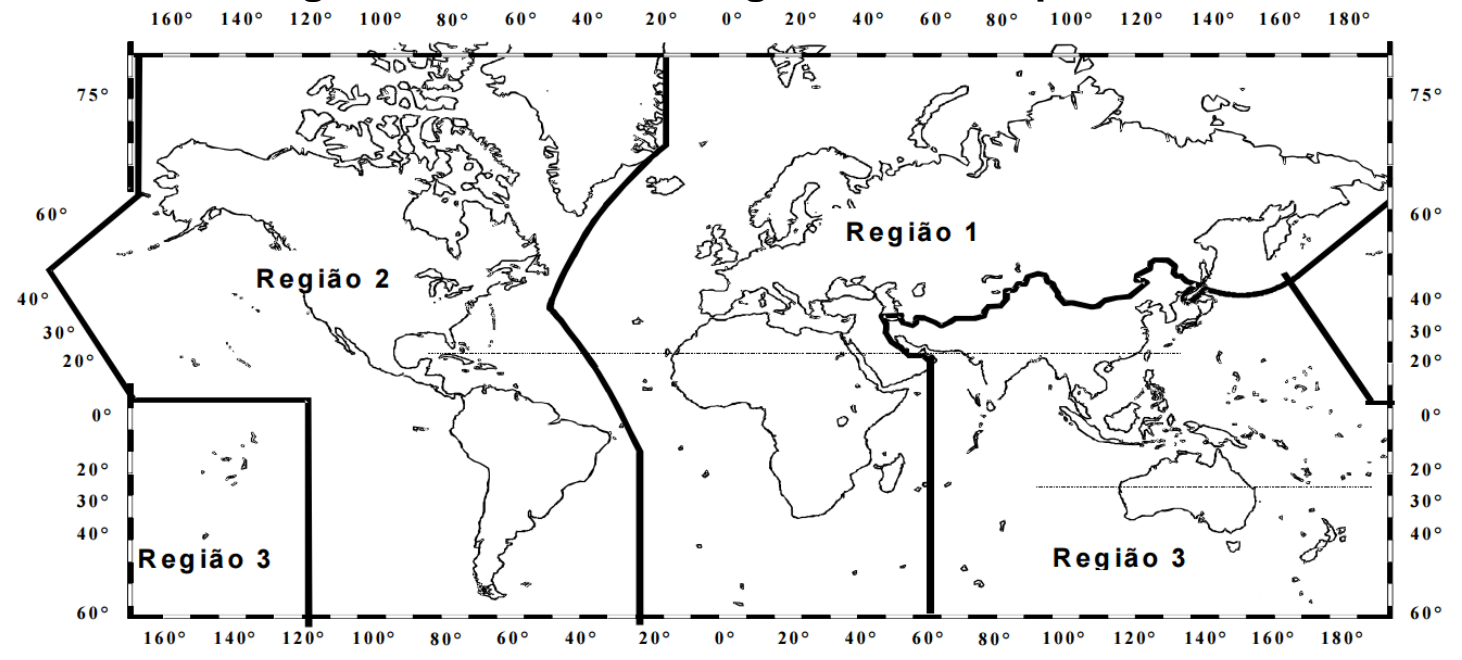

Fonte: UIT.

De maneira geral, as regiões são descritas da seguinte forma:

- Região 1 - Europa, África e Oriente Médio;

- Região 2 - Américas;

- Região 3 - Ásia e Pacífico.

Essa divisão é importante porque as regulamentações geralmente são específicas para cada uma das regiões. Assim, cada região tem alocações específicas, apesar de, em muitos casos, haver uma harmonização global. Outra externalidade dessa divisão regional, é que ela reflete zonas de influência tecnológica, em que cada região tem expoentes tecnológicos que conseguem mais facilmente assegurar seus interesses em sua região de influência.

Apesar dessa necessidade de harmonização intrarregional, as especificidades de cada países podem também ser listadas em notas de rodapé. Apenas a título exemplificativo de como funciona tal mecanismo, 
abaixo está um trecho dessa tabela de alocações de frequências, presente do art. $5^{\circ}$ do $\mathrm{RR}$, em que há uma exceção específica para o Brasil $^{17}$ :

Tabela 5 - Trecho exemplificativo da tabela de alocações do RR.

\begin{tabular}{|c|c|c|}
\hline \multicolumn{3}{|c|}{ Alocação de serviços } \\
\hline Região 1 & Região 2 & Região 3 \\
\hline $460-470$ & \multicolumn{2}{|c|}{$\begin{array}{l}\text { FIXO } \\
\text { MÓVEL 5.286AA } \\
\text { Meteorologia-satélite (espaço-Terra) } \\
5.287 \quad 5.288 \quad 5.2895 .290\end{array}$} \\
\hline \multirow[t]{6}{*}{$\begin{array}{l}470-790 \\
\text { RADIODIFUSÃO }\end{array}$} & \multirow{3}{*}{\begin{tabular}{|l|}
$\mathbf{4 7 0}-512$ \\
RADIODIFUSÃO \\
Fixo \\
Móvel \\
5.2925 .293 \\
$\mathbf{5 1 2 - 6 0 8}$ \\
RADIODIFUSÃO \\
5.297
\end{tabular}} & \multirow[t]{2}{*}{$\begin{array}{l}470-585 \\
\text { FIXO } \\
\text { MÓVEL } \\
\text { RADIODIFUSÃO } \\
5.2915 .298\end{array}$} \\
\hline & & \\
\hline & & \multirow{2}{*}{$\begin{array}{l}585-610 \\
\text { FIXO } \\
\text { MÓVEL } \\
\text { RADIODIFUSÃO } \\
\text { RADIONAVEGAÇÃO } \\
5.1495 .3055 .3065 .307\end{array}$} \\
\hline & \multirow[t]{2}{*}{$\begin{array}{l}\text { 608-614 } \\
\text { RADIOASTRONOMIA } \\
\text { Móvel- exceto satélite } \\
\text { móvel aeronáutico por satélite } \\
\text { (Terra-espaço) }\end{array}$} & \\
\hline & & \multirow{6}{*}{$\begin{array}{l}610-890 \\
\text { FIXO } \\
\text { MÓVEL 5.313A 5.317A } \\
\text { RADIODIFUSÃO }\end{array}$} \\
\hline & $\begin{array}{l}\text { 614-698 } \\
\text { RADIODIFUSÃO } \\
\text { Fixo } \\
\text { Móvel } \\
5.2935 .3095 .311 \mathrm{~A}\end{array}$ & \\
\hline $\begin{array}{l}5.3005 .3045 .3065 .311 A \\
5.3125 .312 A\end{array}$ & $\begin{array}{l}\text { 698-806 } \\
\text { MÓVEL 5.313B 5.317A } \\
\text { RADIODIFUSÃO } \\
\text { Fixo }\end{array}$ & \\
\hline $790-862$ & $5.2935 .3095 .311 \mathrm{~A}$ & \\
\hline $\begin{array}{l}\text { MÓVEL exceto aeronáutico } \\
\text { móvel 5.316B 5.317A } \\
\text { RADIODIFUSÃO } \\
5.3125 .3145 .3155 .316 \\
5.316 A 5.319\end{array}$ & \multirow[t]{3}{*}{$\begin{array}{l}806-890 \\
\text { FIXO } \\
\text { MÓVEL 5.317A } \\
\text { RADIODIFUSÃO }\end{array}$} & \\
\hline $\begin{array}{l}862-890 \\
\text { FIXO } \\
\text { MÓVEL exceto aeronáutico } \\
\text { móvel 5.317A } \\
\text { RADIODIFUSÃO } 5.322\end{array}$ & & \\
\hline 5.3195 .323 & & $\begin{array}{l}5.1495 .3055 .3065 .307 \\
5.311 A 5.320\end{array}$ \\
\hline
\end{tabular}

5.313B Categoria de serviço distinta: no Brasil, a alocação da faixa de 698-806 MHz para o serviço móvel é em caráter secundário (veja ${ }^{\circ} 5.32$ ). (CMR-07) ${ }^{18}$

Fonte: UIT

\footnotetext{
${ }^{17}$ Vale mencionar que nem todas as notas de rodapé são exceções de algum país, mas podem ser detalhamentos de alguma regulamentação para aquela faixa de radiofrequências.

${ }^{18}$ Tradução livre.
} 
Quanto à participação das nações nos serviços administrativos da UIT, tem-se a seguinte distribuição, apresentada pelo Relatório de Recursos Humanos da UIT de $2015^{19}$ :

Tabela 6 - Funcionários em categorias superiores da UIT de acordo com sua nacionalidade.

\begin{tabular}{|l|r|r|r|r|r|r|r|r|}
\hline Nacionalidade & $\mathbf{2 0 0 8}$ & $\mathbf{2 0 0 9}$ & $\mathbf{2 0 1 0}$ & $\mathbf{2 0 1 1}$ & $\mathbf{2 0 1 2}$ & $\mathbf{2 0 1 3}$ & $\mathbf{2 0 1 4}$ & $\mathbf{2 0 1 5}$ \\
\hline Francês & $\mathbf{4 8}$ & 53 & 52 & 48 & 53 & 50 & 54 & 54 \\
\hline Britânico & 21 & 21 & 21 & 20 & 20 & 19 & 19 & 19 \\
\hline Canadense & 11 & 12 & 12 & 13 & 18 & 17 & 17 & 18 \\
\hline Italiano & 9 & 8 & 12 & 13 & 15 & 17 & 17 & 17 \\
\hline Espanhol & 12 & 13 & 12 & 13 & 15 & 16 & 16 & 15 \\
\hline Russo & 12 & 13 & 13 & 12 & 15 & 13 & 13 & 13 \\
\hline Chinês & 8 & 8 & 9 & 10 & 11 & 12 & 12 & 12 \\
\hline Indiano & 13 & 13 & 12 & 12 & 13 & 11 & 11 & 11 \\
\hline Filipino & 7 & 7 & 8 & 10 & 11 & 10 & 10 & 10 \\
\hline Americano & 16 & 14 & 15 & 15 & 14 & 8 & 8 & 8 \\
\hline Total & $\mathbf{3 1 5}$ & $\mathbf{3 3 3}$ & $\mathbf{3 4 0}$ & $\mathbf{3 5 1}$ & $\mathbf{3 6 9}$ & $\mathbf{3 7 7}$ & $\mathbf{3 9 1}$ & $\mathbf{3 9 0}$ \\
\hline
\end{tabular}

Como se pode perceber, há uma de funcionários oriundos da Região 1, especialmente da Europa. Isso se deve, em grande parte, à localização da sede da UIT em Genebra, muito próxima da França. Apesar disso, percebe-se também a presença de líderes tecnológicos de cada Região (França: Região 1; EUA: Região 2; China: Região 3), com as notáveis ausências de Japão e Alemanha. Não se pode negligenciar também a presença de nações que historicamente exercem influência em função das seis línguas oficiais da UIT (inglês, francês, espanhol, chinês, árabe e russo), com Espanha e Rússia. Segundo o relatório, há também critérios de distribuição geográfica, de modo que dos 193 Estados membros, 101 estavam representados e o Brasil contava com 9 representantes.

\subsubsection{Agentes participantes da UIT}

A UIT é um fórum de Estados. Essa estrutura reflete a maneira tradicional de se ver telecomunicações e de prestação de serviços ao redor do mundo. Como já mencionado, a UIT foi criada há 150 anos e durante muito tempo a prestação de serviços de telecomunicações em grande parte dos países foi feita por monopólios estatais. Isso justifica a criação de uma estrutura de governança em que a representação é feita por Estados membros.

\footnotetext{
${ }^{19}$ Disponível em: https://www.itu.int/md/dologin_md.asp?lang=en\&id=S15-CL-INF-0008!!PDF-E
} 
Entretanto, nas últimas décadas, os Estados já não mais têm monopólios e o desenvolvimento tecnológico passou quase que totalmente para a iniciativa privada. Esse novo cenário criou pressões para a maior participação de agentes privados nas decisões da UIT. Essa necessidade gerou até uma alteração na Constituição da UIT, com a inserção, na Conferência de Plenipotenciários de 1998, de um novo objetivo da instituição ("a bis"):

“1 Os propósitos da União são:

a) manter e estender a cooperação internacional entre todos os seus Estados membros, para melhoria e o uso racional de todos os tipos de telecomunicações;

a bis) promover e aprimorar a participação de entidades $e$ organizações nas atividades da União e promover a cooperação frutífera e a parceira entre Estados membros para o cumprimento dos objetivos gerais consagrados nos propósitos da União;"20

Esse incentivo se reflete na participação, pois a UIT conta com mais de 564 membros setoriais, 169 associados e 109 representantes da Academia ${ }^{21}$. Apenas a título ilustrativo, as instituições brasileiras registradas são as seguintes:

Membros setorias:

Tabela 7 - Membros setoriais brasileiros na UIT.

\begin{tabular}{|l|c|c|c|}
\hline Nome & UIT-R & UIT-T & UIT-D \\
\hline $\begin{array}{l}\text { Empresa Brasileira de Telecomunicações S.A. } \\
\text { (EMBRATEL), RIO DE JANEIRO, RJ } 22\end{array}$ & $\mathbf{X}$ & & \\
\hline $\begin{array}{l}\text { Fundação Instituto Nacional de Telecomunicações - } \\
\text { FINATEL, SANTA RITA DO SAPUCAÍ }\end{array}$ & & & $\mathbf{X}$ \\
\hline $\begin{array}{l}\text { Fundacao CPqD - Centro de Pesquisa e } \\
\text { Desenvolvimento em Telecomunicacoes, CAMPINAS }\end{array}$ & Univ & Univ & Univ \\
\hline Universidade Federal do Para, BELEM, PA & Univ & Univ & Univ \\
\hline
\end{tabular}

Fonte: UIT.

\footnotetext{
${ }^{20}$ Tradução livre.

${ }^{21}$ http://www.itu.int/en/membership/Pages/sector-members.aspx

${ }^{22}$ A Embratel é reconhecida pela UIT um membro de antigo, com participação desde 1971. Entretanto, há membros com mais de 75 anos, sendo o mais antigo a Cable \& Wireless Communications Plc, do Reino Unido, que é membro desde 1871.
} 
Associados:

Tabela 8 - Associados brasileiros na UIT.

\begin{tabular}{|ll|l|l|c|}
\hline Nome & ITU-R & ITU-T & ITU-D \\
\hline $\begin{array}{l}\text { ADVISIA OC\&C Strategy Consultants, SAO } \\
\text { PAULO }\end{array}$ & & & $\begin{array}{c}\text { Associado } \\
\text { SG1 }\end{array}$ \\
\hline
\end{tabular}

Fonte: UIT.

Academia:

Tabela 9 - Membros brasileiros da academia na UIT.

\begin{tabular}{|l|c|c|c|}
\hline Nome & ITU-R & ITU-T & ITU-D \\
\hline $\begin{array}{l}\text { Fundacao CPqD - Centro de Pesquisa e } \\
\text { Desenvolvimento em Telecomunicacoes, CAMPINAS }\end{array}$ & Univ & Univ \\
\hline Universidade Federal do Para, BELEM, PA & Univ & Univ & Univ \\
\hline
\end{tabular}

Fonte: UIT.

Apesar de os membros da iniciativa privada terem sua participação incentivada, eles não têm poder de voto em eleições. Isso é bastante importante em questões eleitorais para decisão dos altos escalões dos organismos, mas tem pouca influência para a aprovação das publicações.

Isso porque a aprovação da maioria das publicações se dá em reuniões de grupos e subgrupos de estudo e o público dessas reuniões é que, de fato, aprova tais documentos. Mesmo que os Estados membros tenham a possibilidade de questionar tais documentos em instâncias superiores, é sempre constrangedor que alguém questione algo que já está aprovado e discutido por instâncias inferiores. Soma-se a isso a baixa capacidade de se questionar documentos dos quais um agente não participou de sua construção. Certamente a assimetria de informação favorece a aprovação do documento.

Há que se verifica também a participação de cada um dos agentes no financiamento da UIT. O orçamento para o período de 2016-2019 da UIT assim resume a participação financeira dos Estados, membros setoriais e outros atores $^{23}$ :

\footnotetext{
${ }^{23}$ Disponível em http://www.itu.int/dms pub/itu-s/opb/conf/S-CONF-ACTF-2014-PDF-E.pdf;
} 
Tabela 10 - Planejamento financeiro da UIT para 2016-2019.

\begin{tabular}{|c|c|c|c|c|}
\hline & $\begin{array}{l}\text { Orçamento } \\
2012-2013\end{array}$ & \begin{tabular}{|l|} 
Orçamento \\
$2014-2015$
\end{tabular} & $\begin{array}{l}\text { Estimativa } \\
2016-2017\end{array}$ & $\begin{array}{l}\text { Estimativa } \\
2018-2019\end{array}$ \\
\hline $\begin{array}{l}\text { Estados } \\
\text { Membros }\end{array}$ & 218.983 & 225.144 & 212.742 & 212.742 \\
\hline $\begin{array}{l}\text { Membros } \\
\text { Setoriais }\end{array}$ & 33.127 & 30.400 & 31.750 & 31.750 \\
\hline Associados & 3.409 & 3.411 & 3.910 & 3.910 \\
\hline Academia & 1.001 & 400 & 400 & 400 \\
\hline $\begin{array}{l}\text { Recuperação de } \\
\text { Custo }\end{array}$ & 57.100 & 65.500 & 67.250 & 67.250 \\
\hline $\begin{array}{l}\text { Juros e outras } \\
\text { receitas }\end{array}$ & 3.600 & 2.200 & 1.800 & 1.800 \\
\hline Conta de reserva & 6.614 & 4.000 & & \\
\hline $\begin{array}{l}\text { Estimativas de } \\
\text { receita }\end{array}$ & 323.834 & 331.055 & 317.852 & 317.582 \\
\hline Secretaria Geral & 179.169 & 184.971 & 181.233 & 184.148 \\
\hline UIT-R & 61.853 & 62.203 & 57.417 & 60.988 \\
\hline UIT-T & 26.200 & 25.529 & 25.658 & 24.797 \\
\hline UIT-D & 56.612 & 58.352 & 55.728 & 56.735 \\
\hline Total & 323.834 & 331.055 & 320.036 & 326.668 \\
\hline
\end{tabular}

Pela tabela, observa-se que a maioria do financiamento da UIT ainda é advindo dos Estados membros. Entretanto, a parcela relacionada aos membros setoriais não é negligenciável, situando-se em torno de $10 \%$.

\subsection{SOBRE A ANATEL}

Criada no governo FHC como uma das primeiras Agências Reguladoras brasileiras, a Anatel ficou responsável pela regulação do mercado basicamente privado após a privatização do sistema Telebrás.

O sistema de governança criado para o setor é relativamente simples, com o Ministério das Comunicações como o responsável pela formulação da política setorial e a Anatel como sua implementadora.

Vale lembrar que a Anatel foi criada para regular os serviços de telecomunicações que são prestados em dois regimes, o público e o privado. 0 
regime público, em que há mais controle estatal sobre as operações, é prestado mediante concessão, como controle tarifário e obrigações de continuidade e universalização. No regime privado, por sua vez, há maior liberdade para a ação dos agentes, tendo a competição como o grande responsável pela expansão dos serviços e de garantias de qualidade.

Essa percepção se refletiu inclusive na estrutura da Agência. A estrutura inicial da Anatel era baseada em sua em superintendências responsáveis por acompanhar e regular cada um dos serviços. No entanto, influenciada pelos fenômenos de convergência de serviço, em 2013, a estrutura da Agência foi alterada para estar voltada a processos, como se percebe do organograma atual:

Figura 9: Estrutura da Anatel.

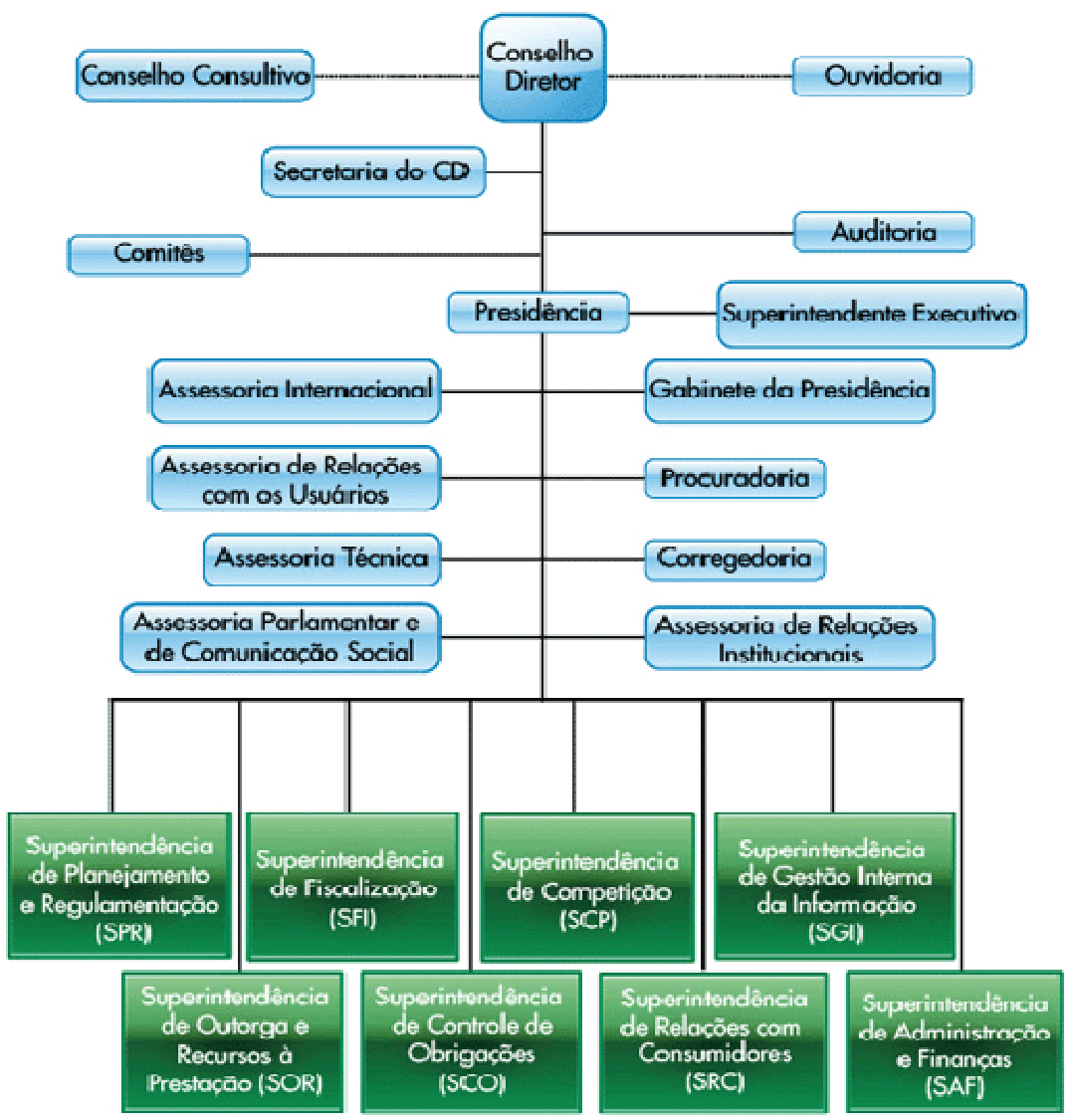

Fonte: Anatel.

\subsubsection{Questões internacionais}

Como se pode perceber, as questões internacionais têm um departamento específico na forma de Assessoria. Entretanto, as questões internacionais são acompanhadas institucionalmente por meio das CBCs 
(Comissões Brasileiras de Comunicações), que são as responsáveis pela formulação dos posicionamentos brasileiros nos fóruns internacionais.

O funcionamento das CBCs é regido por um Regimento Interno próprio, aprovado pela Resolução $n^{\circ} 347 / 2003^{24}$. De tal documento, destacam-se alguns aspectos:

- $\quad$ Estabelecimento de Grupo de Coordenação, o GC-CBC (Comitê Gestor das Comissões Brasileiras de Comunicações);

- $\quad$ Estabelecimento de mecanismo para aprovação de contribuições;

- Estabelecimento de obrigações para os coordenadores das CBCs, para a secretaria executiva do Grupo de Coordenação e para os participantes;

- $\quad$ Abertura à participação dos segmentos público e privado;

- Subordinação das CBCs às áreas tecnicamente afins na estrutura formal da Anatel;

- Mecanismos de tomada de decisão;

- $\quad$ Código de conduta dos participantes, que devem abrir mão se suas posições individuais em nome das posições da Administração brasileira.

Com tais regras, as CBCs tornaram-se entidades bastante plurais, com a participação de servidores da Anatel, de representantes do Ministério das Comunicações, de prestadoras, de fabricantes, de radiodifusores, bem como outros agentes. Por essa razão as CBCs têm necessidade de um mecanismo de governança, exercido pelo CG-CBC. Assim, a estrutura atual das CBCs pode ser representada da seguinte maneira ${ }^{25}$ :

\footnotetext{
${ }^{24} \mathrm{http}: / /$ www.anatel.gov.br/legislacao/resolucoes/2003/282-resolucao-347

${ }^{25}$ Estrutura descrita nas Resoluções Anatel $n^{\circ} 347 / 2003$ e 502/2008, disponíveis em: http://legislacao.anatel.gov.br/resolucoes/2003/282-resolucao-347 http://legislacao.anatel.gov.br/resolucoes/23-2008/286-resolucao-502
} 
Figura 10 - Estrutura das CBCs.

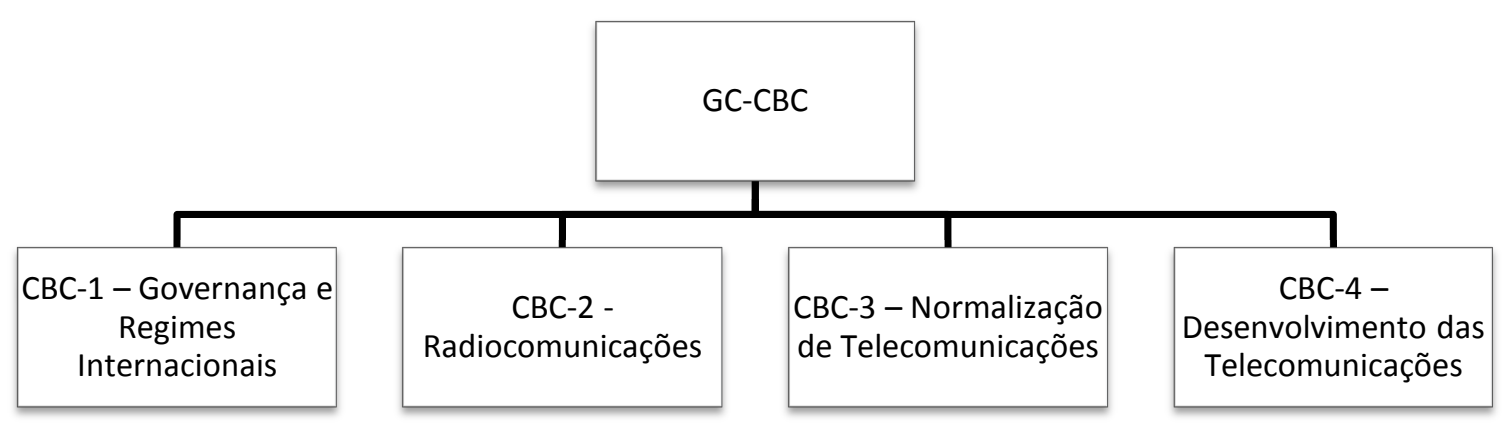

Fonte: elaborado pelo autor.

A estrutura das CBCs é praticamente paralela à estrutura da $U_{I}{ }^{26}$. Tal paralelismo existe também em parte da estrutura da Agência. Apesar de a estrutura permitir a participação por qualquer servidor da Agência, algumas áreas têm uma maior proximidade com os temas discutidos em âmbito internacional e seria natural que elas também participassem das respectivas CBCs. O paralelo é, então, o seguinte:

Tabela 11 - Paralelo entre os temas tratados pela UIT, a estrutura das CBCs e a estrutura da Anatel.

\begin{tabular}{|c|c|c|}
\hline Tema & CBC & $\begin{array}{c}\text { Superintendência/ } \\
\text { Assessoria }\end{array}$ \\
\hline $\begin{array}{c}\text { Governança e Regimes } \\
\text { Internacionais }\end{array}$ & CBC-1 & AIN \\
\hline Radiocomunicações & CBC-2 & SOR \\
\hline Normalização & CBC-3 & SPR \\
\hline Desenvolvimento & CBC-4 & - \\
\hline
\end{tabular}

Fonte: elaborado pelo autor.

\subsection{SOBRE RADIOCOMUNICAÇÕES E O ESPECTRO DE RADIOFREQUÊNCIAS}

A definição de radiocomunicações pode ser encontrada na Lei oㅡ 11.934/2009, que é a seguinte: telecomunicação que utiliza frequências radioelétricas não confinadas a fios, cabos ou outros meios físicos. Assim, estudar o arranjo institucional da área de radiocomunicações é estudar o arranjo institucional para produção de regulamentação de telecomunicações voltada para espectro de radiofrequências.

\footnotetext{
${ }^{26}$ A estrutura das CBCs antes de 2008 era diferente e bem mais fragmentada, mas era possível também perceber a correspondência entre uma CBC e um Bureau da UIT (UIT-T, UIT-R e UIT-D).
} 
Nesse sentido, vale mencionar que a Anatel é a entidade que tem a competência para administrar e expedir normas sobre o uso de espectro, de acordo com o inciso VIII do art. 19 da Lei Geral Telecomunicações. Entretanto, os serviços de radiodifusão continuam sendo regulamentados pelo Ministério das Comunicações e alguns aspectos relacionados ao serviço podem também trazer consequências para o uso de radiofrequências. Desta forma, vale fazer a ressalva de que, neste trabalho, só foi estudada a regulamentação editada pela Anatel, não se considerando regulamentações específicas para os serviços de radiodifusão editada, pelo Ministério das Comunicações.

O espectro de radiofrequências é um conceito que tem um caráter multifacetado, podendo ter três principais abordagens (PINHEIRO, 2015). A primeira delas é uma abordagem técnica, que enfoca os aspectos de engenharia do conceito. A segunda é uma abordagem econômica, a qual se apoia no entendimento do espectro como um recurso escasso. A terceira é uma abordagem jurídica, a qual tem diversas linhas argumentativas, dentre elas a de tratar o espectro como um bem público.

A abordagem técnica trata o espectro eletromagnético como um conjunto de todas as frequências contidas na radiação eletromagnética (MUSEY, 2013). A energia eletromagnética se propaga em formas de ondas e um dos principais atributos dessas ondas é a sua frequência. A frequência é então o número de oscilações ou ciclos em um determinado intervalo de tempo, que comumente é o segundo, gerando a unidade básica de medição de frequências, o Hertz $(\mathrm{Hz})$. Este parâmetro é importante porque reflete as principais características da onda, como a sua capacidade de propagação, sua atenuação, o que implica em sua aplicação nas comunicações, observação espacial, tratamentos médicos, etc. É bom mencionar que o espectro tratado neste trabalho não envolve todas as frequências existentes, mas sim as que são utilizadas para radiocomunicações e estão abaixo de $3000 \mathrm{GHz}$, conforme definição presente no Regulamento de Uso de Espectro, aprovado pela Resolução $n^{\circ} 259 / 2001^{27}$.

\footnotetext{
${ }^{27}$ http://www.anatel.gov.br/legislacao/resolucoes/2001/231-resolucao-259:

Espectro de radiofreqüências: bem público, de fruição limitada, cujo uso é administrado pela Agência, que corresponde a uma parte do espectro eletromagnético abaixo de $3000 \mathrm{GHz}$, que se propaga no
} 
A segunda abordagem é a econômica. Para essa abordagem, o espectro de radiofrequências é um bem escasso, renovável, rival e excludente, cuja regulação pode criar barreiras à entrada e gerar relevantes efeitos de rede no âmbito das telecomunicações (GRUBER, 2005; LEVIN, 2013). A escassez do espectro é uma das principais justificativas para sua regulação, uma vez que é entendida como uma barreira à entrada a mercados de radiocomunicação.

A renovabilidade do espectro está relacionada ao seu não desgaste com o uso. Essa característica é especialmente interessante no que se refere à destinação das faixas, uma vez ela pode ser alterada e, a priori, o uso por um serviço no passado não impede outras utilizações no futuro.

A rivalidade e a exclusividade estão relacionadas à impossibilidade de consumo de um bem quando alguém já o consumiu. Esse paradigma está relacionado à possibilidade de interferência, que impediria a utilização de uma faixa do espectro, caso alguém já a estivesse utilizando naquele mesmo instante e espaço geográfico. Apesar de esse paradigma estar mudando nos últimos tempos, essa característica está relacionada à proteção contra interferência, incluindo zonas de fronteira, cenário em que a UIT tem relevante papel.

No que se refere aos efeitos de rede (network effects), eles são caracterizados pelo aumento do interesse em determinado produto à medida que aumenta o número de consumidores daquele bem aumenta. No caso específico de espectro, essa externalidade é perceptível em relação aos ganhos de escala produzidos pelo aumento do número de usuários de determinado arranjo de frequências, o que induz à necessidade de padronização e harmonização. Apesar de a harmonização ser desejada em situações de externalidade, diferentes atores podem preferir diferentes padrões ou diferentes modos de construir padrões (ABBOTT e SNIDAL, 2001).

espaço sem guia artificial e que é, do ponto de vista do conhecimento tecnológico atual, passível de uso por sistemas de radiocomunicação; 
No campo jurídico, a abordagem mais comum sobre espectro é tratá-lo com um bem público limitado, como o faz o art. 157 da LGT $^{28}$. Apesar de a limitação citada no referido artigo ter sido bastante relativizada pelas evoluções tecnológicas, essa visão têm sido ainda o paradigma principal. Segundo esse paradigma, tais bens têm como a característica a inalienabilidade, a imprescindibilidade, a não-onerosidade e a impenhoraribilidade. Para garantir todas essas características, o espectro tem sobre si uma forte regulação do tipo "comando e controle", o que sofre críticas desde, pelo menos, o artigo seminal de Coase em 1959 (COASE, 1959).

Importante destacar que o escopo deste trabalho é estudar a destinação e a atribuição do espectro de radiofrequência e não outros aspectos, como a distribuição. Esses conceitos, apesar de parecerem próximos, trazem diferenças importantes, conforme definições presentes no Regulamento de Uso do Espectro de Radiofrequências, aprovado pela Anatel ${ }^{29}$ :

- Atribuição (de uma faixa de radiofrequências): inscrição de uma dada faixa de radiofrequências na tabela de atribuição de faixas de radiofrequências, com o propósito de usá-la, sob condições específicas, por um ou mais serviços de radiocomunicação terrestre ou espacial convencionados pela UIT, ou por serviços de radioastronomia;

- Destinação: inscrição de um ou mais sistemas ou serviços de telecomunicações - segundo classificação da Agência - no plano de destinação de faixas de radiofrequências editado pela Agência, que vincula a exploração desses serviços à utilização de determinadas faixas de radiofrequências, sem contrariar a atribuição estabelecida;

- Distribuição: inscrição de uma radiofrequência, faixa ou canal de radiofrequências para uma determinada área geográfica em um plano de distribuição editado pela Agência, sem contrariar a atribuição e a destinação estabelecidas.

A própria definição de destinação já remete à atribuição, a qual, por sua vez, está ligada aos serviços de radiocomunicações definidos pela UIT. Este

\footnotetext{
${ }^{28}$ Art. 157. O espectro de radiofreqüências é um recurso limitado, constituindo-se em bem público, administrado pela Agência.

${ }^{29}$ Resolução no 259, de 9 de abril de 2001 (http://www.anatel.gov.br/legislacao/resolucoes/2001/231resolucao-259)
} 
fato já mostra um grande vínculo do tema com a governança global, que é um dos temas centrais deste trabalho. Desta forma, aspectos ligados à realização de licitações de radiofrequências estão fora do escopo do presente estudo.

\subsubsection{A Regulamentação de Espectro de Radiofrequências}

Dentre as competências da Anatel, estabelecidas pela Lei Geral de Telecomunicações LGT), Lei $n^{\circ}$ 9.472/1998, está a de administrar o espectro de radiofrequências e o uso de órbitas, expedindo as respectivas normas. $O$ tema é tão relevante que ganhou um título inteiro (TíTULO V - Do Espectro e da Órbita), dentro do LIVRO III (Da Organização dos Serviços de Telecomunicações).

Dentre as disposições da lei, destaca-se o art. 158, que determina à Agência a manutenção de plano com a atribuição, distribuição e destinação de radiofrequências, em observância às atribuições de faixas segundo tratados e acordos internacionais. Além disso, no art. 161, há também a previsão de que a destinação de radiofrequências pode ser modificada para cumprimento de convenções ou tratados internacionais. Por reconhecer a importância da regulamentação internacional na regulamentação nacional, a lei também estabeleceu no rol de competências da agência a representação em organismos internacionais de telecomunicações, sob a coordenação do Poder Executivo.

Como se pode perceber, a regulamentação nacional de radiofrequências tem pontos de influência de regulamentações internacionais. Percebe-se também que, apesar da privatização do Sistema Telebrás promovida pela LGT, houve a manutenção no Estado de competências relacionadas à administração de radiofrequências. Tal processo, de maneira geral, não ocorreu de maneira muito diferente em outros países que, mesmo com diferentes arranjos institucionais para o setor de telecomunicações, mantiveram essa competência em entidades estatais.

A UIT, mencionada apenas uma vez na LGT no Capítulo sobre órbita e satélites, congrega diversos governos nacionais na discussão sobre uso de radiofrequências. Por conseguir reunir uma grande quantidade de Estados membros, com competência para administrar o espectro, a UIT se tornou o 
principal fórum mundial para discussão e harmonização de padrões para o uso de radiofrequência.

Importante mencionar que o desenho institucional utilizado pelo Brasil não é o único existente no mundo. Apenas a título exemplificativo, cita-se o caso da França e dos Estados Unidos da América. Ao contrário do Brasil, em que o regulador do mercado de telecomunicações é também o gestor da alocação de radiofrequências, nesses dois países (EUA e França), há mais de uma entidade para cumprir essas funções.

No caso da França, existe uma entidade específica que trata da gestão do espectro de radiofrequências, a ANFR (Agence Nationale des Fréquences) e outra entidade para regulação das comunicações eletrônicas e do setor postal, a ARCEP (Autorité de Régulation des Communications Életroniques et des Postes).

No caso dos EUA, as entidades são o NTIA (National Telecommunications and Information Administration) e o FCC (Federal Communications Commission) ${ }^{30}$. O NTIA ${ }^{31}$ é uma entidade do Departamento de Comércio, responsável pelo assessoramento da presidência sobre questões de telecomunicações e políticas públicas de informação, enquanto que o FCC é regulador do mercado de telecomunicações, bem como de radiodifusão.

Esta referência é apenas para observar que a escolha brasileira para gestão de espectro está relacionada à visão que se tem desse bem público. Ao se colocar a gestão de espectro dentro da estrutura do regulador de telecomunicações, estabelece-se um vínculo mais forte com esse setor do que com outras perspectivas. No caso americano, ao se vincular ao Departamento de Comércio, a NTIA traz uma visão de gestão de espectro para desenvolvimento econômico, com foco em inovação e desenvolvimento tecnológico. É uma perspectiva diferente da brasileira. No caso francês, uma entidade independente do regulador de telecomunicações separa os dois problemas e as esferas de influência recebidas por cada uma delas. Essa separação em mais de uma entidade pode levar a políticas incongruentes e a problemas de coordenação, entretanto, pode também trazer perspectivas mais variadas para a gestão do espectro de radiofrequências.

\footnotetext{
${ }^{30}$ https://www.fcc.gov/what-we-do

${ }^{31}$ http://www.ntia.doc.gov/about
} 


\subsubsection{Regulamentação de Espectro da Anatel}

A competência para regulamentação do espectro de radiofrequências, apesar de não se tratar somente de telecomunicações, foi atribuída à Anatel. A atribuição das faixas de frequências e sua organização para evitar interferências prejudiciais é uma das competências que não foi atribuída à iniciativa privada no processo de desestatização que ocorreu no Brasil. Nessa transição, ocorrida em especial na década de 1990, coube à Anatel esse papel no novo arranjo institucional que emergiu após a aprovação da Lei Geral de Telecomunicações de 1997.

Vale mencionar que existe aí um monopólio da União para regulamentação dessas questões. Assim como em outros setores da economia, como o monetário e o de aviação civil, é possível que os estados e municípios elaborem legislações complementares à Lei Geral aprovada pela União. No entanto, resta pouco espaço a ser ocupado por esses agentes subnacionais.

Mesmo em nível nacional, ao contrário de outros países, como EUA e França, o Brasil optou por um modelo em que uma única agência é responsável pela atribuição e regulamentação do espectro "comercial", quanto pelo espectro operado por agentes públicos, como Forças Armadas, Polícias e Bombeiros. Esse modelo centraliza na agência os pedidos e a influência de diversos agentes e partes interessadas (stakeholders) para defesa de seus interesses, sejam eles agentes públicos/estatais ou privados.

A construção de regulamentação está, então, sujeita a diversas influências, tanto de agentes públicos, como de agentes privados. Essas influências, à parte de audiências, seminários e reuniões promovidas pelas partes interessadas ou pela agência, podem ser também materializadas por meio de consultas públicas.

Por força da lei de sua criação, a Anatel é obrigada a submeter as minutas de regulamentação a consulta pública. Após realização da consulta pública e a contribuição pelos interessados naquele assunto, o tema é reavaliado pela agência, que, então, aprova a versão final da regulamentação. Essa sistemática mais dá transparência para a ação da Anatel, uma vez que durante a consulta pública ficam mais claros os agentes que influenciam no 
processo e seus pontos de vista. Além disso, após a aprovação da regulamentação, a Anatel publica comentários sobre a regulamentação, justificando sua posição final. Esses comentários são valiosos instrumentos para a prestação de contas (accountability) da agência.

\subsubsection{Instrumentos regulatórios}

O principal instrumento para aprovação de regulamentação da Anatel é por meio de Resoluções de seu Conselho Diretor. As normas e regulamentos aprovados por essas resoluções estabelecem condições de uso de determinadas faixas de frequência. Por esta razão, de maneira geral, os regulamentos detalham questões específicas para determinadas faixas de frequência.

Entretanto, não se pode esquecer de resoluções importantes que não estão vinculadas a algum espectro específico, mas a toda a gestão de espectro. São exemplos dessas regulamentações, os seguintes regulamentos: Regulamento de Uso do Espectro de Radiofrequências ${ }^{32}$, Regulamento sobre Equipamentos de Radiocomunicação de Radiação Restrita ${ }^{33}$, Regulamento para Avaliação da Eficiência de Uso do Espectro de Radiofreqüências ${ }^{34}$, dentre outras.

Os Planos de Atribuição, Destinação e Distribuição de Faixas de Frequências (PDFF) ${ }^{35}$ são também instrumentos importantes para a gestão do espectro. Tais instrumentos são a compilação das atribuições e destinações de espectro realizadas pela Anatel. Como ele é norteado para o cumprimento de tratados internacionais ${ }^{36}$, estão presentes referências a atribuição de radiofrequência na Região 2 , bem como as notas de rodapé relevantes do Radio Regulations para cada faixa de frequência. Inicialmente aprovados por meio de Resolução do Conselho Diretor da Anatel, esses instrumentos passaram a ser posteriormente aprovados por um Ato do Conselho Diretor.

Outros instrumentos importantes para a regulação de espectro são os editais de licitação de radiofrequência. Esses instrumentos possibilitam a

\footnotetext{
${ }^{32}$ Resolução no 259, de 19 de abril de 2001.

${ }^{33}$ Resolução no 506, de 10 de julho de 2008.

${ }^{34}$ Resolução no 548, de 8 de novembro de 2010.

${ }^{35}$ O Plano de Atribuição, Destinação e Distribuição de Faixas de Frequências brasileiro pode ser consultado em http://sistemas.anatel.gov.br/pdff/

${ }^{36}$ Lei Geral de Telecomunicações, Lei n. 9472/1997, art. 158.
} 
escolha dos agentes econômicos que farão uso do espectro e estabelecem também regras para sua ocupação. Dentre as importantes regras que são estabelecidas nesses instrumentos estão o preço mínimo a ser pago pelos vencedores do certame, compromissos de abrangência, condições de ressarcimento a agentes impactados por possível desocupação da faixa, dentre outros. Como exemplos desses editais de licitação, pode-se citar o "Edital 3G"37, o "Edital 4G"38 e o Edital para a faixa de $700 \mathrm{MHz}$.

Depois de feita uma licitação, um chamamento público ou um pedido para autorização de uso de radiofrequência, o interessado recebe sua autorização por meio de dois instrumentos, um Ato e um Termo de Autorização. Esses documentos materializam e declaram que aquela porção do espectro pode ser utilizada por aquele agente e em que condições, se em caráter primário, secundário, em que área e outros compromissos eventualmente assumidos.

A fiscalização exercida pela Anatel também pode ser entendida como um instrumento regulatório. Essa atividade proporciona enforcement das regras, restabelecimento do serviço em caso de interferência prejudicial e a harmônica convivência entre os diversos serviços e os diversos utilizados de espectro, considerado um bem público.

Esses diferentes instrumentos são complementares em suas funções regulatórias, bem como procedimentos administrativos específicos. Eles estão encadeados de maneira a formar um fluxo que se inicia na destinação do espectro a determinado serviço ou aplicação, passa pela definição das condições de uso, pela consignação de blocos ao agente que irá operar seus sistemas e, por fim, com o licenciamento das estações e fiscalização pela Anatel. Cada uma dessas fases têm agentes e dinâmicas distintas que merecem ser estudadas individualmente.

\subsubsection{Princípio de neutralidade tecnológica na alocação de espectro}

O princípio da neutralidade tecnológica é um corolário do princípio de isonomia aplicado à regulação de radiofrequências. A regulação, por constranger a ação dos atores, pode dar alguma vantagem indevida a algum

\footnotetext{
${ }^{37}$ Edital de Licitação no 2/2007/SPV.

${ }^{38}$ Edital de Licitação no 4/2012/PVCP/SPV-Anatel.

${ }^{39}$ Edital de Licitação no 2/2014-SOR/SPR/CD-ANATEL.
} 
arranjo tecnológico. Por esta razão, o uso do princípio da neutralidade tecnológica tem sido incentivado para gestão de espectro (RYAN, 2005).

A preocupação principal com a gestão do espectro é permitir a convivência harmônica entre os serviços. Evitar interferência é, portanto, um dos valores fundamentais a serem buscados. Para isso, devem ser conhecidas as características de transmissão e recepção dos equipamentos, bem como o meio em que os sinais estão sendo propagados. Esses parâmetros são básicos e, na grande maioria das vezes, não estão relacionados a particularidades tecnológicas dos sistemas em operação.

Essa característica reduz a regulamentação de espectro a aspectos essenciais para a garantia de convivência harmônica e eficiente entre os sistemas. Em compensação, em algumas situações, surgem questões de interoperabilidade que não são tratadas devido a esse princípio. Um exemplo é o sistema de telefonia celular. Durante algum tempo, as prestadoras utilizavam tecnologias diferentes sob o mesmo espectro, o que impedia que um determinado usuário pudesse utilizar seu terminal em outra rede. Naturalmente essas dificuldades foram suplantadas pelo aumento do número de protocolos suportados pelos terminais, mas demonstra que tecnologias distintas podem atender a regulamentação de espectro sem que essa trate de aspectos específicos de uma tecnologia ou outra.

A regulamentação não baseada em tecnologias tende também a ser mais estável. Com o não tratamento de aspectos específicos da tecnologia, o regulador tem segurança de que sua regulamentação está atualizada e que ele não está impedindo alguma evolução tecnológica. A estabilidade nas regras dá credibilidade ao regulador, trazendo confiança ao investidor que, ao não perceber mudanças constantes, entende o ambiente como previsível e em melhores condições para receber investimentos.

Apesar de a regulamentação se pautar pela neutralidade, algumas tecnologias são desenvolvidas para operação em porções específicas do espectro de radiofrequência. Por esta razão, em algumas situações, a adoção de determinado serviço para determinado espectro implica também em uma decisão tecnológica, apesar de ela (regulamentação) não mencionar nada 
sobre tecnologia. A neutralidade, na prática, é tão difícil de se alcançar (REED, 2007), quanto a independência do regulador (STIGLER, 1971).

A adoção do princípio da neutralidade tecnológica é também um desdobramento da autonomia exigida de uma agência reguladora. Um dos objetivos da desregulação do setor de telecomunicações foi propiciar a inovação e o desenvolvimento tecnológicos, princípio presente no art. $2^{\circ} \mathrm{da}$ LGT. O estabelecimento de tecnologias em regulamentação estatal poderia inibir a evolução tecnológica, bem como limitar a competição entre os desenvolvedores.

Situação diferente existia quando o Estado era provedor de serviços. Para prestar um serviço de telecomunicações, a prestadora deve escolher as tecnologias que melhor atendem a seus interesses, bem como os fornecedores de tais soluções tecnológicas. O prestador é obrigado a fazer uma escolha. $\mathrm{Na}$ condição de regulador, o Estado não precisa tomar essa decisão, que continua nas mãos do prestador de serviços, agora privado.

Interessante observar que essa lacuna regulamentar sobre quais protocolos e tecnologias devem ser adotadas abre uma arena de disputas entre os fornecedores tecnológicos não mediada pelo Estado. Isso fez com que se ampliassem os fóruns privados de discussão de padronização e de definição de protocolos de comunicação.

\subsubsection{O ecossistema de regulamentação relacionada a radiocomunicações}

Conforme mencionado anteriormente, o papel central dos Estados na prestação de serviços de telecomunicações foi alterado com a desregulação do setor. Esse fenômeno, ocorrido em escala mundial, alterou também as redes de relacionamento formadas por estes Estados, dentre as quais se destaca a UIT.

Com o afastamento do Estado da condição de prestador de serviços e o aumento das necessidades de envolvimento de agentes privados, especialmente as prestadoras, adaptações nas relações começaram a ser feitas. A primeira delas foi uma alteração na dinâmica da UIT, possibilitando maior participação de agentes privados. O segundo foi o surgimento e 
fortalecimento de fóruns privados de discussão e padronização. São exemplos desses fóruns, a GSMA e o 3 GPP.

Esse novo ecossistema teve impacto direto na forma de regulação do espectro. A regulamentação estatal passou a restringir-se mais a aspectos relacionados a gestão de espectro (prevenção de interferência e convivência harmônica entre os serviços), enquanto que a padronização de protocolos (modulação, codificação, etc) foi deixada a cargo da iniciativa privada.

\subsubsection{Agentes e seus interesses}

De modo a poder compreender melhor quais os interesses que permeiam as influências sobre o regulador de telecomunicações brasileiro, é importante fazer um levantamento dos principais agentes que podem exercer tal influência.

Os próprios regulados são um desses agentes. De maneira geral, as prestadoras tendem a rejeitar qualquer imposição de obrigações que thes onere. Por exemplo, regulamentações que falam de direitos dos consumidores, ou obrigações de expansão de rede são mal vistas por esses agentes, por thes imputar custos que, possivelmente, não seriam incorridos se não fosse a regulamentação. Entretanto, existem situações em que as prestadoras têm interesses antagônicos, por serem competidoras num mesmo mercado. Regulamentações que geram assimetrias para equalização da competição entre prestadoras com diferentes capacidade de influir no mercado são um exemplo de regulamentações que geram interesses divergentes entre as prestadoras.

No que se refere a políticas regulatórias, no sentido de (LOWI, 1972), e que não têm um caráter redistributivo, como é o caso das padronizações de protocolos ou de radiofrequências, seria esperado um comportamento neutro ou no sentido de harmonização mundial para aumento de escala e diminuição dos preços dos insumos. No caso brasileiro, isso se reveste de peculiar interesse.

Conforme mencionado anteriormente, o Brasil não é um país desenvolvedor de tecnologias de telecomunicações, mas sim um seguidor. Dessa forma, os grandes conglomerados econômicos internacionais, muitas vezes, já fizeram suas opções tecnológicas em outras regiões do mundo e 
seria interessante para eles que o mesmo padrão, arranjo de radiofrequências ou outras características técnicas fossem adotadas pelo Brasil. Essa conjuntura faz com que haja pressão também por parte das prestadoras no sentido de harmonizar a regulamentação técnica brasileira com os padrões mundiais ou semimundiais adotados pela sede do grupo econômico.

Além das prestadoras, existe outro tipo de agente que é também impactado, apesar de não ser um ente regulado. Esses agentes são os fabricantes de equipamentos e desenvolvedores de tecnologia. Em muitas circunstâncias, a regulamentação pode induzir escolhas tecnológicas por parte de agentes regulados (prestadoras), especialmente por meio de dois mecanismos: certificação de equipamentos e destinação de faixas de radiofrequência.

Apesar de as regulamentações sobre certificação de equipamentos serem tecnologicamente isonômicas, algum critério pode não ser atendido por determinado fabricante, eliminando-o do rol de possibilidades.

No caso de regulamentações de destinação e uso de radiofrequência, a escolha de determinada radiofrequência para algum serviço ou as condições de uso podem facilitar a escolha pelos agentes regulados de alguma tecnologia. Por essa razão, fabricantes de equipamentos e desenvolvedores de tecnologia têm grande interesse nas regulamentações editadas pela Anatel. Especialmente num contexto em que há efeitos de rede, conforme mencionado anteriormente, a escolha de um padrão significa a possibilidade de entrada em um mercado que pode crescer ou o completo alijamento do mercado. Importante mencionar que uma das características desse agente (fabricante) é o grande conhecimento do negócio e da tecnologia, tendo uma assimetria de informação a seu favor em relação ao regulador.

No caso do Governo, ao menos dois interesses podem ser percebidos mais claramente. O primeiro é o desenvolvimento de políticas públicas que estejam de acordo com seu plano de governo. É de interesse do Governo que o ente regulador desenvolva suas atividades de modo a cumprir metas e promessas de campanha, ou de fornecer bons indicadores sobre uma determinada administração. O outro ponto refere-se à arrecadação. Um dos interesses do Governo é maximizar a sua receita e é importante observar que 
as agências reguladoras recolhem diversas taxas. No caso do setor de telecomunicações, destacam-se a seguintes: FUST, FISTEL e FUNTTEL. Assim como no caso dos fabricantes e prestadoras, o Governo também não é um agente uniforme. Pode haver interesses diversos de acordo com as visões e prioridades de cada órgão ou entidade.

Outro agente com interesse na regulamentação é a sociedade civil. O interesse desse agente está especialmente relacionado à diminuição dos preços e o aumento da proteção dos direitos dos consumidores. Assim, a pressão desses agentes é no sentido de aumentar a intervenção do regulador no mercado, o que é diametralmente oposto ao interesse das empresas (prestadoras), especialmente as com mais poder de mercado. Os agentes da sociedade civil, de maneira geral, não têm possibilidade de conduzir estudos técnicos que possam contestar as argumentações mais sofisticadas do regulador e de empresas. Desta forma, a participação mais significativa desses agentes é por meio de associações e entidades civis, que conseguem diminuir a assimetria informacional e apresentar argumentações mais robustas.

Por fim, alguns agentes muitas vezes negligenciados, por não serem entes regulados, são os organismos internacionais. Entretanto, esses agentes têm o interesse de ver seus padrões serem, de fato, ratificados por seus Estados membros. A aceitação de seus padrões pelos países é um indício de sucesso da atuação do organismo internacional, já que ele tem o objetivo de harmonizar padrões, facilitando o intercâmbio entre os países e diminuindo as chances de incompatibilidade. No entanto, o desenvolvimento de padrões por esses agentes está também sujeito a influências pelos desenvolvedores de tecnologia, assim como as agências reguladoras nacionais. Essas organizações são arenas de debate em que requisitos e padrões tecnológicos são discutidos, incluindo a atribuição de faixas de radiofrequência. Assim, existe também uma assimetria de conhecimento nas ações desenvolvidas dentro dos organismos internacionais. Essa assimetria favorece países e conglomerados econômicos com maior conhecimento tecnológico, bem como com maiores possibilidades de pautar e executar os trabalhos dentro do organismo internacional. 


\section{METODOLOGIA}

\subsection{SOBRE O MÉTODO A SER UTILIZADO}

O método de pesquisa utilizado neste trabalho é o estudo de caso. Segundo Yin (2015), a escolha do método de pesquisa consiste em analisar 3 condições:

- O tipo de questão de pesquisa proposto;

- A extensão do controle que um pesquisador tem sobre eventos comportamentais reais;

- O grau de enfoques sobre eventos contemporâneos em oposição aos eventos totalmente históricos.

A tabela abaixo resume os métodos adequados de acordo com cada uma das condições descritas

Tabela 12 - Situações para cada tipo de método de pesquisa.

\begin{tabular}{|l|l|l|l|}
\hline \multicolumn{1}{|c|}{ MÉTODO } & $\begin{array}{c}\text { Forma de questão } \\
\text { de pesquisa }\end{array}$ & $\begin{array}{c}\text { Exige controle de } \\
\text { eventos } \\
\text { comportamentais? }\end{array}$ & $\begin{array}{l}\text { Enfoca eventos } \\
\text { contemporâneos? }\end{array}$ \\
\hline Experimento & Como, por quê? & Sim & Sim \\
\hline $\begin{array}{l}\text { Levantamento } \\
\text { (survey) }\end{array}$ & $\begin{array}{l}\text { Quem, o quê, onde, } \\
\text { quantos, quanto? }\end{array}$ & Não & Sim \\
\hline Análise de arquivos & $\begin{array}{l}\text { Quem, o quê, onde, } \\
\text { quantos, quanto? }\end{array}$ & Não & Sim/Não \\
\hline Pesquisa histórica & Como, por quê & Não & Não \\
\hline Estudo de caso & Como, por que? & Não & Sim \\
\hline
\end{tabular}

Fonte: Yin (2015).

Neste estudo, deseja-se saber quais fatores podem influenciar as Agências Reguladoras, o que seguramente leva a perguntas como: quem são os atores envolvidos? Quais os métodos utilizados por eles? Como e por quê fazem isso? Nesse sentido, o método tem que ir além de uma análise de arquivos, que não pode responder questões do tipo como e por quê. Além disso, o objeto de estudo é um evento contemporâneo, já que a alteração de destinação de radiofrequências é um processo contínuo que acontece à medida que surgem novas necessidades, aplicações e tecnologias.

A contemporaneidade permite adicionar duas técnicas de pesquisa, a observação direta e as entrevistas. A observação direta é utilizada neste 
trabalho, uma vez que acontecimentos posteriores às consultas públicas (vide seção 3.4) são utilizados como fontes de evidência. Entretanto, a técnica de entrevista não é utilizada neste trabalho.

\subsection{RECORTE DE PESQUISA}

Para se avaliar a influência de organizações internacionais em agências reguladoras nacionais, várias podem ser as alternativas. De maneira geral, duas estratégias poderiam ser consideradas. Uma em que o escopo e o número de casos são maiores, ou seja, são estudadas agências reguladoras e organizações internacionais de diversos setores. Outra em que o número de casos e o escopo são reduzidos, possibilitando o aprofundamento do estudo para melhor compreensão de mecanismos causais.

No presente estudo, são consideradas como organizações internacionais apenas as agências especializadas do Sistema ONU, mas, de maneira similar, podem ter sido consideradas agências de outras naturezas, como ONGs transnacionais, associações internacionais, dentre outros arranjos. No entanto, preferiu-se se ater às agências especializadas do Sistema ONU. Nelas, os países (Estados) têm representação, o que pode enriquecer o aprendizado no sentido de que os Estados são ao mesmo tempo influenciadores na esfera internacional e influenciados na esfera nacional. No caso de associações, elas geralmente não envolvem agentes estatais e as influências geradas por elas não teriam um mecanismo de funcionamento muito diferente de outros agentes privados. Nesse sentido, o estudo dos fóruns privados possivelmente tem um menor potencial de agregar conhecimento acadêmico.

No que se refere ao alcance da pesquisa, se ela deve abranger diversos setores por meio de comparações ou se ater a um menor escopo, opta-se por um escopo mais reduzido. Essa escolha deve-se ao fato da grande variedade de agências reguladoras brasileiras e de agências especializadas da ONU. A tabela abaixo resume os setores em que há a presença desses tipos de organizações: 
Tabela 13 - Correspondência entre as agências reguladoras brasileiras e as agências especializadas da ONU.

\begin{tabular}{|c|c|c|}
\hline Setor & $\begin{array}{ll}\text { Agência } & \text { Reguladora } \\
\text { Vinculada } & \end{array}$ & Agência ONU ${ }^{40}$ \\
\hline Telecomunicações & $\begin{array}{l}\text { Anatel - Agência Nacional de } \\
\text { Telecomunicações }\end{array}$ & $\begin{array}{ll}\text { União Internacional } & \text { de } \\
\text { Telecomunicacõos (ITU) } & \end{array}$ \\
\hline Aviação Civil & $\begin{array}{l}\text { ANAC - Agência Nacional de } \\
\text { Aviacão Civil }\end{array}$ & $\begin{array}{l}\text { Organização Internacional da } \\
\text { Aviação Civil (ICAO) }\end{array}$ \\
\hline Saúde & $\begin{array}{l}\text { Anvisa - Agência Nacional de } \\
\text { Vigilância Sanitária }\end{array}$ & $\begin{array}{lll}\text { Organização } & \text { Mundial } & \text { da } \\
\text { Saúde (WHO) } & & \end{array}$ \\
\hline $\begin{array}{l}\text { Navegação } \\
\text { Transportes } \\
\text { Aquaviários } \\
\end{array}$ & $\begin{array}{lr}\text { Agência } & \text { Nacional de } \\
\text { Transportes } & \text { Aquaviários } \\
\text { (Antaq) } & \\
\end{array}$ & $\begin{array}{ll}\text { Organização } & \text { Internacional } \\
\text { Marítima (IMO) } & \end{array}$ \\
\hline $\begin{array}{l}\text { Segurança } \\
\text { Alimentar }\end{array}$ & - & $\begin{array}{l}\text { Organização das Nações } \\
\text { Unidas para Alimentação e } \\
\text { Agricultura (FAO) }\end{array}$ \\
\hline $\begin{array}{l}\text { Segurança } \\
\text { Alimentar }\end{array}$ & - & $\begin{array}{lr}\text { Fundo Internacional } & \text { para } \\
\text { Desenvolvimento } & \mathrm{da} \\
\text { Agricultura (IFAD) } & \\
\end{array}$ \\
\hline Trabalho & - & $\begin{array}{l}\text { Organização Internacional do } \\
\text { Trabalho (ILO) }\end{array}$ \\
\hline $\begin{array}{l}\text { Desenvolvimento } \\
\text { econômico }\end{array}$ & - & $\begin{array}{ll}\text { Fundo } & \text { Monetário } \\
\text { Internacional (IMF) }\end{array}$ \\
\hline $\begin{array}{l}\text { Desenvolvimento } \\
\text { econômico }\end{array}$ & - & $\begin{array}{l}\text { Grupo Banco Mundial: } \\
\text { - Banco Internacional para } \\
\text { Reconstrução } \\
\text { Desenvolvimento (IBRD) } \\
\text { - Centro Internacional para } \\
\text { liquidação de disputas de } \\
\text { investimentos (ICSID) } \\
\text { - Associação Internacional de } \\
\text { Desenvolvimento (IDA) } \\
\text { - Corporação Financeira } \\
\text { Internacional (IFC) } \\
\text { - Agência para Garantia } \\
\text { Multilateral } \\
\text { Investimentos (MIGA) }\end{array}$ \\
\hline $\begin{array}{l}\text { Desenvolvimento } \\
\text { industrial }\end{array}$ & - & $\begin{array}{l}\text { Organização das Nações } \\
\text { Unidas para Desenvolvimento } \\
\text { Industrial (UNIDO) }\end{array}$ \\
\hline Setor Postal & - & União Postal Universal (UPU) \\
\hline $\begin{array}{l}\text { Ciência, educação } \\
\text { e cultura }\end{array}$ & - & $\begin{array}{l}\text { Organização das Nações } \\
\text { Unidas para Educação, } \\
\text { Ciência e Cultura (UNESCO) }\end{array}$ \\
\hline $\begin{array}{l}\text { Propriedade } \\
\text { intelectual } \\
\text { (patentes) }\end{array}$ & - & $\begin{array}{l}\text { Organização Mundial de } \\
\text { Propriedade } \\
\text { Intelectual (WIPO) }\end{array}$ \\
\hline Meteorologia & - & $\begin{array}{l}\text { Organização Mundial } \\
\text { Meteorologia (WMO) }\end{array}$ \\
\hline Turismo & - & $\begin{array}{l}\text { Organização Mundial } \\
\text { Turismo (UNWTO) }\end{array}$ \\
\hline
\end{tabular}

\footnotetext{
${ }^{40}$ Referência: http://www.un.org/en/aboutun/structure/index.shtml
} 


\begin{tabular}{|l|l|l|}
\hline Setor & $\begin{array}{l}\text { Agência Reguladora } \\
\text { Vinculada }\end{array}$ & Agência ONU ${ }^{40}$ \\
\hline $\begin{array}{l}\text { Petróleo, gás } \\
\text { natural } \\
\text { biocombustíveis e }\end{array}$ & $\begin{array}{l}\text { Agência Nacional de Petróleo } \\
\text { (ANP) }\end{array}$ & - \\
\hline Energia Elétrica & $\begin{array}{l}\text { Agência Nacional de Energia } \\
\text { Elétrica (Aneel) }\end{array}$ & - \\
\hline Planos de saúde & $\begin{array}{l}\text { Agência Nacional de Saúde } \\
\text { Suplementar (ANS) }\end{array}$ & - \\
\hline Recursos hídricos & $\begin{array}{l}\text { Agência Nacional de Águas } \\
\text { (ANA) }\end{array}$ & - \\
\hline $\begin{array}{l}\text { Fomento de de Necional do Cinema } \\
\text { produções } \\
\text { audiovisuais }\end{array}$ & $\begin{array}{l}\text { Agência Nacion } \\
\text { (Ancine) }\end{array}$ & - \\
\hline $\begin{array}{l}\text { Transportes } \\
\text { terrestres }\end{array}$ & $\begin{array}{l}\text { Agência Nacional dos } \\
\text { Transportes Terrestres (ANTT) }\end{array}$ & - \\
\hline
\end{tabular}

Fonte: elaborado pelo autor.

Foram listadas apenas agências especializadas da ONU para algum setor, pois organismos como a Agência Internacional de Energia Atômica (IAEA) ou a Organização Mundial do Comércio (WTO) não têm paralelo com agências reguladoras brasileiras.

Outro fato que deve ser destacado é que na coluna de Agência Reguladora Vinculada há algumas células vazias. Isso não significa que não exista uma entidade na administração pública brasileira que esteja vinculada àquele setor. Certamente há, mas essa entidade não foi criada segundo o arranjo de uma agência reguladora, por isso não foi mencionada.

Desta forma, o recorte é possível para aquelas agências que têm seus pares no sistema ONU: Anatel - ITU; ANAC - ICAO; Anvisa - WHO; AntaqIMO.

Apesar disso, entende-se que o caso da Antaq deve ser excluído, uma vez que no arranjo brasileiro, grande parte das competências na relação com a IMO são exercidas pela Marinha do Brasil, fugindo ao escopo do presente trabalho que enfoca as agências reguladoras. Os casos da ANAC e Anvisa são casos que poderiam também ser estudados, mas, a fim de poder aprofundar mais na análise, optou-se pelo caso da Anatel-ITU.

Com isso visa-se também controlar por variáveis que são heterogêneas entre os setores, como o domínio tecnológico. Por exemplo, no setor de aviação civil, o Brasil é um dos expoentes internacionais, tanto por possuir um importante mercado interno, como por possuir importantes companhias aéreas e fabricantes (Embraer é o maior representante dessa indústria). No caso do 
setor de telecomunicações, a situação é distinta. Apesar de o Brasil possuir também um importante mercado interno, seu domínio tecnológico é bastante inferior do que no setor de aviação civil, o que deixa o setor de telecomunicações mais susceptível a influências externas.

Mesmo restringindo-se ao caso Anatel-ITU, ele ainda é ainda bastante amplo e pouco uniforme. Basta lembrar que a regulamentação nacional trata de questões muitas vezes não tratadas pela UIT, como direitos dos usuários e sistemas de licenciamento de serviços e estações. Assim, busca-se avaliar um subconjunto de assuntos dentro da regulamentação setorial de telecomunicações.

Mais uma vez, uma opção é feita. Neste caso, opta-se por estudar a regulamentação relativa ao espectro de radiofrequências, por esse ser um caso que poderá trazer mais ganhos de conhecimento acadêmico. Outras opções seriam estudar os regulamentos dos serviços, questões relacionadas à certificação de produtos ou questões de regulação econômica.

A opção pelo tema de radiocomunicações se deve à maior uniformidade do tratamento dessas questões na regulamentação. Em geral, questões relativas a radiofrequência são tratadas em regulamentos específicos, diferentemente de outras questões, que muitas vezes são tratadas em regulamentos mais amplos e de difícil isolamento. Outro aspecto que induz à escolha desse tipo de regulamentação é o fato de haver dentro da UIT uma divisão específica (ITU-R) para esse tema. As outras divisões da UIT (ITU-T: Padronização e ITU-D: Desenvolvimento) têm características bastante distintas, em especial por não possuírem um instrumento com status de tratado, como o Radio Regulations.

Além dos fatos relatados, há hoje muito questionamento sobre o papel da UIT em relação à "Governança da Internet". Este tema, emergente após a popularização da Internet, tem vários fóruns de discussão, como a ICANN (Internet Corporation for Assigned Names and Numbers), o IETF (Internet Engineering Task Force) e o IGF (Internet Governance Forum), que, assim como a UIT, faz parte do sistema ONU. Essa discussão refere-se, em especial, ao papel dos Estados nacionais nessa regulação. Entretanto, no que se refere a gestão de espectro, os Estados nacionais e a UIT permanecem com tal 
atribuição, o que torna este recorte (regulamentação de espectro de radiofrequências) bastante aderente ao que se pretende pesquisar.

Ainda dentro deste tema, uma destinação de uso de espectro específica poderia ser escolhida para seu estudo aprofundado. Entretanto, essa opção levaria a um estudo de alcance mais restrito, com uma situação bastante particular e com baixa capacidade de generalização. Por esta razão, entendese que estudar todo o conjunto de regulamentações de radiofrequência, desde a criação da Anatel, pode fornecer o equilíbrio necessário entre o aprofundamento necessário e a possibilidade de criação de hipóteses com maior capacidade de generalização.

\subsection{PERGUNTA DE PESQUISA E HIPÓTESES}

Com base no que descrevem as referências teóricas, a difusão do capitalismo global faz com que haja reprodução de algumas formas de governança, como é o caso de agências reguladoras independentes (RIA Regulatory Independent Agency - Agência Reguladora Independente).

A influência internacional na criação desse tipo de organismo (RIA) é bastante estudada, conforme já mencionado, mas poucos são os estudos sobre a continuidade da influência internacional depois que as agências foram criadas. Será que essas influências permanecem? As formas para a sua ocorrência foram alteradas? Essas são questões que surgem com a evolução do modelo regulatório no Brasil e no mundo.

No presente estudo, foram consideradas questões específicas do caso estudado, mas que podem ser reformuladas e estendidas para outras situações. Não se pretende que o caso estudado possa ter suas conclusões extrapoladas para outros casos, contudo, essa formulação proporciona que estudos futuros possam comprovar ou refutar as conclusões e resultados encontrados neste trabalho. Isso proporciona a oportunidade de construção de uma agenda de pesquisa mais ampla que não se limita apenas ao presente estudo.

Desta forma, a pergunta de pesquisa é formulada da seguinte maneira:

Qual a influência da UIT nas tomadas de decisão da Anatel sobre radiocomunicações? 
No presente caso, conforme já mencionado, restringiu-se o estudo ao setor de telecomunicações, especificamente às regulamentações relativas ao espectro de radiofrequências (radiocomunicações).

Para resposta de tal pergunta de pesquisa, há a hipótese a ser testada, que é a seguinte:

H1: A UIT tem uma influência relevante na regulamentação de radiocomunicações editada pela Anatel.

Uma questão relevante em relação a essa hipótese é o que se entende por "relevante". A UIT, conforme considerada neste estudo, é um agente. Assim, o que se pretende avaliar é se a UIT, na condição de uma agência especializada da ONU, é um agente relevante, ante os demais identificados na literatura clássica sobre regulação, como o Governo, Sociedade e mercado regulado.

Como se pode perceber, no presente caso, a UIT é compreendida como um agente facilitador da difusão de políticas públicas. Portanto, ao se tentar compreender a relevância da UIT, será também avaliada a possível influência de outros agentes.

Caso a hipótese de influência relevante da UIT seja confirmada, investigações adicionais serão conduzidas para descrever o mecanismo dessa influência. Essa influência será problematizada de acordo com os interesses dos agentes, descritos anteriormente, de modo a testar a hipótese de a UIT ser utilizada como intermediária por algum orquestrador. Essa questão leva a uma hipótese secundária:

H1.1: A UIT é utilizada como intermediária por orquestradores.

$\mathrm{Na}$ aplicação do modelo de orquestração, Abbott (2015) já lança uma série de premissas e hipóteses gerais para orquestração (vide seção 1.3.4) e essas premissas e hipóteses gerais servem de base para a resposta da pergunta de pesquisa. 
3.4 BASES DE DADOS: RESOLUÇÕES, CONSULTAS PÚBLICAS E CONTRIBUIÇÕES

Para a busca de evidências empíricas, são utilizados documentos publicados pela Anatel, como as resoluções, bem como as oportunidades em que há documentos públicos de interação da agência com a sociedade. Assim, serão utilizadas as seguintes bases de dados:

- Resoluções;

- Consultas públicas;

- Contribuições.

\subsubsection{Resoluções}

As resoluções da Anatel são os instrumentos utilizados pela agência para aprovação de atos normativos. Por meio de Resoluções, são aprovados regulamentos, planos e normas. No caso específico de radiocomunicações, a competência para aprovação de planos de destinação de faixas de radiofrequências e de ocupação de órbitas cabe ao Conselho Diretor.

Assim, as resoluções são assinadas pelo Presidente do Conselho Diretor da Agência e prestam-se a aprovar regulamentos, geralmente como anexos do texto principal, bem como destinações e atribuições diretamente no corpo da Resolução.

Percebe-se também que, no início do funcionamento da Anatel, tabelas de atribuição de faixas de radiofrequências eram aprovadas por resolução. No entanto, esse documento exige uma revisão anual e é, em verdade, uma compilação de informações. Desta forma, as tabelas de atribuição de faixas passaram a ser aprovadas por meio de atos do Presidente do Conselho Diretor da Anatel, por meio de um processo mais célere, que não envolve consulta pública. Apesar disso, tais resoluções fizeram parte da base de dados analisadas.

Houve casos também em que resoluções determinaram a não expedição de novas autorizações para faixas de radiofrequências específicas. Tal procedimento, apesar de ter como objetivo uma determinação para a própria Anatel, instrumento posteriormente alterado para portaria, tais resoluções também fizeram parte da base de dados. Importante mencionar, que nesse caso, não há consulta pública vinculada, uma das razões pelas quais o número de resoluções considerado é diferente do número de consultas públicas. 
Cabe mencionar ainda que há outros documentos relevantes relacionados ao espectro de radiofrequências, tais como editais de licitação. Entretanto, tais documentos não compuseram as bases de dados a serem estudadas. Isso se deve ao fato de eles estabelecerem procedimentos para a escolha das entidades que receberão a outorga para determinadas faixas. Assim, não estão relacionados à destinação e outros aspectos afetos à padronização.

\subsubsection{Consultas públicas}

Como as consultas públicas são exigidas pela LGT para a aprovação de atos normativos, elas são outra importante fonte de dados empíricos. Como, neste caso, foram consideradas somente resoluções referentes à destinação faixas de radiofrequência ou aprovação de regulamentos com alguma padronização, todas as consultas públicas presentes na base de dados foram aprovadas pelo Conselho Diretor da Anatel.

A melhor compreensão do processo de consulta pública é vital para a compreensão do funcionamento da agência reguladora. É o momento em que todos os agentes são chamados a contribuir, eliminando qualquer possível vantagem de um agente sobre outro (HARRIS e MILKIS, 1989). É um mecanismo formal bastante democrático e direto, pois permite a participação de qualquer interessado. Outra leitura das consultas públicas é que elas podem servir de "alarmes de incêndio", possibilitando a mobilização de grupos de interesse (CROLEY, 2000; MCCUBBINS e SCHWARTZ, 1984).

Apesar de possibilitar essa participação, várias perguntas de caráter prático e empírico surgem, mas poucas têm sido estudadas, dentre elas (YACKEE e YACKEE, 2006): A participação, de fato, acontece? Quão democratizante é o mecanismo de consulta pública? Há algum tipo de viés ou domínio por algum grupo? Há outras barreiras, como a de conhecimento, que podem limitar a participação de algum agente? A consulta pública é um meio para se diminuir a assimetria de informação do regulador em relação ao mercado? $O$ presente trabalho pretende contribuir para responder essas perguntas para o caso estudado. 


\subsubsection{Contribuições}

As contribuições são as grandes fontes de informação utilizadas neste estudo para se compreender as influências na regulamentação da Anatel. Isso porque elas fornecem informações sobre o contribuidor, bem como são a tradução da intenção do agente contribuidor. No caso da Anatel, as contribuições devem ainda ser justificadas, o que deixa ainda mais clara a possível intenção do contribuidor.

É importante mencionar também as limitações dessa base de dados. No início da Anatel, não havia sistema para recepção das contribuições. Desta forma, foram utilizadas para esse estudo somente as contribuições recebidas por meio do sistema interativo (SACP).

Interessante observar também que mais recentemente a Anatel vêm experimentando novas formas de interação com a sociedade (a ferramenta Diálogo Anatel é uma delas), entretanto, esses novos processos ainda não foram utilizados para a regulamentação de radiofrequência e não chegaram a formar um conjunto de dados relevante para este estudo.

Outro aspecto importante em relação às contribuições é a existência de resposta ou comentário da Anatel a cada contribuição recebida. Esses comentários permitem averiguar quais contribuições tiveram maior receptividade pela Agência e, assim, compreender a que tipo de influência ela é mais permeável.

\subsection{VARIÁVEIS}

Conforme descrito no item anterior, as influências são avaliadas no momento de realização da consulta pública por parte da Anatel. Essa metodologia tem a desvantagem de não conseguir captar influências anteriores à construção da versão que foi disponibilizada para contribuições.

Essa limitação é reconhecida no presente estudo devido à base de dados utilizada. Antes da realização da consulta pública, o processo é interno da Agência, sendo o momento de consulta pública a primeira oportunidade de interação obrigatória por lei. Desta forma, apesar de em muitas ocasiões os documentos de exposição de motivos das consultas públicas conterem indícios de alguma influência, essas informações são heterogêneas e não servem à construção de uma base de dados confiável. Assim, as variáveis a serem 
utilizadas no presente estudo são aquelas que podem ser extraídas do processo de consulta pública.

A variável dependente, neste caso, é a aceitação ou rejeição pela Anatel de alguma contribuição. Entretanto, nem sempre a aceitação ou não de uma contribuição reflete a aderência de seu conteúdo ao pensamento da Agência. Isso porque as contribuições são sobre o texto regulamentar e mesmo que o conteúdo da contribuição esteja aderente ao pensamento da Agência, ela pode estar mal redigida ou ser imprópria para aquele artigo específico do regulamento. Por esta razão, optou-se por ter como variável dependente se a contribuição teve um comentário positivo, negativo ou neutro.

Para essa classificação, fez-se uma análise de conteúdo da contribuição. Em muitas situações, havia partes da contribuição em que havia um comentário positivo e outro negativo, o que forçou a criação da categoria "neutro".

Como variáveis independentes, utilizou-se a presença ou não de menção à UIT na contribuição ou no comentário da Anatel à contribuição. Ademais, foram utilizadas variáveis de controle, como o tipo de contribuidor (fabricante de equipamentos, prestadora de serviços de telecomunicações, pessoa física, órgãos de governo, associações civis). 


\section{ANÁLISE DA INFLUÊNCIA INTERNACIONAL SOBRE A REGULAÇÃO DE RADIOCOMUNICAÇÕES}

\subsection{ANÁLISE DESCRITIVA}

\subsubsection{Resoluções}

Analisando-se os textos regulamentares, de maneira geral, percebe-se que, conforme previsão legal, houve consulta pública antes da edição das resoluções. Houve apenas uma ocasião em não há menção à realização de consulta pública, a Resolução ํำ79/1998.

Essa resolução refere-se à aprovação de nova tabela de atribuição de frequências, a qual incorporava modificações aprovadas na WRC-97. Era apenas uma formalidade que, provavelmente, à época, não foi considerada uma alteração regulamentar, uma vez que a UIT já havia publicado nova versão do RR com as notas aplicáveis às diversas faixas de frequências. Vale mencionar que, posteriormente, a aprovação de planos e tabelas de atribuição passou a ser expedida pelas Superintendências, não tendo mais caráter de regulamentação aprovada por resolução do Conselho Diretor.

Entre os anos de 1998 e 2014, foram identificadas 99 resoluções aprovadas referentes a regulamentação de radiofrequências. Dessa base de informação, percebe-se uma variação bastante grande no número de resoluções aprovadas por ano, conforme demonstra o gráfico abaixo:

Figura 11: Número de resoluções aprovadas pela Anatel relativas a radiofrequência.

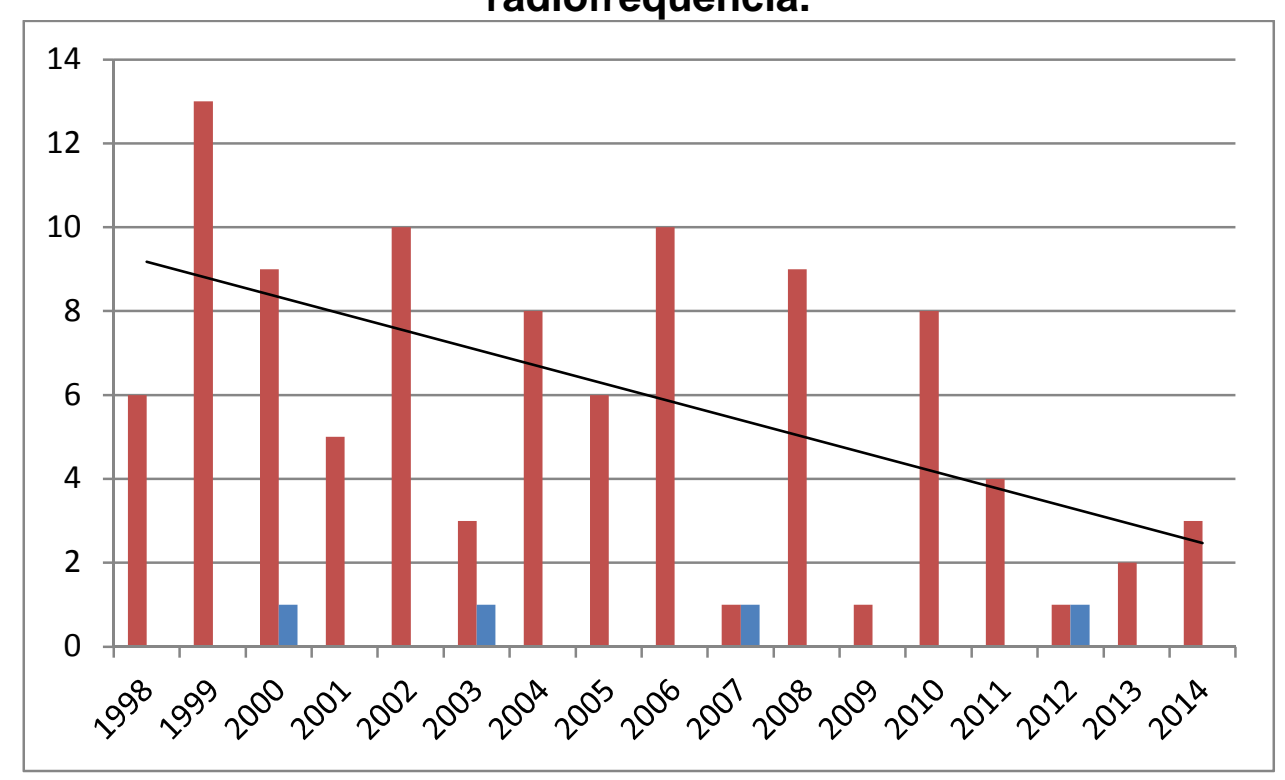

Fonte: elaborado pelo autor. 
A linha central mostra uma tendência à diminuição do número de resoluções aprovadas pela Anatel sobre o assunto. Esse fenômeno pode ter algumas explicações. A primeira é que, no início da Anatel, houve a aprovação de resoluções que substituíram antigos regulamentos do Ministério das Comunicações e que ficaram com seu andamento prejudicado devido à grande mudança institucional ocorrida no final dos anos 1990. Outra explicação é que os regulamentos da Anatel passaram a ser menos específicos, exigindo alterações menos frequentes, além de alterações delegações de competências, como a competência para aprovação de planos de atribuição, conforme mencionado anteriormente.

Os anos marcados em azul são anos em que aconteceram WRCs. Percebe-se assim, que os anos mais profícuos em termos de aprovação de resoluções relativas ao espectro de radiofrequências ocorreram nos intervalos entre WRCs. Isso pode ser justificado pelo fato de que a área que produz os estudos e a documentação para uma alteração regulamentar é a mesma que trabalha nos fóruns internacionais, razão pela qual seria operacionalmente mais complicado produzir nesse período.

Outra razão plausível é que a WRC pode servir como forma de agendamento. Após ter uma faixa atribuída para determinado serviço na WRC, - Brasil e os demais países podem editar regulamentação sobre o uso daquela determinada faixa. Assim, um número de assuntos pode surgir após a WRC, os quais trarão reflexo (aprovação de regulamentação) após algum tempo, no intervalo entre as Conferências.

A análise causal de tal hipótese exigiria a averiguação de todos os processos de regulamentação, abrindo-se o tema e verificando se ele foi tratado em uma WRC anterior. Tal análise foge do que se pretende para o presente estudo e também poderia trazer resultados equivocados, uma vez que outras publicações realizadas pela UIT fora de WRCs (relatórios, por exemplo), poderiam igualmente impactar na agenda da entidade reguladora e caracterizar uma influência da UIT. Ademais, a informação de data de abertura de processo não está disponível para procedimentos iniciados pela Anatel antes de 2006, o que inviabilizaria a pesquisa. Apenas a título ilustrativo, está resumido no 
gráfico abaixo os dados disponíveis quando a abertura de processo de regulamentação de espectro e a realização de WRCs:

Figura 12 - Abertura de processos de regulamentação pela Anatel e realização de WRCs.

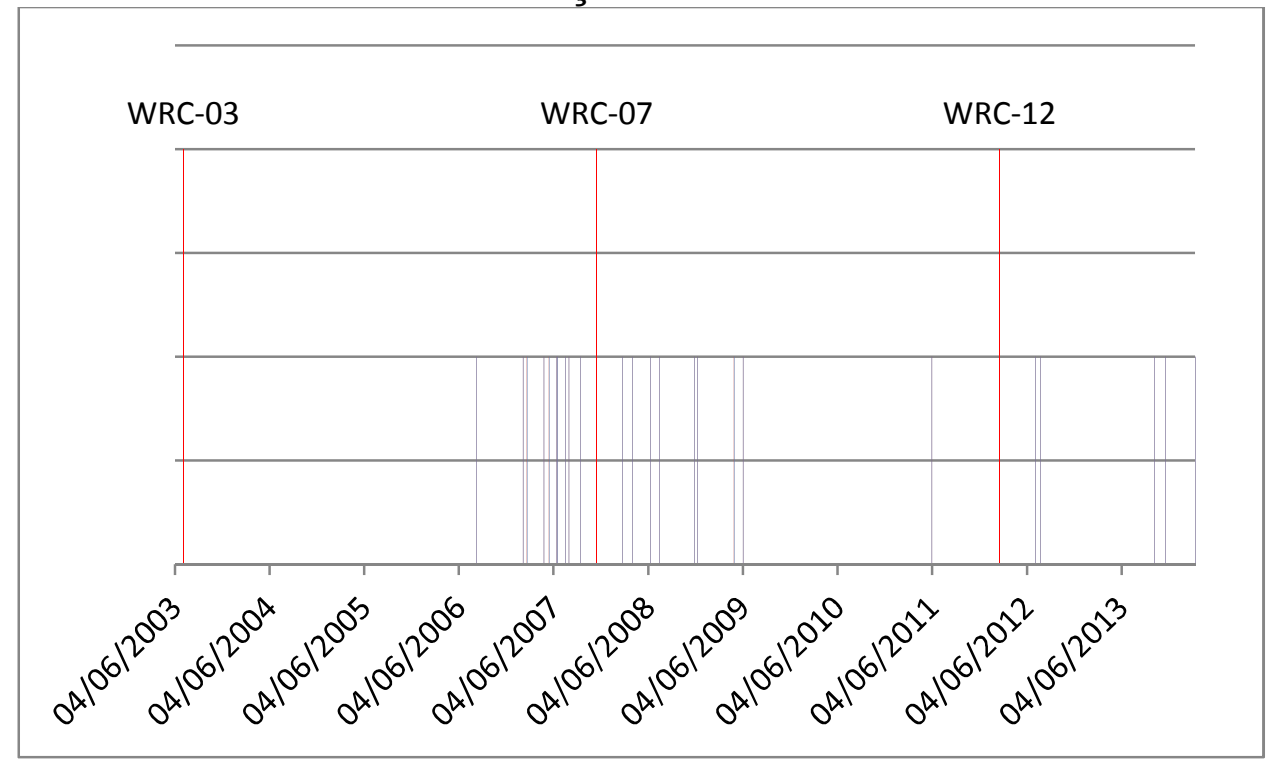

Fonte: elaborado pelo autor.

\subsubsection{Consultas públicas}

Por exigência legal, todos os atos normativos da agência devem ser precedidos de consultas públicas, o que fornece uma interessante base de dados para se analisar as influências que incidem sobre essa autarquia. É bem verdade que certas influências podem acontecer de outras formas, o que exigiria métodos específicos para se identificar essas situações. No entanto, como caso geral, as consultas públicas são um elemento importante a ser investigado.

Dessas 98 resoluções em que houve consulta pública, apenas 80 estão na base do Sistema de Acompanhamento de Consultas Públicas (SACP) da Anatel. Isso porque, no início da Agência, esse sistema ainda não havia sido desenvolvido e as contribuições eram recebidas de maneira menos estruturada, o que dificulta a mineração e o uso desses dados. Desta forma, para análise que será realizada, foram consideradas somente as 80 consultas públicas disponíveis no SACP. 
As consultas públicas estão distribuídas temporalmente da seguinte forma ${ }^{41}$ :

Figura 13 - Número de consultas públicas sobre radiocomunicações por ano.

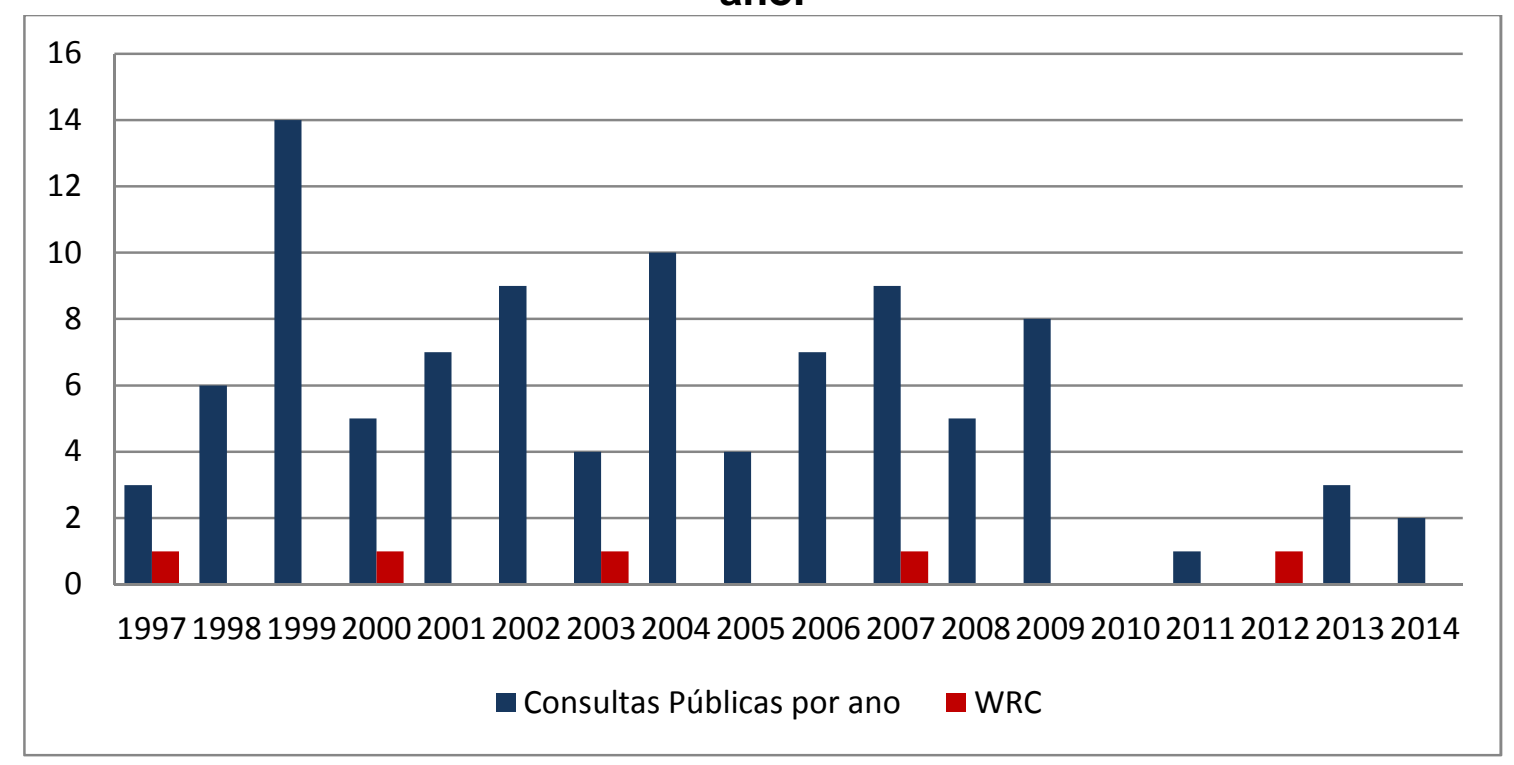

Fonte: elaborado pelo autor.

Como era de se esperar, o número de consultas públicas diminui ao longo do tempo, da mesma forma que o número de resoluções. São observadas também algumas sazonalidades.

Essas sazonalidades diferem-se um pouco das observadas nas resoluções, uma vez que nem todos os processos tem o mesmo período de duração entre a realização da consulta pública e a aprovação da versão final do regulamento.

Quanto ao prazo para contribuições, observa-se o seguinte:

\footnotetext{
${ }^{41}$ Neste gráfico estão inseridas todas as 97 consultas públicas, mas as análises seguintes somente consideram as 80 disponíveis no SACP (Sistema de Acompanhamento de Consultas Públicas).
} 
Figura 14 - Distribuição da duração (em dias) das consultas públicas sobre radiofrequência.

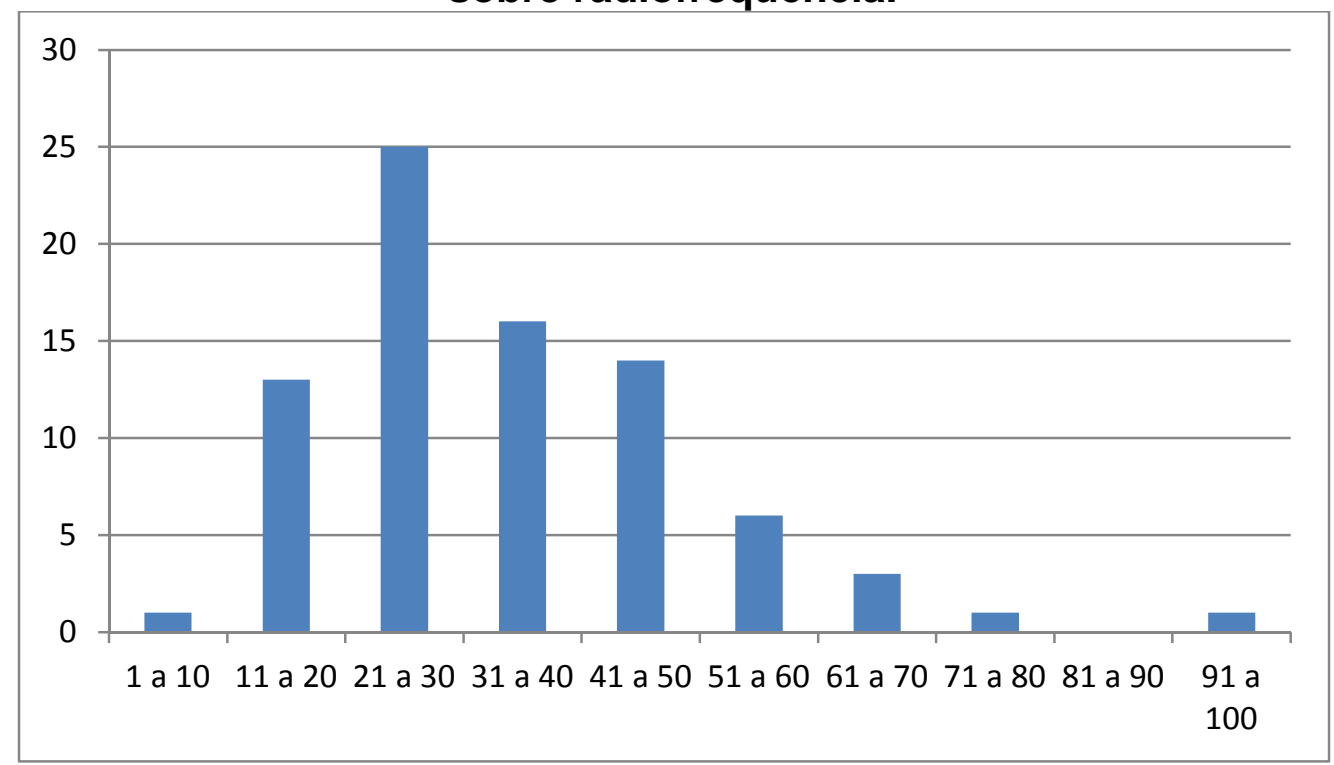

Fonte: elaborado pelo autor.

O prazo para contribuições pode refletir duas questões, a primeira é a urgência em se aprovar uma regulamentação e a segunda é o grau de complexidade da proposta.

\subsubsection{Contribuições}

Quanto ao número de contribuições recebidas, também há uma grande variação, conforme demonstra o gráfico a seguir:

Figura 15 - Número de contribuições por consulta pública.

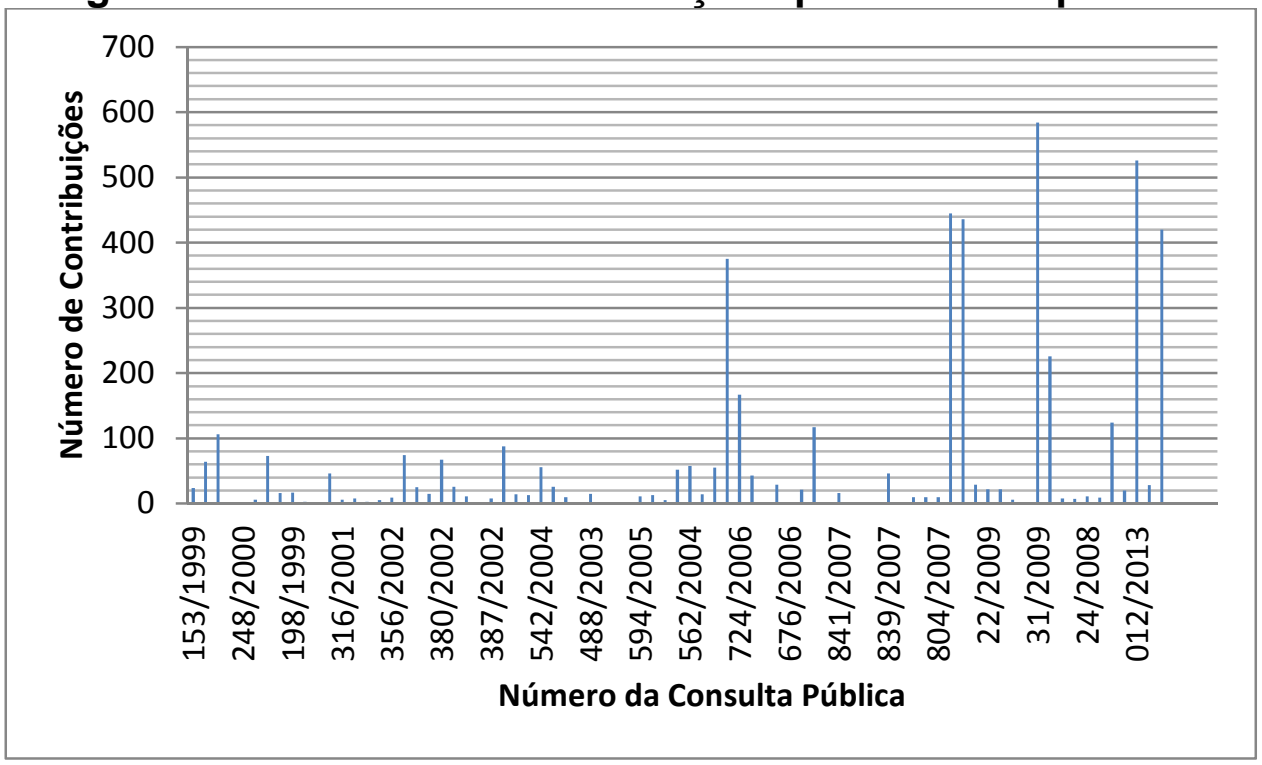

Fonte: elaborado pelo autor.

Como forma de prestação de contas (accountability), as contribuições às consultas públicas precisam ser respondidas. Essa resposta pode se dar de 
duas formas. A primeira forma, mais direta e mais assertiva, é responder individualmente cada contribuição por meio de comentários, os quais ficam disponíveis no SACP. A segunda maneira é por meio de um documento final em que são expostas as razões para aceitação ou não das contribuições. Esse segundo modo é menos assertivo, mas promove também as justificativas para as conclusões finais da Agência.

Entretanto, no segundo modo de resposta, é difícil saber exatamente qual contribuição foi aceita ou não e qual a sua influência no texto final. Para se realizar essa avaliação, para cada consulta pública, deveria ser feita uma análise do mérito da questão, para saber se a contribuição foi ou não aceita e em que extensão. No primeiro modo, isso é muito mais claro pelos comentários individualizados fornecidos pela agência.

Para minimizar esses problemas metodológicos, preferiu-se concentrar atenção nas consultas públicas que foram efetivamente respondidas por meio do sistema, o que exige uma caracterização específica dessas consultas.

Antes, no entanto, faz-se uma comparação entre contribuições com respostas e sem respostas para saber se há alguma característica específica em cada um desses tipos.

A primeira questão a se observar é a sua distribuição temporal:

Figura 16 - Distribuição temporal da existência de resposta às contribuições.

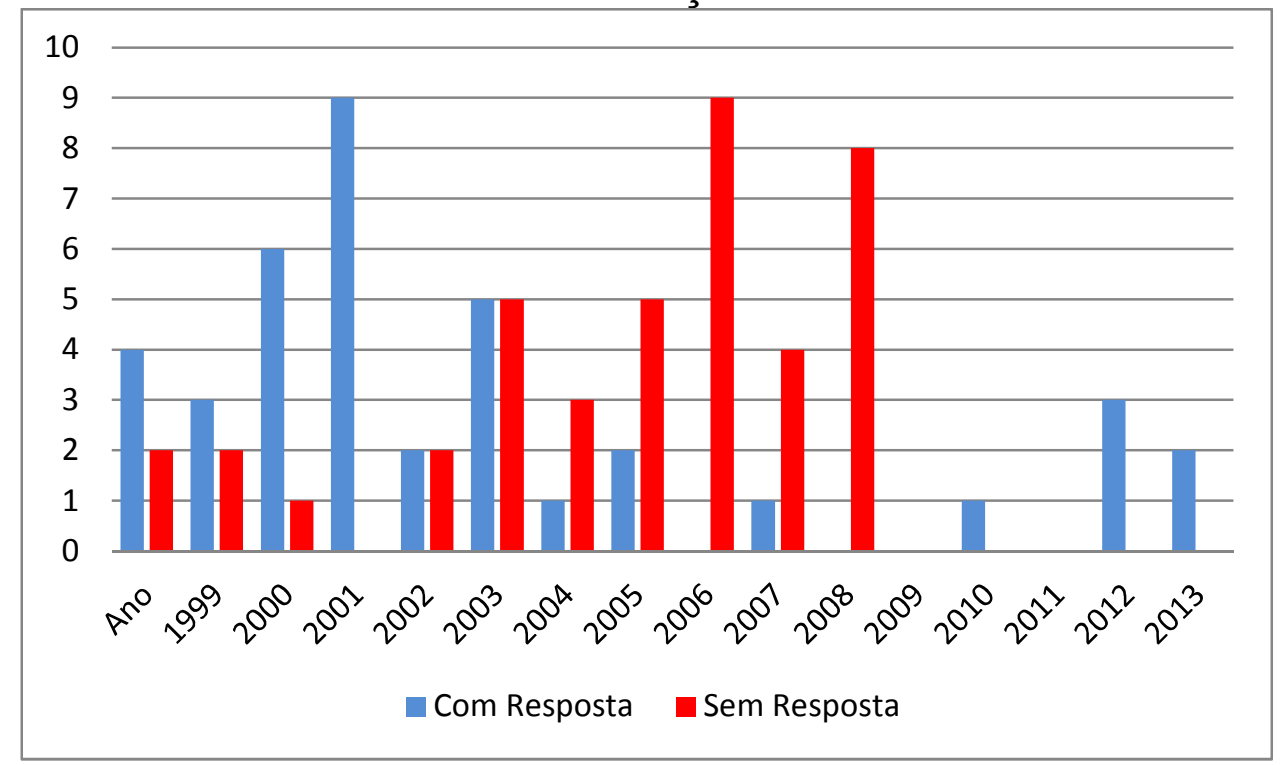

Fonte: elaborado pelo autor. 
Percebe-se que as consultas públicas sem comentários às contribuições concentraram-se entre os anos de 2003 e 2008.

Quanto ao número de contribuições e a duração médias das consultas públicas, o quadro comparativo abaixo resume a situação:

Tabela 14 - Comparação entre as consultas públicas com e sem resposta.

\begin{tabular}{|c|c|c|}
\hline & $\begin{array}{c}\text { Contribuições com } \\
\text { comentários da Anatel }\end{array}$ & $\begin{array}{c}\text { Contribuições sem } \\
\text { comentários da Anatel }\end{array}$ \\
\hline $\begin{array}{c}\text { Número de Consultas } \\
\text { Públicas }\end{array}$ & 39 & 41 \\
\hline $\begin{array}{c}\text { Número de } \\
\text { Contribuições }\end{array}$ & 1975 & 2851 \\
\hline Média de contribuições & 50,64 & 69,54 \\
\hline Duração média & 32 & 35 \\
\hline
\end{tabular}

Fonte: elaborado pelo autor.

Percebe-se que consultas públicas sem comentários da Anatel têm uma duração média e um número significativamente maior de contribuições. Isso pode indicar uma maior complexidade das consultas públicas nas quais as contribuições não foram individualmente comentadas. Entretanto, mesmo no conjunto de contribuições com comentários, percebe-se um conjunto de consultas públicas longas e com muitas contribuições, o que possibilitaria a análise desse tipo perfil de consulta pública, conforme descrito abaixo.

Quanto ao número de contribuições respondidas, elas têm o seguinte perfil:

Figura 17 - Número de contribuições com comentários por consulta pública.

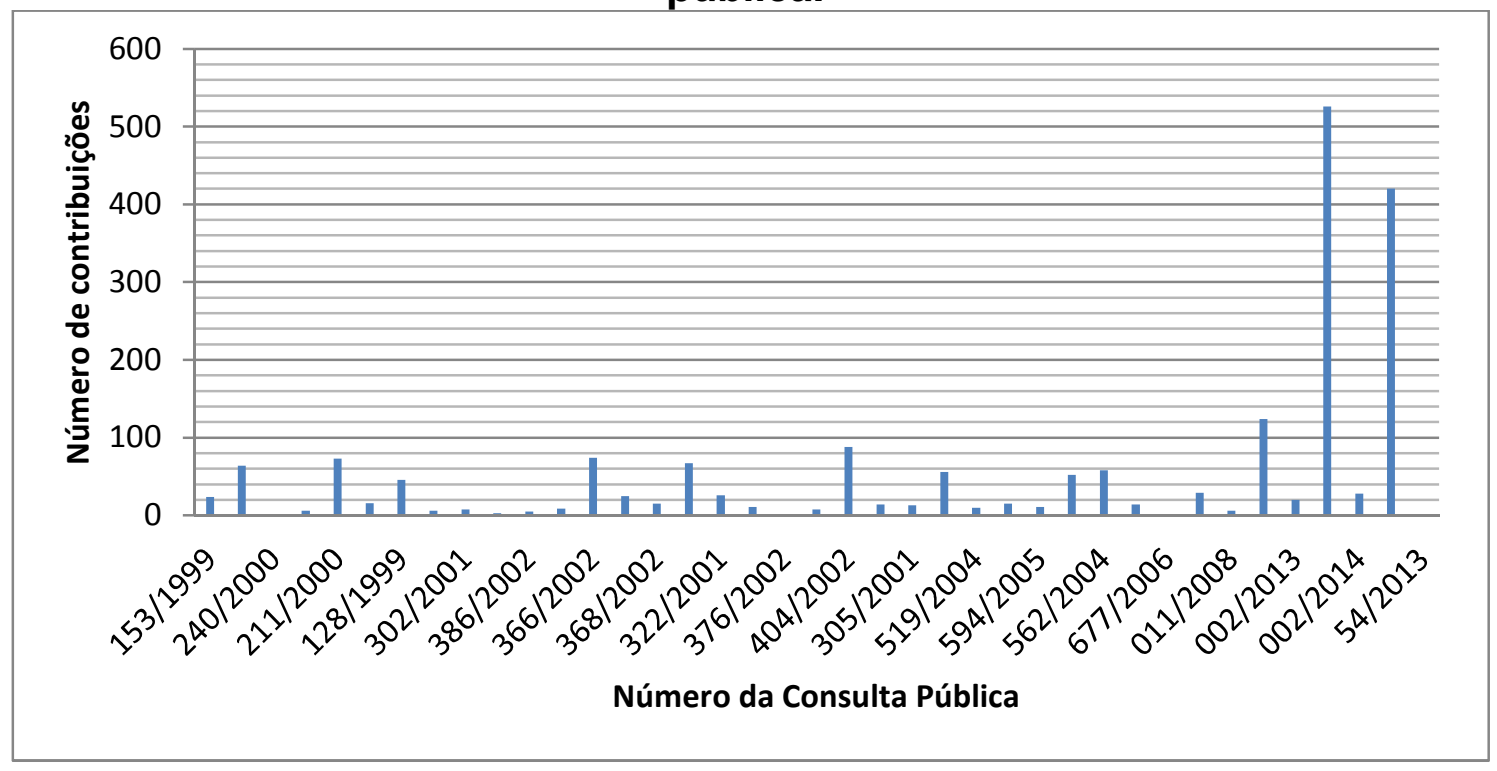

Fonte: elaborado pelo autor.

\footnotetext{
${ }^{42}$ Dessas, 6 consultas públicas não foram respondidas por não terem recebido contribuições.
} 
Como se pode perceber, duas consultas públicas recentes se destacam em número de contribuições. Essas consultas são as de número 12/2013 e 18/2014, que tiveram, respectivamente, 526 e 420 contribuições. Com um total de 1975 contribuições para 32 consultas públicas, somente essas duas consultas tiveram cerca de $48 \%$ das contribuições. Por esta razão e para evitar um possível viés na análise, elas são tratadas de maneira individualizada.

\subsubsection{Contribuidores}

Para que se possa fazer uma análise sobre a possível influência de algum contribuidor, é necessário antes classificá-los. Neste trabalho, adota-se a seguinte classificação ${ }^{43}$ :

- $\quad$ Associação Civil;

- $\quad$ Escritório de Advocacia;

- $\quad$ Fabricante de soluções;

- $\quad$ Pessoa Física;

- Prestadora de Serviços de Telecomunicações;

- Radiodifusor.

Vale salientar que os contribuidores podem ou não se identificar como parte de alguma organização. Aquelas pessoas não que não se identificaram como pertencentes a alguma organização foram consideradas como contribuições de pessoas físicas, mesmo que seja sabido que tal pessoa faz parte de alguma organização. Escolheu-se essa abordagem pois se entende que a pessoa, ao não se identificar como pertencente a alguma organização, fala em nome próprio e não em nome de alguma organização.

Como associação civil, foram entendidas as entidades relacionadas a proteção dos direitos dos consumidores ou defensoras de interesses difusos, como o Idec (Instituto Brasileiro de Defesa do Consumidor) e o Instituto Bem Estar Brasil.

A categoria de escritório de advocacia foi criada para abarcar contribuidores que assim se identificaram, impossibilitando a classificação em alguma outra categoria. É bem provável que o escritório de advocacia estivesse relacionado a posicionamento de alguma das outras categorias, no

\footnotetext{
${ }^{43}$ Classificação realizada somente nas consultas públicas em que há comentários individualizados da Anatel.
} 
entanto, não se pode assumir isso a priori, já que o contribuidor não fez esse reconhecimento.

A categoria de Prestadora de Serviço de Telecomunicações é uma categoria bastante heterogênea. Ela abriga desde prestadoras de diversos portes, bem como de diversos serviços. Entretanto, para a finalidade deste trabalho, não foi necessária a criação de subcategorias, pois todas as prestadoras têm objetivos similares quanto à governança.

A categoria de Radiodifusor poderia também ser entendida como uma "Prestadora de Telecomunicações" lato sensu. No entanto, devido a peculiaridades das Consultas Públicas n 12/2013 e n¹8/2014, que tiveram que ser tratadas especificamente, essa subdivisão se fez necessária.

Interessante observar também que não houve nenhuma contribuição de consultoria, um tipo de agente importante na difusão do arranjo institucional das agências reguladoras (AMARAL, 2000). Entretanto, elas são agentes que não devem ser descartados, pois podem ainda ser contratados por qualquer um dos outros agentes e realizar, da mesma forma, a circulação de ideias identificadas necessárias ao policy transfer. Apesar disso, observa-se desde já que tais agentes não foram utilizados como legitimadores ou "emblemas" de qualidade, como em outros momentos.

Ademais, vale mencionar que nenhuma contribuição foi identificada como proveniente de universidade, por isso essa possível categoria não aparece na classificação. Essa questão chamou a atenção e será explorada no decorrer deste trabalho.

Quanto à distribuição das contribuições entre esses atores, ela seguiu a distribuição abaixo: 
Figura 18 - Distribuição das contribuições segundo contribuidor.

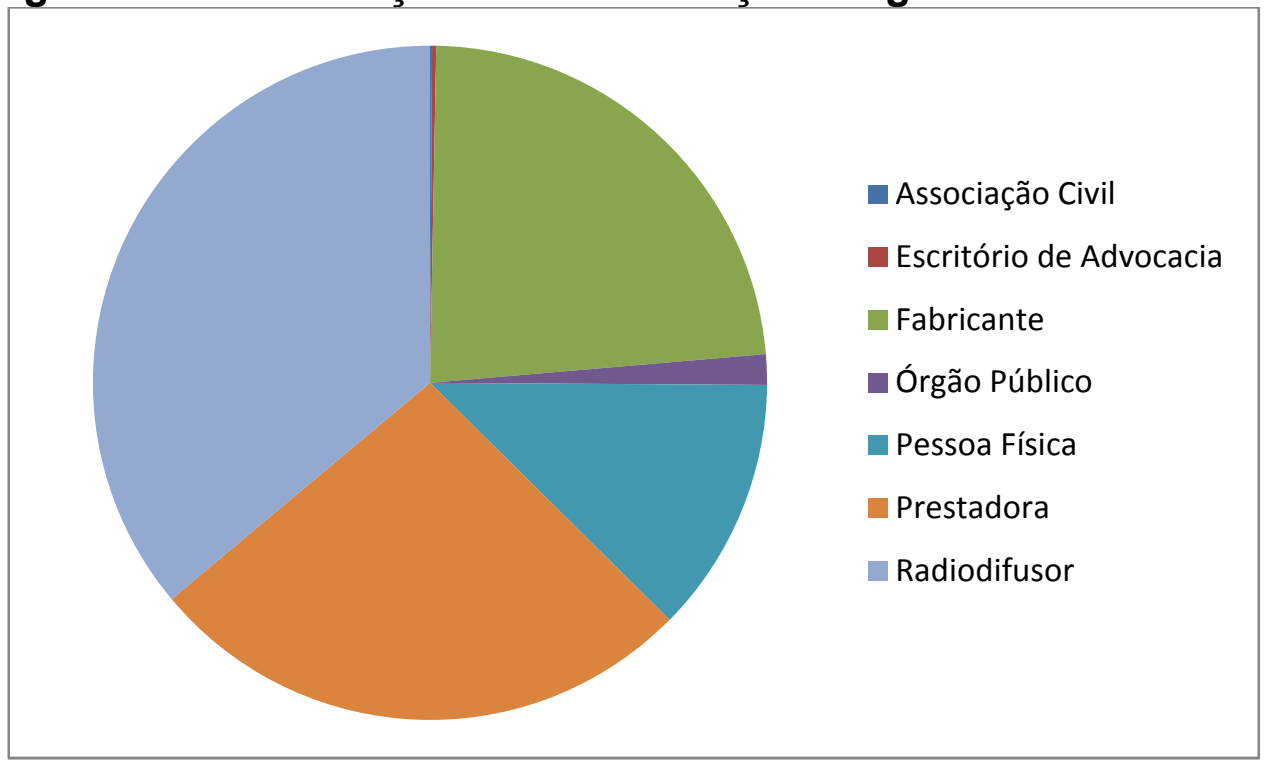

Fonte: elaborado pelo autor.

Analisando-se separadamente as contribuições e segregando os dados das Consultas Públicas n 12/2013 e 18/2014, tem-se o seguinte resultado:

\section{Figura 19 - Distribuição das contribuições segundo contribuidor} (detalhe).

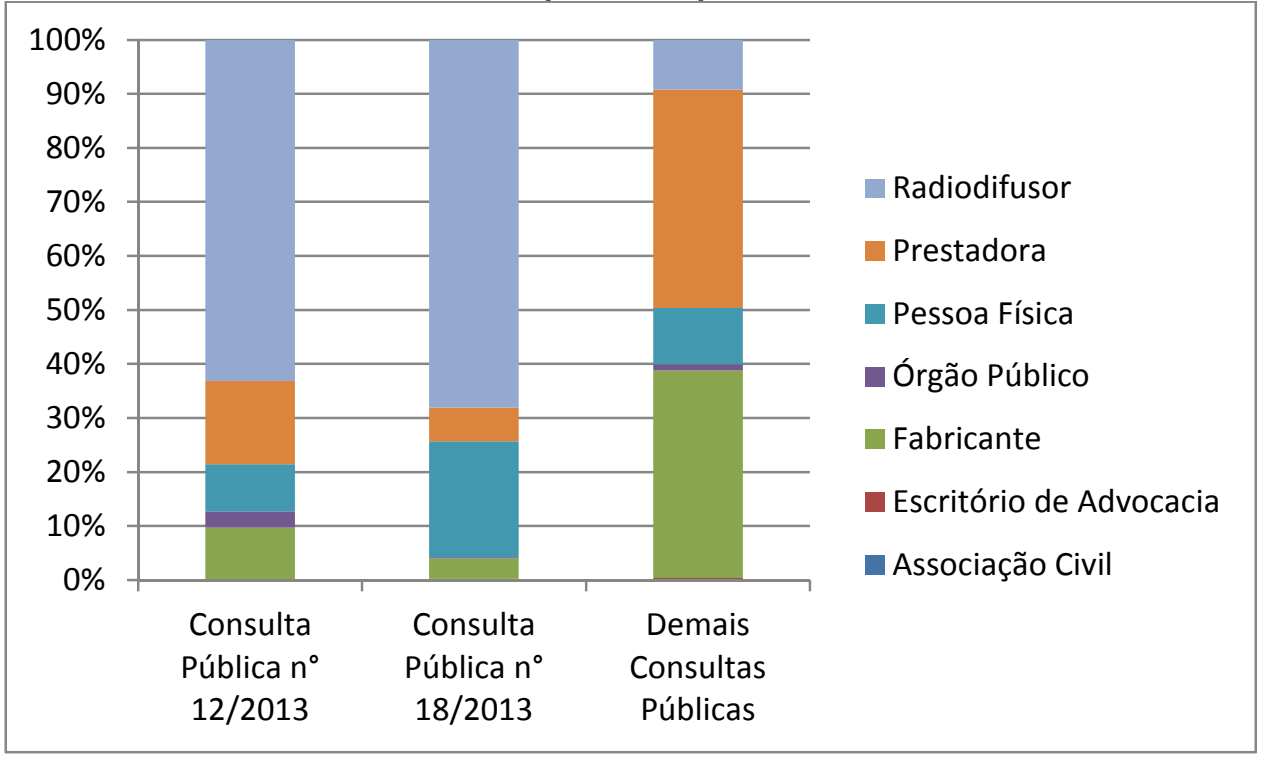

Fonte: elaborado pelo autor.

Como já se esperava, os radiodifusores demonstraram um grande interesse pelas Consultas Públicas n 12/2013 e n 18/2014, uma vez que a proposta era destinar parte da faixa utilizada por canais de TV para outros serviços, incluindo banda larga móvel (SMP - Serviço Móvel Pessoal). 


\subsection{DISCUSSÃO DOS RESULTADOS}

Conforme descrito no item 3.5, os comentários às contribuições foram classificados como positivos, negativos ou neutros. Com essa classificação feita em todas as contribuições comentadas, obtém-se o seguinte resultado geral:

Figura 20 - Posição da Anatel sobre as contribuições recebidas.

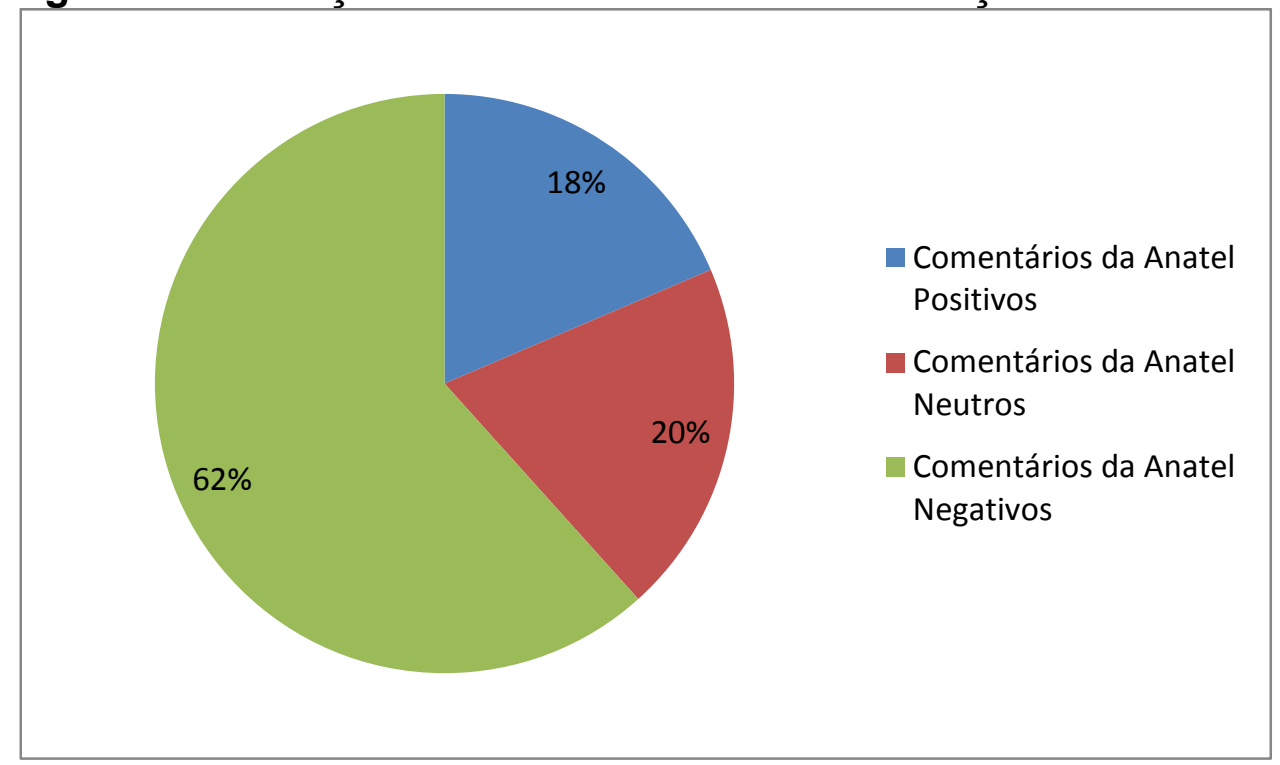

Fonte: elaborado pelo autor.

Quando se separa as Consultas Públicas n 12/2013 e n 18/2014, têmse o seguinte resultado:

Figura 21 - Posição da Anatel sobre as contribuições recebidas (detalhe).

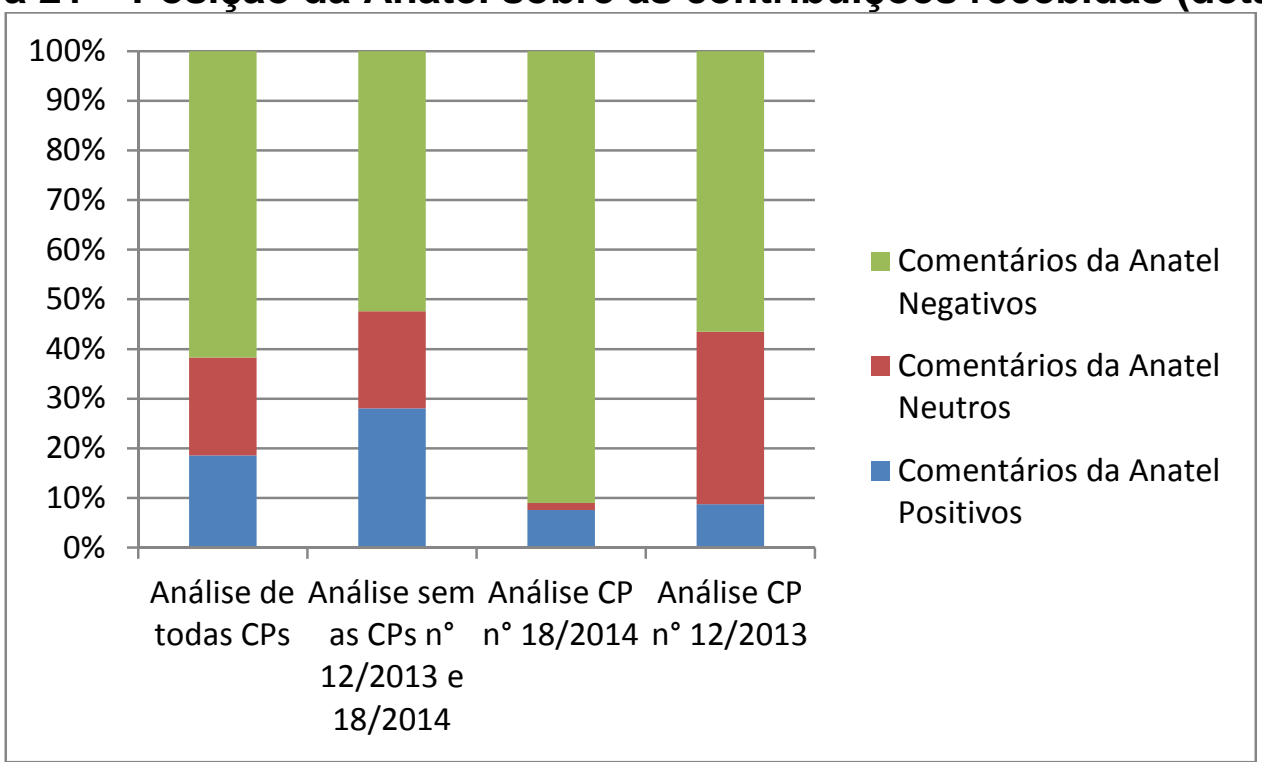

Fonte: elaborado pelo autor.

Como se percebe claramente, o número de comentários negativos por parte da agência é a maioria. Isso significa que é difícil alterar um 
posicionamento inicialmente formado pela Anatel. No entanto, reflete também que a Anatel pondera sobre as contribuições recebidas a ponto de responder 0 porquê rejeitou alguma contribuição. Destaca-se também uma grande rejeição de contribuições recebidas na Consulta Pública n 18/2014. Tal fato será mais bem elucidado mais adiante.

Como o objetivo deste estudo é verificar influências da governança global, procurou-se também verificar quais contribuições mencionaram a UIT e o resultado foi o seguinte:

Figura 22 - Contribuições ou comentários da Anatel que mencionam a UIT.

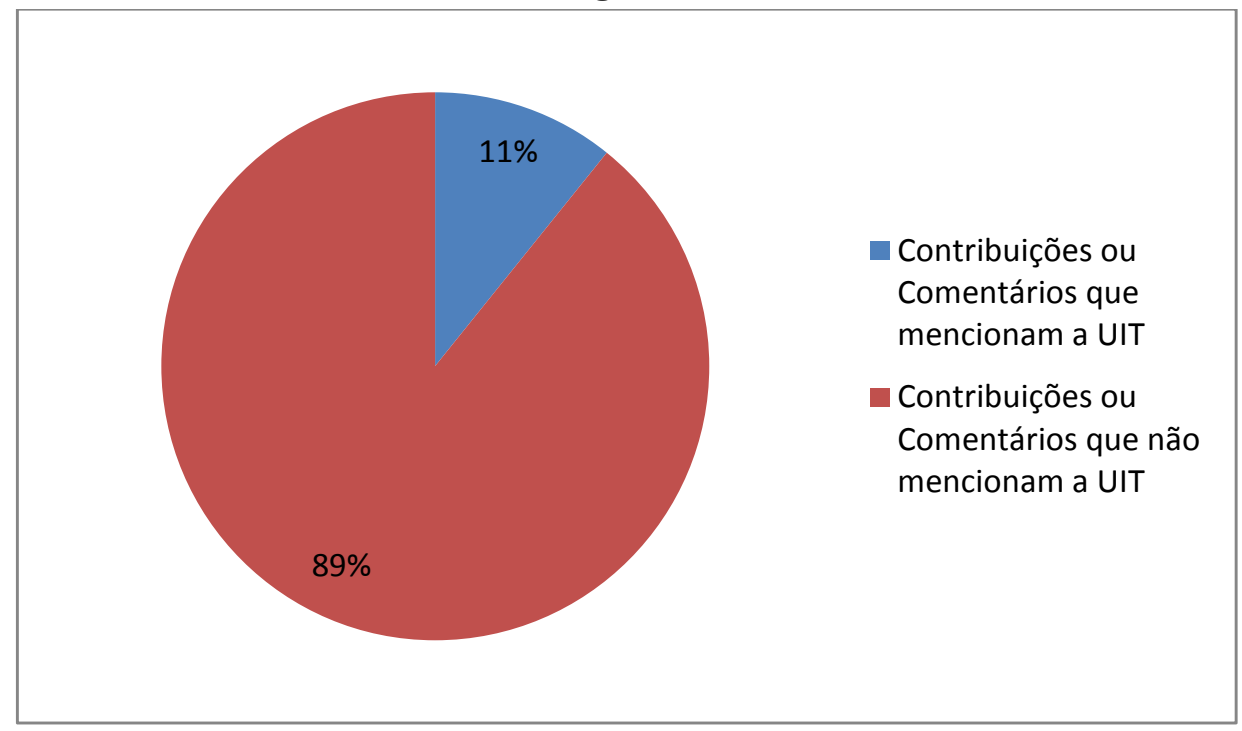

Fonte: elaborado pelo autor.

Analisando-se separadamente as Consultas Públicas $n^{\circ} 12 / 2013$ e $n^{\circ}$ 18/2014, as contribuições e comentários que envolvem a UIT tem a seguinte distribuição: 
Figura 23 - Contribuições ou comentários da Anatel que mencionam a UIT (detalhe).

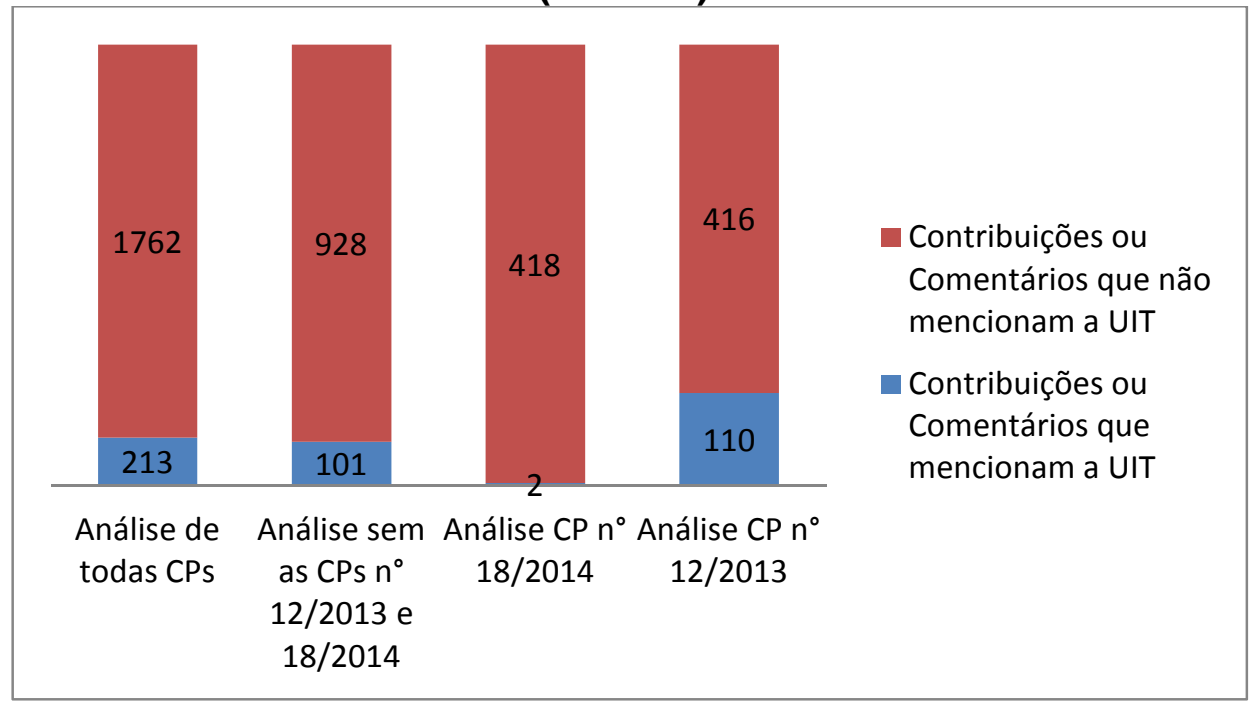

Fonte: elaborado pelo autor.

O percentual de contribuições ou comentários que mencionam a UIT não é proporcionalmente muito grande. Isso se deve ao fato de que as resoluções tratam de muitos aspectos, como prazos e questões que se referem a particularidades nacionais, o que não é abordado em documentos internacionais. Por essa razão, tais aspectos não podem ser justificados ou embasados em normativas internacionais.

Há que se verificar agora, se as contribuições ou comentários que mencionam a UIT têm uma maior aceitação por parte da Anatel. A tabela abaixo resume a aceitação dessas contribuições e das demais:

Tabela 15 - Aceitação das contribuições quando elas mencionam ou não a UIT.

\begin{tabular}{|l|c|c|c|c|}
\hline & $\begin{array}{c}\text { Análise de } \\
\text { todas CPs }\end{array}$ & $\begin{array}{c}\text { Análise sem as } \\
\text { CPs n 12/2013 } \\
\text { e 18/2014 }\end{array}$ & $\begin{array}{c}\text { Análise } \\
\text { CP n } \\
\mathbf{1 8 / 2 0 1 4}\end{array}$ & $\begin{array}{c}\text { Análise } \\
\mathrm{CP}^{\circ} \\
\mathbf{1 2 / 2 0 1 3}\end{array}$ \\
\hline $\begin{array}{l}\text { Comentários da Anatel } \\
\text { Positivos }\end{array}$ & 367 & 289 & 32 & 46 \\
\hline $\begin{array}{l}\text { Comentários da Anatel } \\
\text { Neutros }\end{array}$ & 390 & 201 & 6 & 183 \\
\hline $\begin{array}{l}\text { Comentários da Anatel } \\
\text { Negativos }\end{array}$ & 1218 & 539 & 382 & 297 \\
\hline
\end{tabular}




\begin{tabular}{|l|c|c|c|c|}
\hline & $\begin{array}{c}\text { Análise de } \\
\text { todas CPs }\end{array}$ & $\begin{array}{c}\text { Análise sem as } \\
\text { CPs n 12/2013 } \\
\text { e 18/2014 }\end{array}$ & $\begin{array}{c}\text { Análise } \\
\text { CP n } \\
18 / 2014\end{array}$ & $\begin{array}{c}\text { Análise } \\
\text { CP n } \\
\mathbf{1 2 / 2 0 1 3}\end{array}$ \\
\hline $\begin{array}{l}\text { Contribuições ou } \\
\text { Comentários que } \\
\text { mencionam a UIT }\end{array}$ & 213 & 101 & 2 & 110 \\
\hline $\begin{array}{l}\text { Contribuições ou } \\
\text { Comentários que não } \\
\text { mencionam a UIT }\end{array}$ & 1762 & 928 & 418 & 416 \\
\hline $\begin{array}{l}\text { Porcentagem de } \\
\text { Comentários Positivos } \\
\text { quando a contribuição } \\
\text { menciona UIT }\end{array}$ & $17 \%$ & $37 \%$ & $0 \%$ & $0 \%$ \\
\hline $\begin{array}{l}\text { Porcentagem de } \\
\text { Comentários Positivos } \\
\text { quando a contribuição não } \\
\text { menciona UIT }\end{array}$ & $19 \%$ & $31 \%$ & $8 \%$ & $11 \%$ \\
\hline
\end{tabular}

Observando-se os resultados agregados, imagina-se que as contribuições que mencionam a UIT não têm uma boa aceitação por parte da Agência. No entanto, desagregando-se os resultados para as Consultas Públicas $n^{\circ} 12 / 2013$ e $n^{\circ} 18 / 2014$, percebe-se que as contribuições mencionadas têm uma aceitação maior, conforme a hipótese inicial.

As contribuições que mencionam a UIT não tiveram uma boa aceitação nas Consultas Públicas $n^{\circ}$ 12/2013 e n¹8/2014, mesmo considerando-se que as contribuições a essas consultas tiveram uma aceitação abaixo da média das demais. As contribuições rejeitadas eram, em sua maioria, oriundas de radiodifusores ou de entidades ligadas a radiodifusão. Elas (as contribuições), em geral, faziam menções a recomendações e relatórios da UIT sobre testes, bem como teciam considerações sobre coordenação de frequência com países vizinhos. A Anatel rebateu essas contribuições também argumentando que utilizava parâmetros estabelecidos pela UIT e por outros organismos padronizadores. Apenas a título ilustrativo, cita-se alguns trechos de contribuição e de justificativa.

Trecho de justificativa de contribuição de radiodifusor: 
O Ministério de Assuntos Internos e Comunicação (MIC) do Japão, que possui um sistema de TV Digital semelhante ao brasileiro (ISDBT), assim como a UIT e o 3GPP, utilizam, neste caso, $36 \mathrm{dBm} / \mathrm{MHz}$. Os parâmetros de transmissão precisam ser estabelecidos após os testes de compatibilidade do serviço proposto com o serviço de radiodifusão.

Trecho de comentário da Anatel à referida contribuição:

Contribuição não aceita. Os valores de potência e de emissões indesejáveis serão revistos considerando padrões do $3 G P P$ e da UIT-R.

Percebe-se, assim, que tanto a Anatel, quanto os contribuidores utilizam a UIT e documentos produzidos por outras entidades para justificar seu posicionamento. A referência a UIT e a outras entidades padronizadoras, como o 3GPP, passa ser um legitimador do posicionamento, uma espécie de "selo" de qualidade e de credibilidade.

Passa-se agora a uma análise sobre os contribuidores. O perfil dos contribuidores seguiu a seguinte distribuição:

Figura 24 - Percentual de contribuições de acordo com o contribuidor.

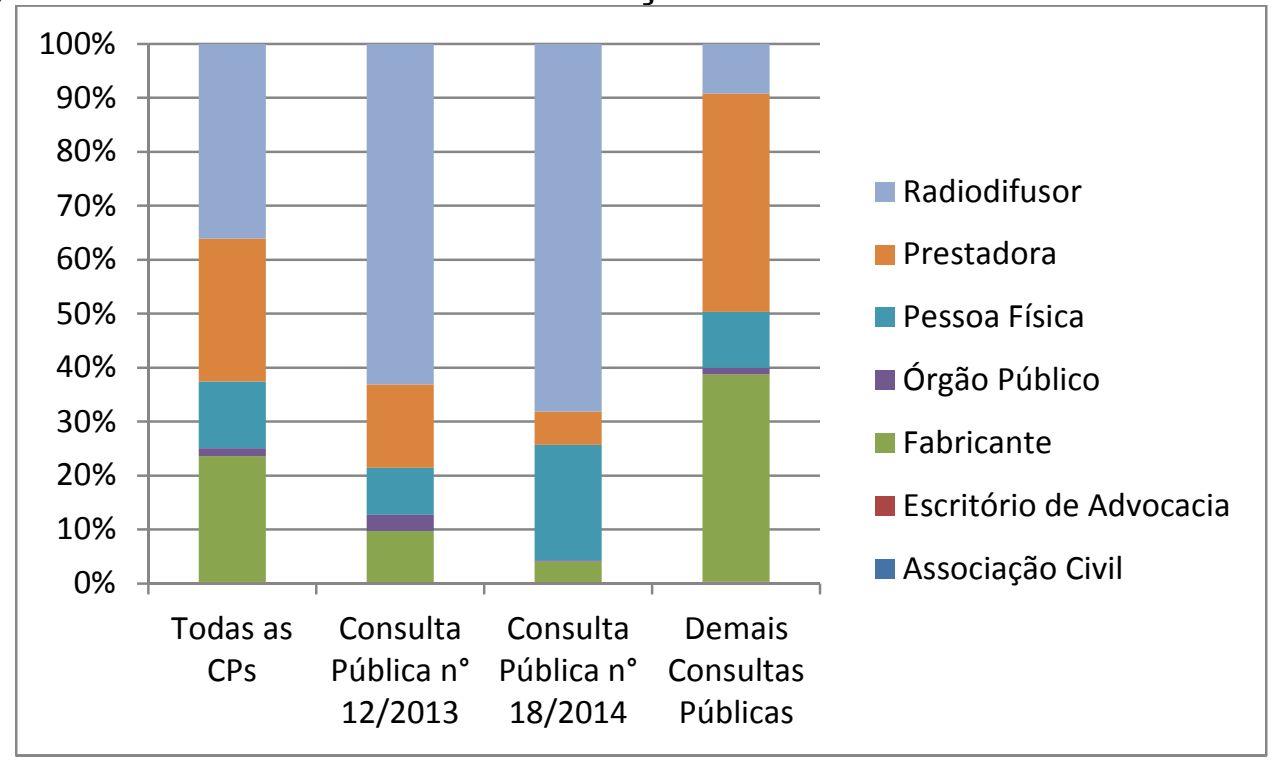

Fonte: elaborado pelo autor.

Quando se observa somente as Consultas Públicas $n^{\circ} 12 / 2013$ e $n^{\circ}$ 18/2014, percebe-se a grande mobilização que essas consultas geraram no setor de radiodifusão, algo percebido com intensidade bem menor em outras 
consultas públicas. Analisando-se as demais consultas públicas, percebe-se dois perfis de contribuidores de destaque, as prestadoras e os fabricantes.

As prestadoras são impactadas diretamente pela regulamentação e estão sempre em defesa de seus interesses, por isso uma participação tão presente. Os fabricantes, por sua vez, não são regulados diretos, mas são também impactados pela regulamentação de radiocomunicações. Eles (fabricantes), na condição de desenvolvedores de soluções e tecnologias, querem que seus equipamentos sejam admitidos pela regulamentação, além de desejarem, eventualmente, que soluções rivais às suas possam, de alguma maneira, serem dificultadas.

Quanto à aceitação das contribuições de acordo com o contribuidor, percebe-se o seguinte:

Figura 25 - Percentual de comentários positivos da Anatel de acordo com o contribuidor.

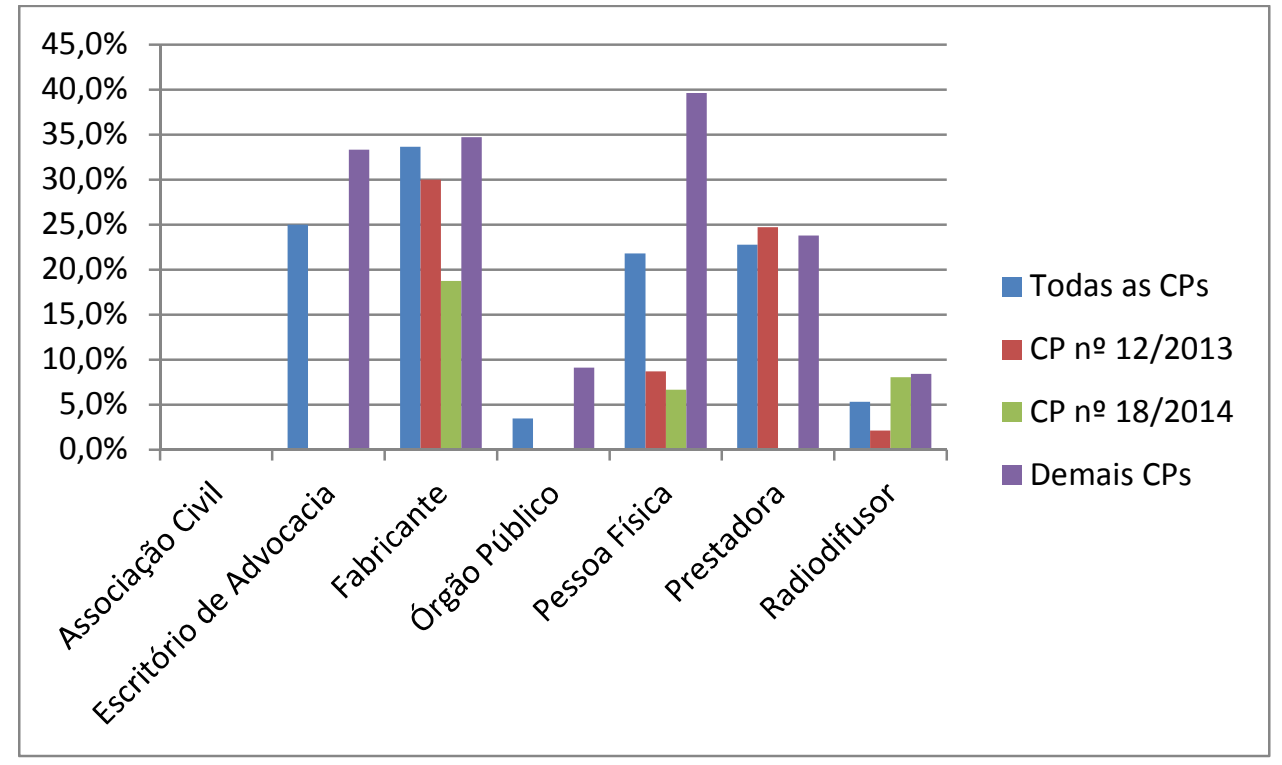

Fonte: elaborado pelo autor.

O valor mais destacado refere-se às contribuições de Pessoa Física, quando se considera todas as consultas públicas, com exceção às CPs $n^{\circ}$ $12 / 2013$ e $n^{\circ} 18 / 2014$. Por serem diversas consultas e não se observar um perfil homogêneo nessa categoria, não se pode apontar uma única razão para essa aceitação maior. Percebe-se também uma aceitação muito baixa de contribuições provenientes de Associações Civis e de Escritórios de Advocacia. Tal fato se deve ao número extremamente baixo de contribuições desse tipo de contribuidor (4 de Escritórios de Advocacia e 2 de Associações Civis). 
Entretanto, essa é uma característica específica da regulamentação do espectro de radiofrequência. Por ser um tema extremamente técnico, escritórios de advocacia ou associações civis normalmente não dão a mesma atenção que é dada a questões como direito dos usuários ou questões mais jurídicas de regulação.

Analisando-se as categorias de contribuidores de maneira agregada, percebe-se uma aceitação maior de contribuições por parte de fabricantes, seguidos por prestadoras e radiodifusores. Tal tendência também se mantem quando se observa de maneira separada as CPs n 12/2013 e n 18/2014.

De modo que não só a aceitação, mas também a rejeição possa ser analisada (comentários negativos), avaliou-se também esse quesito, com 0 seguinte resultado:

Figura 26 - Percentual de comentários negativos da Anatel de acordo com o contribuidor.

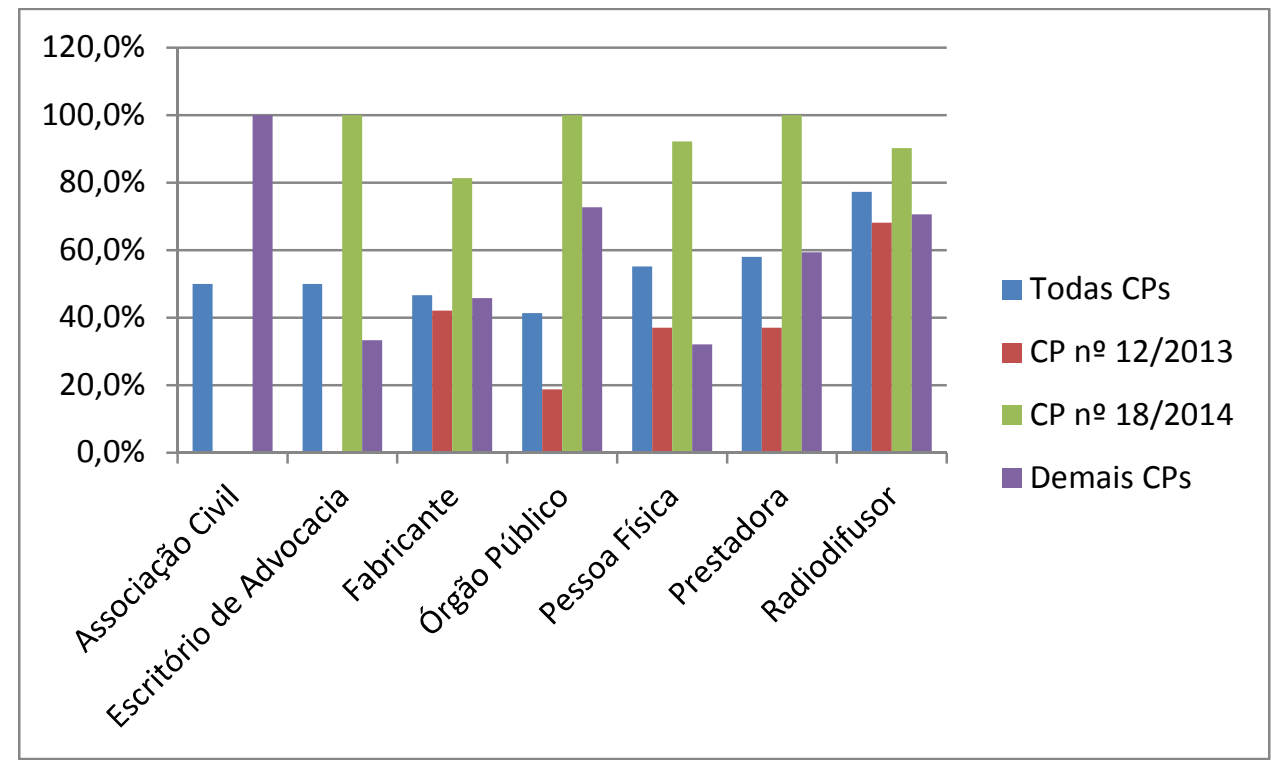

Fonte: elaborado pelo autor.

Analisando-se as categorias de Prestadora, Radiodifusor e Fabricante, percebe-se a mesma tendência dos comentários positivos, com os fabricantes tendo suas contribuições com melhor receptividade por parte da Agência.

Tal fato pode ser justificado pelo fato de que os fabricantes geralmente se referem a aspectos tecnológicos e, como são os eles próprios os desenvolvedores de tecnologia, é mais difícil para que a agência reguladora rejeite essas contribuições (assimetria de conhecimento tecnológico). As prestadoras e radiodifusores contribuem também para outros aspectos da 
regulação, que, devido à sua natureza mais conflitiva (questões redistributivas, por exemplo), têm um padrão de aceitação/rejeição menos regular.

\subsubsection{Desenvolvimento de um modelo de governança para o caso concreto}

Neste estudo, algumas lógicas são invertidas. A primeira dessas lógicas é a de que durante a criação das agências internacionais, o regime de governança estabelecido seria baseado no modelo principal-agente. Os Estados, na condição de principais, estariam assim, delegando à agência internacional questões de harmonização e relações internacionais, cujos custos de transação em se realizar bilateralmente com todos os membros seriam muito altos. Tal lógica já é quebrada por Abbott, 2015, ao propor seu modelo de orquestração:

Figura 27 - Modelo de orquestração.

\section{Organização Internacional}

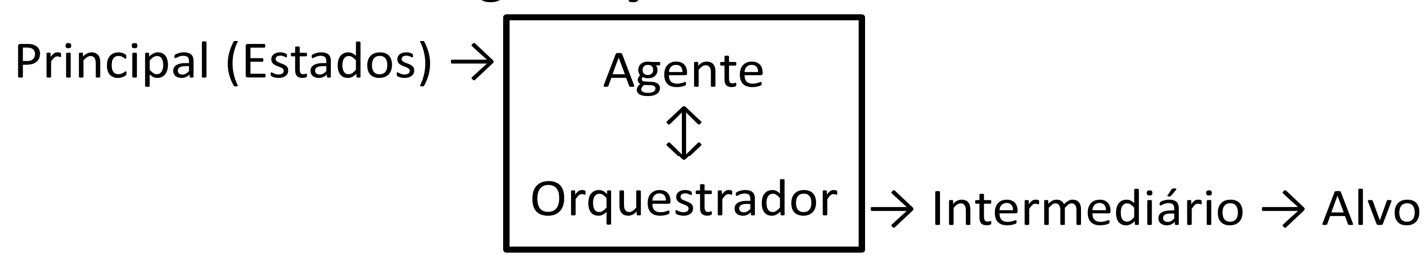

Fonte: Abbott (2015).

Para Abbott, 2015, no entanto, as Organizações Internacionais Governamentais (IGO - International intergovernamental organizations) em algumas situações, deixam de ser meros agentes e passam a ser orquestradores, podendo ignorar, influenciar e até constranger a atuação e o posicionamento dos Estados. Há, portanto, a inserção na cadeia de mais um agente com características e capacidade próprias, conforme mostra a figura a seguir:

Figura 28 - Inserção de mais um agente na cadeia de governança global, o intermediário.

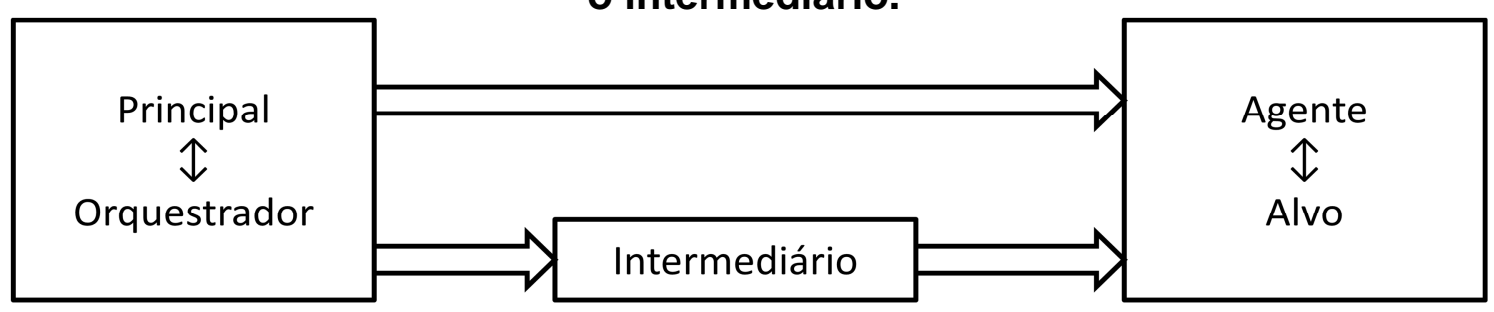

Fonte: elaborado pelo autor. 
Formalmente, a UIT funciona de acordo com o modelo principal-agente, com os Estados membros e contribuintes da agência tendo poder de voto e de deliberação em assembleias e conferências. Entretanto, os Estados têm capacidade limitada para tratar de desenvolvimento e evoluções tecnológicas, especialmente após o processo de desregulação do setor de telecomunicações.

Essa assimetria de informação facilita processos de captura (STIGLER, 1971; NOLL, 1989) não só de agências reguladoras nacionais, mas também da agência internacional. Nesse sentido, pode-se entender a agência internacional como uma mediadora de interesses, assim como uma agência nacional. Entretanto, enquanto originalmente a mediação dos interesses seria somente dos Estados membros, hoje se verifica uma gama maior de atores, como membros setoriais (prestadoras, fabricantes), academia e associados (vide item 2.2.4 deste trabalho).

A percepção de que o modelo de principal-agente não caracteriza bem o funcionamento atual da UIT está em sua forma de funcionamento. A construção de relatórios, recomendações e outras publicações regulatórias da UIT são feitas em uma sistemática orientada por contribuições (contribution driven). Nessa sistemática, o trabalho dos grupos de estudo é conduzido pelas contribuições enviadas para as reuniões, que as discute, podendo incluir ou não seu conteúdo e, até mesmo, fazer alterações no texto proposto. Desta forma, os documentos vão seguindo sua cadeia de aprovação por meio de consensos somente entre aqueles que estão presentes nas reuniões. Não há, portanto, uma requisição formal de aprovação de todos os membros da UIT, mas sim a aprovação por aqueles que participam do fórum responsável por aquele documento. A ausência de presença ou de manifestação é considerada consentimento.

Além de sua capacidade limitada para tratar questões tecnológicas, restrições orçamentárias, dentre outras restrições, podem impedir uma participação mais efetiva de alguns Estados nos trabalhos de organismos internacionais. Com isso, agentes transnacionais podem servir de meio de comunicação entre o que está sendo discutido internacionalmente, para a agenda nacional. Esse mecanismo de comunicação reforça a assimetria de 
informação, já que o portador da mensagem pode selecionar somente aquilo que é de seu interesse comunicar.

A figura a seguir ilustra mais claramente como pode funcionar o mecanismo de governança:

Figura 29 - Modelo de orquestração para o caso concreto estudado.

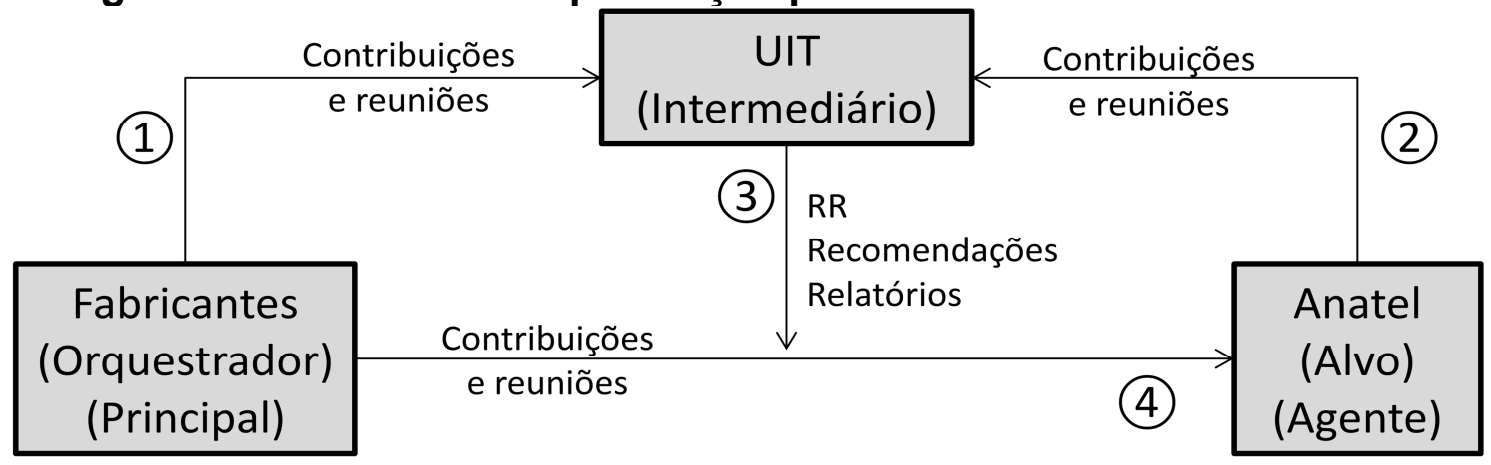

Fonte: elaborado pelo autor.

No diagrama acima, cada uma das setas tem o seguinte significado:

(1) Envio de contribuições à UIT pelos fabricantes, bem como participação nas reuniões de grupos de estudos e outros fóruns da organização;

(2) Envio de contribuições à UIT pela Anatel e outros órgãos reguladores de radiocomunicações, bem como participação nas reuniões de grupos de estudos e outros fóruns da organização;

(3) Publicação pela UIT de diversos documentos, os quais podem ser utilizados por outros agentes para legitimação de seus posicionamentos;

(4) Envio de contribuições à Anatel e demais órgãos reguladores de radiocomunicações. Essas contribuições podem fazer referência a publicações da UIT, como o Radio Regulations, Recomendações e Relatórios.

Ao contrário do modelo originalmente desenvolvido por Abbott, $2015 \mathrm{em}$ que a organização internacional está na posição de orquestrador, no modelo ora proposto os fabricantes ou desenvolvedores tecnológicos ocupam esse papel. Eles atuam diretamente junto ao organismo internacional (UIT) e junto a agência reguladoras nacional (Anatel). No caso das agências reguladoras nacionais, essa participação é mais discreta, envolvendo o envio de contribuições e sugestões em consultas públicas e participando de reuniões. 
No caso da agência internacional, no formato em que a UIT funciona, sua participação pode ser bem mais efetiva, pois elas podem atuar diretamente na escrita das diversas publicações da entidade.

As contribuições enviadas às agências reguladoras nacionais podem ainda fazer referência a publicações da UIT, como recomendações, relatórios ou até mesmo o Radio Regulations (principal documento editado pela UIT sobre radiocomunicações). A referência a documentos da UIT busca dar maior legitimidade a essas contribuições, dar a elas um caráter universal e neutro, já que foi desenvolvida em uma sistemática participativa e com muitos lados. Esse fato torna-se particularmente interessante quando se considera que os próprios fabricantes são agentes importantes na construção de tais documentos. Desta forma, é possível também problematizar a neutralidade de tais publicações.

Apesar do exposto, não se pode negligenciar a participação dos Estados nacionais na UIT. Eles estão lá e participam das decisões. É bem verdade que existe também uma grande desigualdade de representação, tanto numérica, já que países menos desenvolvidos têm maiores dificuldades de participação, mas também tecnológica, pois países líderes tendem a propor temas, problemas e soluções que muitas vezes não estavam nas agendas dos países tecnologicamente menos desenvolvidos.

Não se pode imaginar, entretanto, que as diversas relações são pautadas apenas por conflito. Há que se mencionar que existem interesses complementares, especialmente se se considerar as categorias de agentes. Tais interessem complementares estão resumidos abaixo:

- Fabricantes: que a adoção de tecnologias desenvolvidas por eles sejam adotadas pelas prestadoras em todos os países;

- Prestadoras: que haja diminuição de seus custos, especialmente por meio de padrões mais harmônicos;

- Agência reguladora nacional:

- Inventivo dos padrões desenvolvidos nacionalmente;

- Que o padrão adotado internamente não se distancie dos padrões internacionais. 
- UIT: que haja um único ou o mínimo possível de padrões de radiofrequência pelo mundo (harmonização).

Desta forma, os interesses da UIT, das prestadoras e da Agência reguladora nacional não se distanciam e se complementam. Todos esses atores querem a harmonização de padrões, não tendo, de maneira geral, grandes preferências por um padrão e por outro. $O$ ator que tem interesse em que um padrão específico seja adotado é o fabricante. Para esse ator, a adoção de um padrão por ele desenvolvido torna-se fontes de royalties, enquanto que a adoção por outro, torna-se despesa, pelo pagamento de tais encargos.

Cabe destacar ainda o caso especial de uma agência reguladora que tenha por objetivo o incentivo a padrões desenvolvidos nacionalmente. Esse caso ocorre somente em países desenvolvedores de tecnologia e, nesse sentido, pode haver alguma contradição de objetivos. Por um lado o regulador quer incentivar a indústria de seu país e, por outro, não quer que seu país fique isolado, com a adoção de algum padrão específico somente para ele.

Para conciliação desses objetivos (de ter uma indústria de vanguarda e, ao mesmo tempo, padrões com escalda mundial) esses reguladores têm que editar seus padrões antes da existência ou estabelecimento de um padrão global ou regional. Desta forma, sua regulamentação não se pauta tanto pela existência de regulamentação internacional, já que, para eles, a regulamentação internacional deve ser construída tendo a sua regulamentação nacional como base. Por esta razão, países desenvolvedores de tecnologia geralmente se fazem presentes nas reuniões de fóruns internacionais de padronização. Essas reuniões fazem parte não só de uma estratégia de harmonização, mas também de desenvolvimento tecnológico.

A tabela abaixo mostra uma correlação entre o número de chairmen dos grupos da UIT-R e o ranking relativo do país no número de inovações para telecomunicações da WIPO (World Intellectual Property Organization Organização Mundial da Propriedade Intelectual) ${ }^{44}$.

\footnotetext{
${ }^{44}$ Considerando a soma de todas as publicações relativas a telecomunicações feitas de acordo com o Tratado PCT (Patent Cooperation Treaty) entre os anos de 2000 e 2015 (consulta feita em 28/09/2015 à página http://ipstats.wipo.int/ipstatv2/editSearchForm.htm?tab=pct).
} 
Figura 30 - Comparação entre o número de chairmen da UIT-R e a posição no ranking de patentes de telecomunicações.

\begin{tabular}{|c|c|c|}
\hline País & Número de Chairmen & $\begin{array}{l}\text { Posição no ranking } \\
\text { de patentes }\end{array}$ \\
\hline Estados Unidos & 18 & 1 \\
\hline China & 8 & 4 \\
\hline Rússia & 8 & 18 \\
\hline Austrália & 7 & 14 \\
\hline Emirados Árabes & 6 & 35 \\
\hline França & 6 & 8 \\
\hline Itália & 5 & 13 \\
\hline Japão & 5 & 2 \\
\hline Reino Unido & 5 & 9 \\
\hline Alemanha & 4 & 6 \\
\hline Coréia do Sul & 4 & 3 \\
\hline Egito & 4 & 43 \\
\hline Holanda & 4 & 10 \\
\hline Índia & 4 & 21 \\
\hline Irã & 4 & - \\
\hline Brasil & 3 & 27 \\
\hline Canadá & 3 & 11 \\
\hline Costa do Marfim & 3 & - \\
\hline México & 3 & 38 \\
\hline Nigéria & 3 & 85 \\
\hline Camarões & 2 & 53 \\
\hline Líbano & 2 & - \\
\hline Omã & 2 & - \\
\hline África do Sul & 1 & 25 \\
\hline Arábia Saudita & 1 & 46 \\
\hline Espanha & 1 & 16 \\
\hline Gabão & 1 & - \\
\hline Guiné & 1 & - \\
\hline Israel & 1 & 12 \\
\hline Quatar & 1 & - \\
\hline
\end{tabular}




\begin{tabular}{|l|r|r|}
\hline País & Número de Chairmen & $\begin{array}{l}\text { Posição no ranking } \\
\text { de patentes }\end{array}$ \\
\hline Quenia & 1 & 80 \\
\hline Suécia & 1 & 5 \\
\hline Suíça & 1 & 15 \\
\hline Ucrânia & 1 & 34 \\
\hline Vietnã & 1 & \\
\hline
\end{tabular}

Fonte: elaborado pelo autor.

Como se pode perceber, alguns países têm uma posição de liderança mais destacada na UIT do que seu desenvolvimento tecnológico poderia sugerir. Essa aparente disparidade está relacionada a questões não tecnológicas, como a liderança de bloco geográfico, como a RCC (Regional Commonwealth in the Field of Communications), ASMG (Arab Spectrum Management Group) e ATU (African Telecommunications Union) ${ }^{45}$, dentre outros aspectos geopolíticos e até mesmo de carisma pessoal, aspectos não abordados neste trabalho.

Apesar dessas peculiaridades, percebe-se uma tendência de que o grau de inovação, medido pelo número de patentes publicadas, é um importante parâmetro para que um país se destaque em número de chairmen na UIT.

\subsubsection{Hipóteses teóricas para orquestração}

No item 1.3.4 deste trabalho, foram descritas as hipóteses gerais de orquestração, que são retomadas neste ponto para aplicação no caso concreto. As hipóteses, resumidas na Tabela 2, e que são tratadas individualmente são as seguintes:

- Capacidades do orquestrador;

- Disponibilidade de intermediários;

- Focalidade do orquestrador; e

- Empreendedorismo do orquestrador.

\subsubsection{Capacidades do orquestrador}

Vogel (1996), ao entrevistar o vice-secretário da Associação Britânica de Bancos, reportou a seguinte frase do entrevistado ${ }^{46}$ :

\footnotetext{
45 Além dos grupos regionais citados, também são reconhecidos pela UIT a CITEL (Inter-American Telecommunication Commission) e a APT (Asia-Pacific Telecommunity).

${ }^{46}$ Tradução livre.
} 
Os reguladores estão todos na mesa em que a legislação é feita - e nós não.

Essa frase resume o desejo de todo regulado: participar do processo regulatório de modo que a regulação atenda seus interesses. Entretanto, a captura, conforme previsto por Stigler (1971), é um mecanismo demasiadamente direto e de fácil percepção e crítica pela sociedade. Modos mais indiretos e sofisticados podem ser buscados a fim de que uma regulamentação possa atender a requisitos formais de legitimidade $e$ imparcialidade.

Desta forma, falta ao orquestrador, entendido neste caso como os fabricantes e desenvolvedores de soluções tecnológicas, a capacidade de estabelecer padrões a serem adotados por meio de legislação/regulamentação. Esse déficit de capacidade induz esses agentes a buscar meios para emular tais capacidades, uma vez que são detentores de grande vantagem competitiva em relação aos reguladores, qual seja a assimetria de informação em relação a tecnologia. A orquestração é, portanto, uma solução bastante interessante para definição de padrões que atendam a seus interesses.

Em resumo, falta ao orquestrador as seguintes capacidades:

- Capacidade para regular;

- Legitimidade para regular;

- Imparcialidade de seu posicionamento (neutralidade).

A primeira das capacidades é de competência para regular. A tarefa de estabelecer legislação é privativa dos agentes de Estado, por seu caráter obrigatório. Por envolver um bem público, o espectro de radiofrequência é gerido de maneira menos flexível do que outros aspectos da regulamentação de telecomunicações. Essa competência tem se mantido como uma competência estatal, mesmo após a grande desestatização vislumbrada no setor de telecomunicações em quase todo o mundo.

A segunda é a legitimidade. Diferentemente de um Estado democrático, em que as funções de regulação são exercidas por agentes legitimados pelo voto ou outra forma republicana de escolha de representantes, para os agentes de mercado não há qualquer processo que lhe garanta essa característica. 
Praticamente como corolário da segunda, a terceira capacidade é a imparcialidade de posicionamento. Como as empresas desenvolvedoras de tecnologia têm interesses próprios e não se pode assumir que eles buscam o bem comum, como seria esperado de um agente imparcial.

\subsubsection{Disponibilidade de intermediários}

Esta hipótese diz que quanto maior a quantidade de possíveis intermediários, mais provável será o desenvolvimento da orquestração. Nesta questão, há uma situação bastante peculiar para o caso estudado.

A UIT é o fórum histórico para discussão entre Estados sobre telecomunicações. Há, no entanto, possibilidades de edição de padrões por comunidades privadas e associações. Por não serem estabelecidos por Estados, esses padrões são voluntários, podendo ser caracterizados como soft law. São exemplos desses fóruns o 3GPP (3rd Generation Partnership Project), - IEEE (Institute of Electrical and Electronics Engineers) e o ETSI (European Telecommunications Standards Institute).

Os padrões desenvolvidos por esses institutos servem, muitas vezes, de base para regulamentações nacionais, que lhes confere legitimidade. Além disso, por não serem entidades efetivamente reguladas ou agentes de mercado, os padrões desenvolvidos por eles não são marcados claramente com tendenciosos, sendo tratados como neutros e imparciais.

A UIT também goza de tais atributos. Além disso, por fazer parte do sistema ONU, a UIT goza de certa reputação ante a sociedade. Um Estado, ao adotar um padrão dessa natureza, traz para si parte da reputação da ONU, além de uma imagem de integração internacional e competência. Essa vinculação reforça a credibilidade na agência reguladora nacional, que é um atributo também buscado pelos reguladores a fim de dar a necessária segurança a investidores, especialmente estrangeiros (MELO, 2001; MUELLER e PEREIRA, 2002).

A UIT tem também um diferencial em relação a outros fóruns. Enquanto que a adoção de padrões desenvolvidos em fóruns privados possa trazer a necessária confiança aos investidores estrangeiros de poder utilizar padrões com escalas globais, parte da sociedade pode ser cética em relação á neutralidade desses fóruns. A UIT, por ser originalmente formada por Estados 
e ser o sistema ONU, goza de maior legitimidade do que fóruns privados. Por esta razão, ter um "selo" UIT é um atributo sempre importante e buscado pelos fabricantes.

Importante ressaltar também a maior abertura à participação de agentes privados e o incentivo à sua participação proporcionada pela UIT nos últimos tempos. Tal abertura está descrita na Resolução no 14 da Conferência de Plenipotenciários da UIT, realizada em Antalya, na Turquia, em 2006, denominada de "Reconhecimento dos direitos e obrigações de todos os Membros Setoriais da UIT". 47 Em parte, esta maior abertura foi influenciada pelo maior protagonismo do setor privado em detrimento dos Estados após a desregulação do setor de telecomunicações e pela ascensão de modelos de governança multissetorial, especialmente para Internet (KLEINWÄCHTER, 2007).

A maior abertura da UIT também sugere que uma orquestração passa a ser mais interessante do que uma ação direta dos fabricantes sobre os reguladores nacionais ao estilo principal-agente. Por não ser a última instância decisória, a UIT pode ser mais permeável a influências da iniciativa privada sem que isso macule a sua legitimidade. Os Estados, por sua vez, não podem ter esse nível de abertura, com participação direta de agentes privados nas instâncias decisórias.

Como se percebe, a maior abertura da UIT foi incentivada pela pressão competitiva advinda da formação de fóruns privados. Com essa adaptação, a UIT mantém seu status central nas discussões sobre telecomunicações, mas com várias ameaças ao seu protagonismo. Desta forma, a existência de potenciais intermediários, mesmo que não tenham todas as virtudes da UIT, foram importantes para que a orquestração se tornasse um instrumento viável para os fabricantes e desenvolvedores de tecnologia.

\subsubsection{Focalidade do orquestrador}

A hipótese de focalidade do orquestrador está relacionada à sua liderança inconteste naquele setor. Essa característica facilitaria a orquestração, pois o orquestrador poderia arregimentar mais facilmente os intermediários necessários para atingimento de seus objetivos.

\footnotetext{
${ }^{47}$ Tradução livre do original disponível em:

https://www.itu.int/council/groups/stakeholders/Background-Documents/final-acts.doc
} 
No presente caso, a liderança inconteste de algum fabricante ou desenvolvedor de tecnologia não se vislumbra em nível global. Existem sim líderes regionais, conforme divisão descrita no item 2.2 deste trabalho, mas se observa uma intensa competição (FRANSMAN, 2010) em escala global.

Entretanto, a disponibilidade da UIT como possível intermediário e sua dependência dos conhecimentos tecnológicos detidos pelos fabricantes enfraquece a necessidade desta hipótese para ocorrência da orquestração. Não é necessário neste cenário a criação ou fomento de um intermediário. Ele já existe e tem as características que faltam ao orquestrador, tais como: neutralidade, impessoalidade e interface com os reguladores.

Por outro lado, a participação na UIT não é fácil. Existem custos para se manter como membro, participar das reuniões é custoso e manter-se informado exige dedicação de mão de obra especializada. Essas dificuldades operacionais limitam a participação de muitos agentes, especialmente de países em desenvolvimento.

Apesar de iniciativas da UIT para mitigar tais dificuldades ${ }^{48}$, conhecer a UIT, seus procedimentos e publicações não é para todos. Tal questão traz mais focalidade aos agentes que conseguem participar desse fórum.

Mesmo com essas dificuldades, percebe-se, assim, uma maior disponibilidade de orquestradores do que de intermediários, o que, em parte, diverge da hipótese inicial de orquestração desenvolvida por Abbott (2015). Entretanto, a interdependência de ambos, reforçada pelas capacidades complementares desses atores dá o necessário estímulo à colaboração entre as partes.

\subsubsection{Empreendedorismo do orquestrador}

Esta hipótese é a de que a orquestração será mais provável se a estrutura organizacional e a cultura incentivarem o empreendedorismo. $\mathrm{Na}$ hipótese levada a cabo neste estudo de que os orquestradores são os fabricantes ou desenvolvedores de tecnologia, essa hipótese é confirmada.

\footnotetext{
${ }^{48}$ Resoluções sobre esse tema na conferência de Plenipotenciários da UIT (Busan, 2014):

- Resolução $\mathrm{n}^{\circ} 12$ - Acesso online às publicações da UIT.

- Resolução $\mathrm{n}^{\circ} 167$ - Fortalecimento e desenvolvimento das capacidades da UIT para reuniões eletrônicas e meios para avançar os trabalhos da União.

- Resolução ${ }^{\circ} 170$ - Admissão de Membros Setoriais de países em desenvolvimento na participação dos trabalhos da UIT-R e UIT-T.
} 
De maneira geral, os desenvolvedores de tecnologia são empresas privadas, que têm o empreendedorismo como valor. Ao perceber na UIT um intermediário, os orquestradores veem uma vantagem competitiva para a sua atuação e vão para esse fórum defender seus interesses. A dinâmica competitiva do setor exige esse empreendedorismo.

Outro fator importante para a necessidade de empreendedorismo são as rápidas mudanças tecnológicas. Como alguma liderança setorial pode ser suplantada rapidamente, a capacidade de inovação é uma característica importante do ator que está na condição de orquestrador neste setor. Portanto, a capacidade de empreender iniciativas é uma virtude importante para uma orquestração bem sucedida.

\subsubsection{Desenvolvimento de um mecanismo de difusão para o caso concreto}

O que se percebe é que, no presente caso, a orquestração está sendo utilizada como mecanismo de governança, mas também como mecanismo de difusão. Com isso, algumas das hipóteses devem ser alteradas.

A hipótese de que falta ao orquestrador alguma capacidade deve ser mantida, pois se não houvesse algum déficit de capacidade, o modelo principal agente poderia ser a resposta mais imediata aos objetivos de difusão. Aos fabricantes faltam alguns atributos, como neutralidade e legitimidade para elaboração de padrões que possam ser aceitos com maior facilidade. Por esta razão, é interessante para eles o engajamento numa orquestração.

A hipótese de disponibilidade de intermediários deve ser relativizada. No uso de orquestração como modelo de governança, a competição entre os intermediários deixa o orquestrador numa posição de barganha vantajosa. No entanto, no caso de uso de orquestração para objetivos de difusão, a pouca disponibilidade ou praticamente unicidade de atores que tenham as características necessárias para contribuir na difusão altera a relação orquestrador-intermediário.

Com objetivos de governança, a relação orquestrador-intermediário é praticamente contratual. $\mathrm{O}$ orquestrador utiliza $\mathrm{O}$ intermediário para realizar algo que ele próprio não conseguiria fazer sozinho. Enquanto que no caso de difusão, o orquestrador consegue participar da governança do intermediário. 
Não é simplesmente uma relação contratual, pois os delegados dos países centrais, ou dos fabricantes são também parte da UIT. Eles, assim, conseguem usar dois chapéus (double hatted), o de sua entidade original e o de contribuidor da UIT (EGEBERG e TRONDAL, 2009).

Outra hipótese que deve ser relativizada é a da focalidade do orquestrador. Da mesma maneira da hipótese de disponibilidade de intermediários, quem tem focalidade, no caso de difusão, é o intermediário e não o orquestrador. A competição ocorre então entre os possíveis orquestradores. A UIT, na condição de intermediário, é quem tem uma posição diferenciada.

A hipótese de empreendedorismo do orquestrador vale da mesma maneira tanto para o caso de governança, quanto para o caso de difusão. É necessário que o orquestrador tenha um comportamento proativo para fazer sua representação junto à UIT e defender seus pontos de vistas e interesses. Além disso, outro fato facilitador para a difusão é a abertura da UIT a participação de agentes não estatais, como os fabricantes e também a academia. Se essa participação fosse vedada, ou complicada, as dificuldades de utilização da UIT com objetivos de difusão seriam maiores.

Para resumir este argumento, a tabela abaixo compara as hipóteses de orquestração entendida como modo de governança ou de difusão: 
Tabela 16 - Comparação entre as hipóteses para orquestração quando entendida como governança e como difusão.

\begin{tabular}{|c|c|c|c|}
\hline \multicolumn{4}{|c|}{ Os atores tendem a orquestrar, quando: } \\
\hline \multicolumn{2}{|c|}{ Governança } & \multicolumn{2}{|c|}{ Difusão } \\
\hline $\begin{array}{l}\text { Capacidades do } \\
\text { orquestrador } \\
\text { (capacidades } \\
\text { complementares } \\
\text { entre } \\
\text { orquestradores } \\
\text { e intermediários) }\end{array}$ & $\begin{array}{l}\text { Aos orquestradores } \\
\text { faltam certas } \\
\text { capacidades para } \\
\text { atingir seus objetivos } \\
\text { por meio de outros } \\
\text { modos } \\
\text { governança. }\end{array}$ & $\begin{array}{l}\text { Capacidades } \\
\text { do } \\
\text { intermediário } \\
\text { (capacidades } \\
\text { complementar } \\
\text { es entre } \\
\text { orquestrador e } \\
\text { intermediário) }\end{array}$ & $\begin{array}{l}\text { Aos orquestradores } \\
\text { faltam certas } \\
\text { capacidades para } \\
\text { atingir seus objetivos } \\
\text { por meio de outros } \\
\text { modos de difusão. }\end{array}$ \\
\hline $\begin{array}{l}\text { Disponibilidade } \\
\text { de } \\
\text { intermediários }\end{array}$ & $\begin{array}{lr}\text { Disponibilidade } & \text { de } \\
\text { intermediários com } \\
\text { objetivos } \\
\text { correlacionados } \\
\text { capacidades } \\
\text { complementares. }\end{array}$ & $\begin{array}{l}\text { Existência de } \\
\text { interessados } \\
\text { na difusão } \\
\text { (orquestrador } \\
\text { es) }\end{array}$ & $\begin{array}{ll}\text { Quanto maior } & \text { o } \\
\text { número } & \text { de } \\
\text { interessados } & \text { na } \\
\text { difusão, maiores as } & \text { de } \\
\text { chances } & \text { dossíveis } \\
\text { orquestradores } & \\
\text { necessitarem de um } \\
\text { intermediário. }\end{array}$ \\
\hline $\begin{array}{l}\text { Focalidade do } \\
\text { orquestrador }\end{array}$ & $\begin{array}{lrr}\text { Eles são } & \text { focais } \\
\text { dentro da } & \text { área } \\
\text { temática. } & & \\
& \end{array}$ & $\begin{array}{l}\text { Focalidade do } \\
\text { intermediário }\end{array}$ & $\begin{array}{l}\text { Eles são focais } \\
\text { dentro da área } \\
\text { temática. } \\
\text { focalidade facilita a } \\
\begin{array}{l}\text { especialização } \\
\text { formação de uma } \\
\text { comunidade. }\end{array}\end{array}$ \\
\hline $\begin{array}{l}\text { Empreendedoris } \\
\text { mo do } \\
\text { orquestrador }\end{array}$ & $\begin{array}{l}\text { Sua estrutura } \\
\text { organizacional } \\
\text { cultura encorajam o } \\
\text { empreendedorismo } \\
\text { de políticas públicas. }\end{array}$ & $\begin{array}{l}\text { Arranjo } \\
\text { institucional } \\
\text { que incentive } \\
\text { a participação }\end{array}$ & 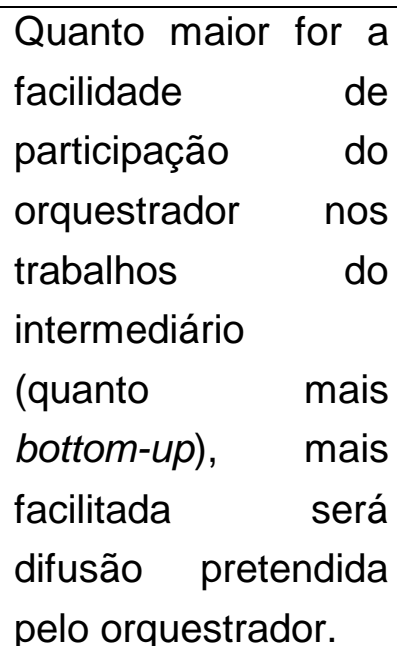 \\
\hline
\end{tabular}

Fonte: elaborado pelo autor. 
Feitas essas considerações, percebe-se que as hipóteses para orquestração, quando considerada um modo de difusão, servem para responder à pergunta de pesquisa. Essas hipóteses respondem quais fatores determinam a influência das agências especializadas na ONU nas tomadas de decisão por agências reguladoras brasileiras.

Elas também ilustram como a UIT e outros fóruns internacionais podem servir de intermediários na disseminação de políticas. Este fato corrobora as hipóteses H1 e H1.1, descritas na seção 3.3, de que há influência relevante de uma agência da ONU e de que ela pode ser utilizada como a intermediária do modelo de orquestração para fins de difusão.

Considera-se, assim, que há transferência de política pública (policy transfer), pois a escolha de um arranjo em um ou mais países tecnologicamente centrais condiciona as escolhas dos países tecnologicamente menos desenvolvidos, por serem eles (países tecnologicamente centrais) os produtores de equipamentos soluções que serão posteriormente utilizados nos demais países.

Com os ganhos de escala, característica dos sistemas de telecomunicações, o modo tradicional de compreender a difusão seria de que a decisão de um arranjo de frequências em um país tecnologicamente central influencia diretamente os países tecnologicamente seguidores. Há aqui também uma externalidade de rede, pois na medida em que mais países adotam determinado padrão, maior a probabilidade que outros possam aderir.

Entretanto, há um mecanismo subjacente que é a utilização da UIT e outros fóruns internacionais para disseminação de tais padrões como mecanismo de comunicação que potencializa a difusão. Percebe-se que cada tipo de agente utiliza as publicações internacionais para legitimar seus interesses ante a entidade reguladora nacional. Essa forma de atuação pode ser considerada uma orquestração, por envolver um intermediário, neste caso os fóruns internacionais.

O mecanismo tradicional para compreensão de transferência de políticas públicas é por meio das comunidades epistêmicas ou alguma outra forma que possibilite a fácil e efetiva circulação de ideias (DOLOWITZ e MARSH, 2000). A UIT e outros fóruns internacionais têm essa função, mas são mais que isso. A 
UIT e outros fóruns de padronização produzem um resultado formal, que é uma publicação, seja ela um padrão (Standard), uma Recomendação, um Relatório ou documentos com caráter mais impositivo, como uma alteração num tratado internacional, o Radio Regulations. Essa publicação, teoricamente neutra, pode ser utilizada para legitimação de políticas nacionais ou sub-regionais que pretendem difundir-se para além de suas fronteiras.

Assim, propõe-se como contribuição teórica, um novo mecanismo de difusão, a transferência orquestrada de política pública (orchestrated policy transfer). Esse modelo diferencia-se da transferência de políticas públicas tradicional, da coerção, do isomorfismo e do aprendizado. Esse mecanismo é condizente com a definição de orquestração como mecanismo não hierárquico (soft) e indireto.

De fato, não é um mecanismo hierárquico puro, nem heterárquico puro. A UIT e outros fóruns não têm hierarquia sobre as administrações nacionais e suas agências, mas têm capacidade de limitar suas decisões, especialmente no caso de países não desenvolvedores de tecnologia. Tampouco é um mecanismo completamente soft, já que há certa penalização daqueles que não seguem padrões mundiais pela perda de escala (aumento dos custos de produção) ou simplesmente a indisponibilidade de equipamentos para o padrão escolhido (vide caso de $450 \mathrm{MHz}$ no Brasil) ${ }^{49}$.

A construção do modelo de orquestração originalmente não teve como objetivo a descrição de um mecanismo de difusão ou mais especificamente de transferência de política pública, mas a descrição de um mecanismo de governança (ABBOTT, 2015). O objetivo primordial era compreender o modus operandi de organizações internacionais, e não como a atuação dessas agências influencia na governança de agências nacionais. Por isso, há em Abbott (2015) a premissa de que os organismos internacionais estariam na condição de orquestradores, o que não é uma necessidade do presente estudo.

\footnotetext{
${ }^{49}$ Para a faixa de $450 \mathrm{MHz}$, o Brasil optou por fazer um arranjo de radiofrequências próprio, o qual foi levado à UIT e consta da Recomendação M.1036-4. Entretanto, a padronização do uso da tecnologia LTE só aconteceu em momento posterior e também houve dificuldades para que equipamentos fossem produzidos para esse arranjo. Alguns detalhes podem ser encontrados na seguinte reportagem: http://www.telesintese.com.br/operadoras-avaliam-Ite-em-450-mhz-so-para-2015-fornecedores-saomais-otimistas/
} 
Ao não se adotar tal premissa, pode-se observar que organizações internacionais podem também ser utilizadas como intermediários e, devido às suas relações com diversos países do mundo, acabar sendo utilizados como instrumentos para difusão de políticas, conceitos e valores.

Assim, a transferência orquestrada de política pública não seria nem uma forma bottom-up, nem uma forma top-down, como pressupõem os modelos de difusão tradicionais. É um modo híbrido e que ocorre em duas etapas. A primeira etapa é de interação entre orquestrador e intermediário e, na segunda, há a relação entre intermediário e agente. A figura abaixo ilustra tal mecanismo:

\section{Figura 31 - Modelo de orquestração aplicado para difusão de políticas} públicas (transferência orquestrada de política pública).

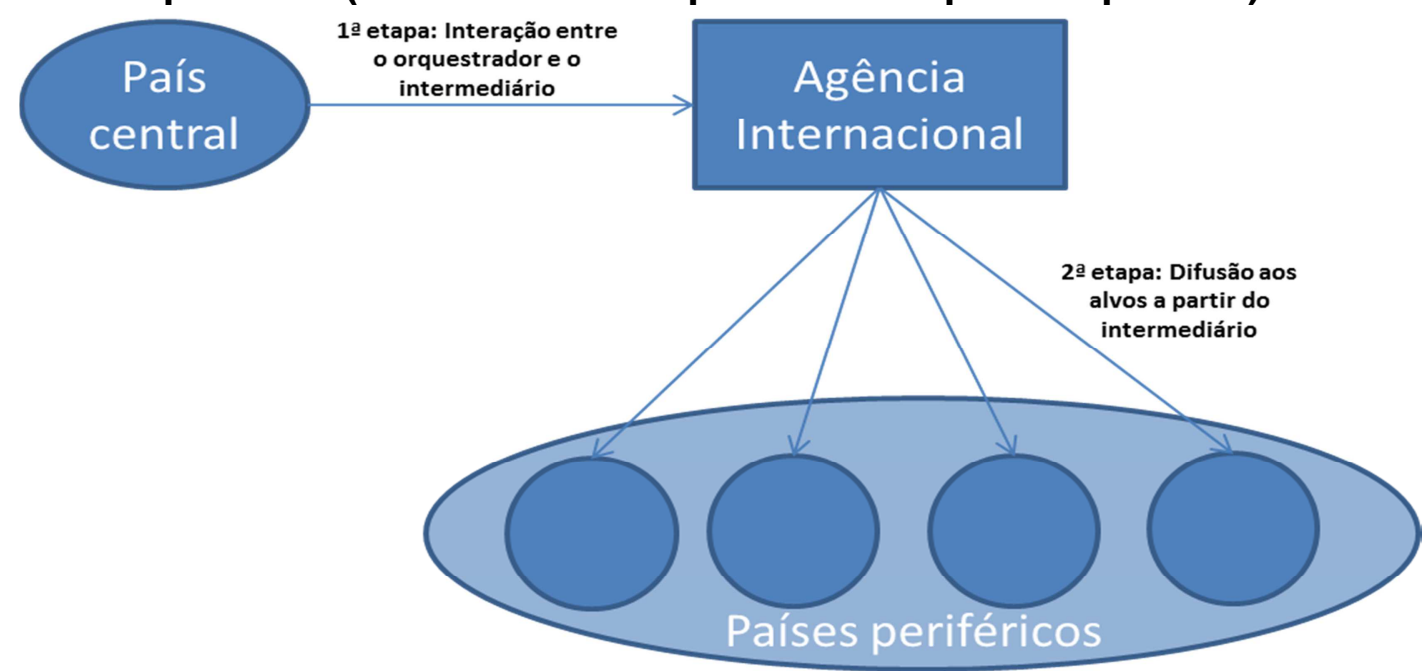

Fonte: elaborado pelo autor.

Tal explicação assemelha-se à explicação hierárquica proposta por LeviFaur (2005) para expansão do capitalismo regulatório. Entretanto, ela se diferencia em um aspecto: a explicação de Levi-Faur (vide Figura 1) ocorre em um único passo, ou seja, o interesse de difusão é do país central ou da agência internacional. No modelo ora proposto, a agência internacional é inserida como intermediária, o que leva à existência de duas etapas para que a difusão possa acontecer. Assim, não é uma transferência de política pública de um país a outro, mas uma transferência mediada por organismo internacional ou algum outro fórum com capacidade de padronização, o que caracteriza um novo modo de difusão, a transferência orquestrada de política pública. 


\subsubsection{Independência da Agência Reguladora e domínio tecnológico}

Um fato bastante curioso é observar que não houve nenhuma contribuição de alguma pessoa identificada como de alguma universidade. Isso é bastante negativo, quando se observa pelo ponto de vista de modelos de relação Estado-sociedade para geração de inovação.

Um dos modelos mais conhecido é o do Triângulo de Sábato, assim representado:

Figura 32 - Modelo do Triângulo de Sábato.

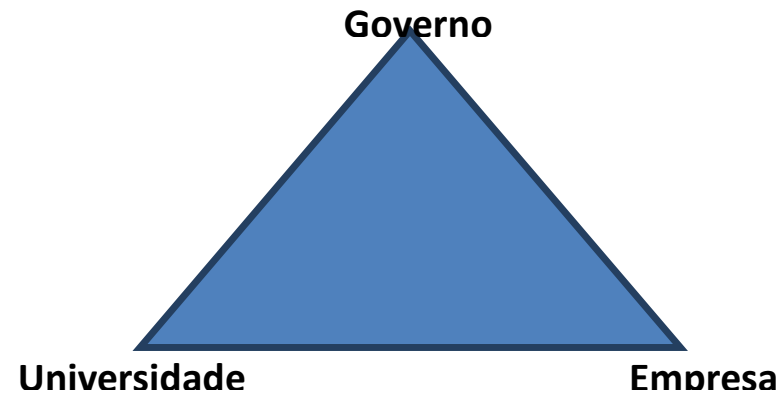

Fonte: elaborado pelo autor.

Como se pode observar, esse modelo coloca o Governo numa posição privilegiada em relação aos outros agentes, mas reconhece a importância da Academia. Esse modelo foi sendo substituído pelos modelos de hélice tripla (triple helix), de modo a representar o papel mais proativo e independente das universidades e das empresas, destacando-se ainda mais a importância de um setor acadêmico articulado com as iniciativas do governo e com as empresas do setor privado.

Ao longo do tempo, os modelos de triple helix também foram se diferenciando, gerando três versões:

- Triple Helix I - neste modelo, as três esferas são definidas institucionalmente $e$ as interações são instituições formais, como transferências de tecnologias, contratos, etc.

- $\quad$ Triple Helix II - neste modelo as interações entre as esferas são mais distribuídas e informais;

- $\quad$ Triple Helix III - neste modelo as três esferas assumem diferentes papéis, além de seus papéis tradicionais e as fronteiras entre elas passam a ser menores. 
Nesse último modelo, em especial, a transferência de conhecimento não é mais um processo linear, já que as interações entre os agentes são mais difusas e seus papéis mais sobrepostos.

Segundo Shima (2007), para o setor de telecomunicações o paradigma de Triple Helix já existe, tendo como dimensão geográfica global, em que as relações ocorrem por meio de alianças globais estratégicas. Nessas relações, os agentes brasileiros não estão incorporados, a não ser como mercados alvo, pois os processos de inovação são desenvolvidos nos países de origem dos grandes conglomerados que adquiriram as prestadoras de telecomunicações ou que são origem dos grandes fornecedores de equipamentos. Tal consequência é observada empiricamente pela grande presença de grupos tecnológicos com sede fora do Brasil e ausência de universidades brasileiras na discussão sobre uso de espectro.

Observando-se a capacidade de geração de tecnologia para o setor de telecomunicações por meio das estatísticas da WIPO, tem-se que o Brasil está nas seguintes posições, de um total de 130 países $^{50}: 2^{\circ}$ (Telecomunicações),

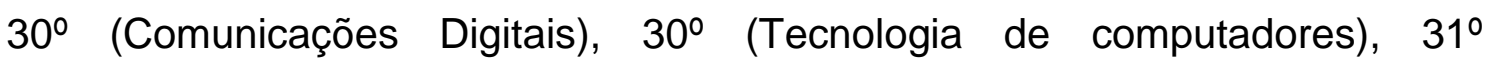
(Processos básicos de comunicação). Ou seja, o país está em posições intermediárias, o que também é indicado pela análise das consultas públicas, já que a Anatel foi capaz de questionar várias contribuições que mencionavam a UIT. Constatação similar foi feita pelo presidente da Sociedade Brasileira da Computação ao perceber que o Brasil é um voraz consumidor de TIC, mas está fora do protagonismo na geração de tecnologias ${ }^{51}$.

Há que se observar também a baixa integração do modelo de regulação de telecomunicações com o setor de pesquisa e desenvolvimento. Apesar de existirem iniciativas com 0 objetivo de promover 0 desenvolvimento tecnológico, como a existência do Funttel, o arranjo institucional regulatório não foi feito com esse objetivo.

Percebe-se isso claramente, por exemplo, quando se observa a constituição do Conselho Consultivo da Agência. Esse conselho tem seus

\footnotetext{
${ }^{50}$ Considerando a soma de todas as publicações feitas de acordo com o Tratado PCT (Patent Cooperation Treaty) entre os anos de 2000 e 2015 (http://ipstats.wipo.int/ipstatv2/editSearchForm.htm?tab=pct).

${ }^{51}$ Fonte: http://convergenciadigital.uol.com.br/cgi/cgilua.exe/sys/start.htm?infoid=40703\&sid=104
} 
membros $^{52}$ indicados pelo Senado Federal, pela Câmara dos Deputados, pelo Poder Executivo, pelas entidades de classe das prestadoras de serviços de telecomunicações, por entidades representativas dos usuários e por entidades representativas da sociedade, mas não tem membros indicados pela academia.

Apesar de haver previsão legal de estímulo ao desenvolvimento tecnológico, o que se percebe é pouca integração fática entre a política regulatória setorial e a política de inovação e desenvolvimento tecnológico. As tentativas de incentivo ao desenvolvimento tecnológico estiveram relacionadas ao estabelecimento de obrigações às prestadoras de aquisição de equipamentos fabricados ou desenvolvidos no país, o que não traz sinergias, nem oportunidades para desenvolvimento e inovação, já que apenas cria reservas de mercado, sem alterar as relações institucionais existentes.

Apesar de o Brasil não estar bem posicionado nos rankings tecnológicos do setor $^{53}$, nem a participação da Anatel e de outros agentes nacionais em fóruns internacionais ser comparável a dos líderes tecnológicos, observa-se que há capacidade técnica para questionar informações provenientes de tais fóruns. O que se percebe como limitada é a capacidade de que o Brasil possa desenvolver padrões tecnológicos que possam se firmar em escala global.

Mesmo na condição de seguidor tecnológico, é importante observar o quão distante o país está dos líderes em termos temporais. Neste quesito, pode-se comparar quando ocorreram alguns eventos importantes relacionados a radiocomunicações e que tem impactos também na indústria de equipamentos e soluções. Foram escolhidos quatro eventos com grande impacto para a sociedade da informação:

1. Data na qual houve liberação de espectro de radiofrequências nas quais se poderia implantar tecnologias consideradas 3G;

2. Data na qual houve liberação de espectro de radiofrequências nas quais se poderia implantar tecnologias consideradas $4 \mathrm{G}$;

3. Quando foi tomada a decisão para o desligamento da TV analógica; e

4. Quando esse desligamento ocorreu ou foi previsto.

\footnotetext{
${ }^{52}$ Art. 34 da LGT.

${ }^{53}$ Menciona-se aqui que rankings também podem ser uma forma de influência (JARVIS, 2014).
} 
A tabela abaixo resume quando esses eventos ocorreram para alguns países líderes em tecnologia da informação e comunicação.

Tabela 17 - Eventos da política de espectro em alguns países.

\begin{tabular}{|l|l|l|l|l|}
\hline & $\begin{array}{l}\text { Frequências } \\
\text { para 3G }\end{array}$ & $\begin{array}{l}\text { Frequências } \\
\text { para 4G }\end{array}$ & $\begin{array}{l}\text { Quando a decisão } \\
\text { do switch off da } \\
\text { TV offalógica foi da switch } \\
\text { tomada? }\end{array}$ & $\begin{array}{l}\text { Data do } \\
\text { off } \\
\text { analógica }\end{array}$ \\
\hline Brasil & 2007 & 2012 & 2006 & $2018^{56}$ \\
\hline EUA & $2002^{57}$ & $2008^{58}$ & $1996^{59}$ & $2009^{60}$ \\
\hline Japão & $2001^{61}$ & $2009^{62}$ & $2001^{63}$ & $2011^{64}$ \\
\hline Coréia do Sul & $2002^{65}$ & 2011 & $2001^{66}$ & $2012^{67}$ \\
\hline Suécia & $2000^{68}$ & $2009^{69}$ & $2003^{70}$ & $2007^{71}$ \\
\hline Alemanha & $2000^{72}$ & $2010^{73}$ & $1998^{74}$ & 2009 \\
\hline
\end{tabular}

Fonte: elaborado pelo autor.

No caso do desligamento da TV analógica, além da rapidez com que a decisão é tomada, deve-se observar também a capacidade que o país tem de implementar suas ações e não só de tomada de decisão. Desta forma,

\footnotetext{
${ }^{54}$ Entendido como licença para operar sistemas IMT-2000 (International Mobile Telecommunications)

${ }^{55}$ Entendido como a licença para operação de sistemas LTE - Long Term Evolution.

${ }^{56}$ A data inicial de 2016 (Decreto 5.820/2006) foi alterada para 2018 pelo Decreto 8.061/2013.

${ }^{57}$ http://transition.fcc.gov/3G/

58 http://www.fcc.gov/topic/700-mhz

59 http://www.fcc.gov/topic/digital-television

60 http://www.fcc.gov/topic/digital-television

61 http://www.itu.int/osg/spu/ni/3G/casestudies/japan/JAPAN 3G.PDF

62 Ministério de Assuntos internos e comunicações (http://www.soumu.go.jp/main sosiki/joho tsusin/eng/presentation/pdf/090619 1.pdf)

${ }^{63}$ http://www.soumu.go.jp/main sosiki/joho tsusin/eng/presentation/pdf/120315.pdf

64 http://www.soumu.go.jp/main sosiki/joho tsusin/eng/presentation/pdf/120315.pdf

65 http://www.pts.se/upload/Documents/EN/3G\%20rollout\%20status\%20\%20a\%20report\%20about\%20the\%203G\%20status\%20in\%20Europe\%20-\%20PTS-ER-2002-22.pdf
}

http://eng.kcc.go.kr/user.do?mode=view\&page $=E 02010400 \& d c=E 02010400 \&$ boardld $=1050 \& c p=1 \&$ boa $\frac{\mathrm{rdSeq}=15660}{67}$

http://eng.kcc.go.kr/user.do?mode=view\&page $=E 02010400 \& d c=E 02010400 \&$ boardld $=1050 \& c p=1 \&$ boa $\mathrm{rdSeq}=15660$

${ }^{68} \mathrm{http}: / /$ www.pts.se/upload/Documents/EN/The\%20Mobile\%20Telecommunications\%20Market.pdf

${ }^{69} \mathrm{http} / / /$ www.pts.se/upload/Rapporter/Tele/2010/2010-26-swedish-telecom-market-half-year2010.pdf

${ }^{70} \mathrm{http}: / /$ www.cisionwire.com/teracom/r/historisk-overgang-till-digital-tv,c305991

${ }_{72}^{71}$ http://www.cisionwire.com/teracom/r/historisk-overgang-till-digital-tv,c305991

http://www.bundesnetzagentur.de/cln 1912/EN/Areas/Telecommunications/TelecomsRegulation/Freq uencyManagement/UniversalMobileTelecommunicationsSystemUMTS/UMTSUniversalMobTelecomSyst em Basepage.html

http://www.bundesnetzagentur.de/SharedDocs/Downloads/EN/BNetzA/PressSection/PressReleases/20 11/111215 ActivityReportPostTK.pdf? blob=publicationFile

${ }^{74}$ http://www.ero.dk/9BEC9548-849D-4AC3-8DA3-C703DEBD8274?frames=no\& 
percebe-se que o Brasil, além de tomadas de decisão de vanguarda, há também que aprimorar seus processos internos de modo a garantir que migrações tecnológicas ocorram de maneira célere. Um exemplo dessa dificuldade foi a demora em que fosse realizada a migração de tecnologias analógicas de telefonia móvel para tecnologias digitais, inicialmente programadas em 2008 (tomada da decisão em 2006) e até hoje (2016) seu desligamento ainda está em curso.

A tabela abaixo resume a distância temporal entre a regulamentação brasileira e dos países líderes selecionados para comparação.

Tabela 18 - Distância temporal entre o Brasil e os países líderes na política de radiocomunicações.

\begin{tabular}{|l|c|c|c|}
\hline & $\begin{array}{l}\text { Ano de referência } \\
\text { (ano em que o } \\
\text { primeiro país } \\
\text { tomou a decisão) }\end{array}$ & $\begin{array}{l}\text { Diferença entre o } \\
\text { Brasil e a média } \\
\text { dos países } \\
\text { comparados }\end{array}$ & $\begin{array}{l}\text { Diferença entre } \\
\text { o Brasil e o país } \\
\text { líder }\end{array}$ \\
\hline $\begin{array}{l}\text { Quando a decisão } \\
\text { do switch off da } \\
\text { TV analógica foi } \\
\text { tomada? }\end{array}$ & 1996 & 6,2 anos & 10 anos \\
\hline $\begin{array}{l}\text { Frequências para } \\
\text { 3G }\end{array}$ & 2000 & 6 anos & 7 anos \\
\hline $\begin{array}{l}\text { Switch off da TV } \\
\text { analógica }\end{array}$ & 2007 & 8,5 anos & 11 anos \\
\hline $\begin{array}{l}\text { Frequências para } \\
\text { 4G }\end{array}$ & 2008 & 2,6 anos & 4 anos \\
\hline
\end{tabular}

Fonte: elaborado pelo autor.

Desta forma, comparando-se a disponibilização de frequências para 3G e 4G, percebe-se uma aproximação do Brasil com os líderes mundiais. No que se refere ao desligamento da TV analógica, o distanciamento é maior do que o relativo às frequências do $4 \mathrm{G}$. Isso reflete que a decisão relacionada ao desligamento da TV analógica foi tardia, uma vez que um grande intervalo de tempo se passou para que o Brasil tomasse a decisão do padrão que iria escolher e consequentemente 0 prazo para implantação também foi postergado.

Interessante observar que o Brasil adotou um sistema de TV digital baseado no padrão japonês, o que reflete, mais uma vez, a posição intermediária do Brasil de desenvolvimento tecnológico. O país baseou o seu modelo num modelo estrangeiro, mas fez adaptações para que ele pudesse se 
adequar melhor à realidade nacional e às evoluções tecnológicas ocorridas desde o lançamento do padrão original.

Nessas comparações relativas à defasagem de adoção de alocações de espectro, há que se fazer a ressalva que possivelmente os ciclos tecnológicos podem ter se encurtado e a distância relativa entre Brasil e os países líderes não ter sido significativamente diminuída.

No entanto, há outros indicadores que reforçam a percepção de que o Brasil está se aproximando dos países líderes, como as taxas de penetração de serviço, as taxas de transmissão e os minutos de uso. Este catch-up não acontece de maneira muito rápida, uma vez que a oferta deve ser acompanhada por uma demanda equivalente. Neste caso, como a oferta de espectro é controlada pelo Estado por meio da destinação e de editais de licitação, a disponibilização de espectro estimula a adoção de novas tecnologias e, para que exista o catch-up, há de existir na sociedade uma demanda equivalente, de modo a não comprometer as operações.

Outro fato bastante interessante relacionado à não detenção de domínio tecnológico é a possibilidade de terceirização de responsabilidade por parte do Estado. Ao se adotar uma recomendação internacional, a responsabilidade pode ser dividida com a entidade que endossa tal política pública. Esse comportamento minimiza o risco de imputação de responsabilidade por algum resultado indesejado, o que é buscado especialmente numa situação de rápidas mudanças tecnológicas sobre as quais não se tem controle ou grande previsibilidade. Essa constatação lança também a possibilidade de estudo para outros mercados em que há rápidas evoluções tecnológicas, como o setor de medicamentos, também acompanhado por uma agência reguladora, a Anvisa (Agência Nacional de Vigilância Sanitária). 


\section{CONCLUSÃO}

Neste trabalho, buscou-se aprimorar a compreensão sobre 0 funcionamento das Agências Reguladoras por meio do estudo de caso da regulamentação de destinação e de uso de radiofrequências (radiocomunicações). O intuito foi verificar como as influências internacionais são processadas pela agência reguladora setorial. Para isso, foram aplicadas teorias que consideram influências externas na regulamentação nacional, caracterizando o caso como uma difusão de políticas públicas, mais especificamente uma transferência de política pública (policy transfer). Como a aplicação de modelos dessa natureza são raros para explicar o funcionamento dessas autarquias, especialmente no Brasil, este estudo pretendeu dar sua contribuição a esse campo.

A criação da Anatel e de várias outras agências reguladoras nacionais está vinculada a uma expansão do capitalismo regulatório, descrita teoricamente por Levi-Faur (2005) e ilustrada em estudos brasileiros, como o de Amaral (2000). Esse movimento, utilizado para explicar a criação das Agências Reguladoras, pode também explicar parte de seu funcionamento atual. Assim, diferentemente de outros estudos que se focam na criação das agências, este estudo deu sua contribuição para a compreensão do momento posterior, com a Anatel já instalada.

A análise do processo de construção da regulamentação de espectro no Brasil demonstrou a inserção do setor de telecomunicações num contexto global. Além disso, demonstrou a importância de fóruns internacionais de padronização, não só os formados por Estados, como a UIT, mas também fóruns privados, como o 3GPP. Essa percepção, já endereçada na literatura sobre governança global, dá destaque a agentes internacionais no cenário de influências sobre as agências reguladoras. Esses agentes (internacionais) são frequentemente negligenciados na literatura clássica de regulação, que se foca em fatores domésticos advindos do Governo, do setor regulado e da sociedade (usuários dos serviços regulados).

Com a aplicação de um modelo de governança para compreensão de um fenômeno de difusão, foi possível a proposição de um novo modelo teórico de difusão, a transferência orquestrada de política pública (orchestrated policy 
transfer). Esse modelo diferencia-se da transferência de política pública e de outros mecanismos de difusão, pois é um mecanismo mediado por um intermediário, neste caso um organismo internacional ou algum outro fórum internacional com capacidade de padronização. Esse modelo diferencia-se dos estudos feitos em Abbott (2015), uma vez que não é utilizada a premissa de que o organismo internacional esteja na condição de orquestrador, o que também traz consequências às hipóteses para orquestração traçadas no estudo original.

A proposição desse novo modelo foi necessária para fornecer uma explicação que está além dos elementos presentes em teorias de difusão existentes. O modelo proposto possibilita a compreensão de um modo de atuação mais sofisticado para a difusão global de políticas públicas e de como diversos agentes se comportam na busca de seus interesses perante uma Agência Reguladora. Com esse novo modelo, espera-se que um novo olhar e uma nova importância possam ser dados ao impacto da governança global na edição de normas nacionais.

Como foi percebido pelos dados empíricos, as publicações internacionais, como as da UIT e de outros fóruns privados, importam e fazem o papel de legitimador de contribuições dos entes privados. Essa constatação corrobora as hipóteses levantadas no capítulo 4, o que responde em parte a pergunta de pesquisa formulada. O reconhecimento da importância de publicações internacionais pode parecer tão simples quanto reconhecer que as instituições importam, mas, às vezes, simples constatações passam despercebidas e suas consequências não são seriamente consideradas.

Por essas constatações, há que se perceber que a atuação estatal não é só limitada pelas previsões constitucionais e legais. Questões econômicas já são reconhecidas pela literatura que trata de análise de impacto regulatório (RAMALHO, 2009), entretanto, em geral, o domínio tecnológico não é levado em consideração. Isso reflete a importância de se desenvolver um arranjo institucional adequado para o sistema setorial de inovação.

Tanto a capacidade técnica, como a possibilidade de regulação por meio de redes regulatórias globais limitam as capacidades de escolha de um regulador. A falta de domínio e liderança tecnológicos dificulta uma participação 
mais contundente em fóruns internacionais e em toda a cadeia de governança global sobre regulação de espectro de radiofrequência, um importante insumo para prestação de serviços de telecomunicações. A dificuldade em participar de redes e fóruns globais dificulta com que problemas e soluções brasileiros possam ser considerados em cenário internacional. Com isso, a regulação nacional fica refém e incorpora questões pautadas internacionalmente, que não necessariamente são os problemas reais da sociedade e, tampouco, são as soluções tecnológicas que endereçam da melhor maneira os problemas existentes.

Percebe-se que o surgimento de novas tecnologias implica em novos problemas regulatórios nos países líderes antes que eles apareçam nos países periféricos. Assim, quando determinado país decide implantar determinada tecnologia (sistemas de comunicações móvel de $4^{\mathrm{a}}$ geração, por exemplo), a implantação vem acompanhada de um pacote de medidas regulatórias correspondentes. No caso de radiocomunicações, para que novas tecnologias possam ser implementadas, a destinação e o arranjo de radiofrequências são medidas regulatórias necessárias, os quais, em geral, já estão padronizados antes da decisão do ente regulador nacional, limitando suas possibilidades de escolha.

Assim, o estudo revelou o valor estratégico da regulamentação de radiofrequências. Como foi visto, as normas supranacionais têm a capacidade de servir de plataforma para exercício de poder de influência por aqueles que dominam a sua edição. Para se conseguir tal feito, os agentes que estão na vanguarda tecnológica valem-se da assimetria de informação gerada pelo domínio tecnológico para conseguir aprovar publicações supranacionais e utilizá-las para influenciar os demais agentes.

A literatura sobre sistemas setoriais de inovação destaca que o aprendizado e as capacidades dos agentes, no caso as Agências Reguladoras, são restritas pela tecnologia, conhecimento e contexto institucional (MALERBA, 2009). Por esta razão, a importância do desenvolvimento tecnológico da 
sociedade foi destacada neste estudo como um atributo para a desejada independência da entidade reguladora setorial ${ }^{75}$.

Portanto, as características para autonomia das Agências Reguladoras não se restringem às características formais e factuais propostas por GILLARDI e MAGGETTI (2011). Há que se considerar aspectos cognitivos, como o desenvolvimento tecnológico, algo já percebido em estudos sobre difusão (DUNLOP, 2009). Não exatamente domínio completo dos conhecimentos pelo regulador, já que ele não é desenvolvedor de tecnologia e isso seria utópico, mas sim o domínio pelos provedores de solução nacionais, que podem desenvolver soluções adequadas para os problemas específicos do país e não estão pautados por uma agenda global. Este fato reconhece a importância do contexto e do ecossistema de regulação, conforme já havia reconhecido Fransman (2010) para o setor de tecnologia da informação.

No contexto europeu, onde as redes de reguladores e as relações de interdependência são estudadas há mais tempo, percebe-se a influência de países com maior "capacidade administrativa" e maior "experiência" sobre aqueles que ainda estão aprendendo a se comportar nesses ambientes (MARTENS, 2008). O critério de "experiência" é compreendido por dois atributos: a falta de familiaridade e a falta de uma agenda preestabelecida. Com isso, países com maior "capacidade administrativa" e "experiência" podem capturar a rede de reguladores e, consequentemente, os reguladores nacionais. Nesse sentido, fóruns internacionais podem ser utilizados por países tecnologicamente centrais como facilitadores da difusão de arranjos institucionais, de políticas públicas e de tecnologias.

O argumento deste trabalho é que a participação em fóruns internacionais, que gera experiência, bem como a maior capacidade administrativa são reflexos de um domínio tecnológico e consequente necessidade de defesa da posição de domínio. A "experiência" e a "capacidade técnica" não podem ser entendidas como dadas, mas como uma construção nacional (pública e privada) para expansão de suas regulações e

\footnotetext{
75 Amaral (2000), ao estudar a criação da Anatel, já destaca a importância do desenvolvimento tecnológico ao mencionar que "Organismos internacionais têm influenciado crescentemente as políticas públicas dos países quase sempre subdesenvolvidos, seja em função da supremacia do conhecimento técnico que possuem seja pela vinculação a fontes de investimentos internacionais cada vez mais escassos".
} 
possivelmente de seus mercados. Nesse sentido, a assimetria tecnológica funciona de maneira similar à assimetria de informação, pois pode levar a um mecanismo de captura do regulador.

No caso brasileiro de regulamentação das radiocomunicações, percebese que o país tem capacidade de contestar contribuições que referenciam publicações de organismos internacionais. Entretanto, o desenvolvimento tecnológico setorial ainda não é suficiente para que o país se insira como um dos países centrais na governança global para normatização do uso do espectro.

Por fim, há que se reconhecer ainda as limitações deste trabalho, bem como as possibilidades de estudos futuros. Não se pretendeu neste trabalho desenvolver um modelo causal que levaria à compreensão completa de todos os fatores que influenciam a Anatel. Para essa compreensão, deveriam ser levados em consideração fatores domésticos, que não estão presentes neste trabalho, mas poderão ser explorados em estudos futuros. Outra vertente não explorada é o agendamento da regulamentação de radiocomunicações. Como a análise pautou-se especialmente nas contribuições a consultas públicas, a questão a ser regulamentada já estava presente na agenda da agência e o estudo de como essa agenda é formada pode trazer inúmeras contribuições sobre o funcionamento da Agência Reguladora. O que poderia também render aprendizados importantes seria o estudo de aspectos relacionados aos editais de licitação de radiofrequência, o que não foi abordado neste estudo. Não se pode deixar de mencionar a possibilidade da realização de estudos envolvendo outros setores, como o de aviação civil e de fármacos, que certamente ilustrariam variações institucionais que não foram percebidas neste estudo. 


\section{BIBLIOGRAFIA}

ABBOTT, Kenneth W.; SNIDAL, Duncan. International standards' and international governance. Journal of European Public Policy, v. 8, n. 3, p. 345370, 2001.

ABBOTT, Kenneth W. et al. (Ed.). International Organizations as Orchestrators. Cambridge University Press, 2015.

AMARAL, Aline D. O processo de formulação do novo arcabouço regulatório dos serviços de telecomunicações no Brasil. Master's thesis, University of Brasilia, 2000.

BENNETT, Colin J. What is policy convergence and what causes it?. British journal of political science, v. 21, n. 02, p. 215-233, 1991.

BRAITHWAITE, John. Regulatory capitalism: How it works, ideas for making it work better. Edward Elgar Publishing, 2008.

CASTRO, Marcus Faro de. Economic Development and the Legal Foundations of Regulation in Brazil. The Law and Development Review, v. 6, n. 1, p. 61-115, 2013.

COASE, Ronald $\mathrm{H}$. The federal communications commission. Journal of law and economics, p. 1-40, 1959.

COÊLHO, Denilson Bandeira. Political competition and the diffusion of conditional cash transfers in Brazil. Brazilian Political Science Review, v. 6, n. 2, p. $56-87,2012$.

CORREA, Paulo et al. Regulatory governance in Brazilian infrastructure industries. The Quarterly Review of Economics and Finance, v. 48, n. 2, p. 202216, 2008.

CROLEY, Steven P. Public interested regulation. Fla. St. UL Rev., v. 28, p. 7, 2000.

DERTHICK, Martha; QUIRK, Paul J. The politics of deregulation. Brookings Institution Press, 2001

DOLOWITZ, David P., \& David MARSH., 1996. Who Learns what from Whom: a Review of the Policy Transfer Literature. Political Studies, XLIV, 343-357.

DOLOWITZ, David P., \& David MARSH., 2000. Learning from abroad: The role of policy transfer in contemporary policy-making. Governance - An International Journal of Policy and Administration 13 (1): 5-24. 
EGEBERG, Morten; TRONDAL, Jarle. National agencies in the European administrative space: government driven, commission driven or networked?.Public Administration, v. 87, n. 4, p. 779-790, 2009.

DIMAGGIO, P. et al. \& POWELL, WW (1991). The iron cage revisited: Institutional isomorphism and collective rationality in organizational fields. W. Powell, \& PJ (Eds.), The new institutionalism in organizational analysis, p. 63$82,7$.

DUNLOP, Claire A. Policy transfer as learning: capturing variation in what decision-makers learn from epistemic communities. Policy studies, v. 30, n. 3, p. 289-311, 2009.

EVANS, Peter. O Estado como problema e como solução. Lua Nova: Revista de Cultura e Política, São Paulo, n. 28/29, p. 107-156, 1993.

FRANSMAN, Martin. The new ICT ecosystem: Implications for policy and regulation. Cambridge University Press, 2010.

GILARDI, Fabrizio; MAGGETTI, Martino. 14 The independence of regulatory authorities. Handbook on the Politics of Regulation, v. 201, 2011.

GRUBER, Harald. The economics of mobile telecommunications. Cambridge University Press, 2005.

HARRIS, Richard A.; MILKIS, Sidney M. The politics of regulatory change: a tale of two agencies. Oxford University Press, USA, 1989.

HENISZ, Witold J.; ZELNER, Bennet A.; GUILLÉN, Mauro F. The worldwide diffusion of market-oriented infrastructure reform, 1977-1999. American Sociological Review, v. 70, n. 6, p. 871-897, 2005.

HORWITZ, Robert Britt. The irony of regulatory reform: The deregulation of American telecommunications. Oxford University Press on Demand, 1991.

KLEINWÄCHTER, Wolfgang. The Power of Ideas: Internet Governance in a Global Multi Stakeholder Environment. Marketing für Deutschland, 2007.

JARVIS, Darryl SL. Policy transfer, neo-liberalism or coercive institutional isomorphism? Explaining the emergence of a regulatory regime for quality assurance in the Hong Kong higher education sector. Policy and Society, v. 33, n. 3, p. 237-252, 2014.

LEINER, Barry M. et al. A brief history of the Internet. ACM SIGCOMM Computer Communication Review, v. 39, n. 5, p. 22-31, 2009. 
LEVI-FAUR, David. The global diffusion of regulatory capitalism. The Annals of the American Academy of Political and Social Science, v. 598, n. 1, p. 12-32, 2005.

LEVI-FAUR, David. Regulatory networks and regulatory agencification: towards a Single European Regulatory Space. Journal of European Public Policy, v. 18, n. 6, p. 810-829, 2011.

LEVIN, Harvey J. The invisible resource: use and regulation of the radio spectrum. Routledge, 2013.

LOWI, Theodore J. Four systems of policy, politics, and choice. Public administration review, p. 298-310, 1972.

MAGGETTI, Martino; GILARDI, Fabrizio. The policy-making structure of European regulatory networks and the domestic adoption of standards.Journal of European Public Policy, v. 18, n. 6, p. 830-847, 2011.

MALERBA, Franco; MANI, Sunil (Ed.). Sectoral systems of innovation and production in developing countries: actors, structure and evolution. Edward Elgar Publishing, 2009.

MARTENS, Maria. Runaway bureaucracy? Exploring the role of nordic regulatory agencies in the European Union. Scandinavian Political Studies, v. 31 , n. 1, p. 27-43, 2008.

MCCUBBINS, Mathew D.; SCHWARTZ, Thomas. Congressional oversight overlooked: Police patrols versus fire alarms. American Journal of Political Science, p. 165-179, 1984.

MELO, Marcus André. A política da ação regulatória: responsabilização, credibilidade e delegação. Revista Brasileira de Ciências Sociais, v. 16, n. 46, p. 55-68, 2001.

MELO, Marcus André. As agências regulatórias: gênese, desenho institucional e governança. In: ABRUCIO, F.; LOUREIRO, M. R. (Orgs.). O Estado numa era de reformas: os anos FHC. Brasília: Seges-MP, 2002.

MELO, Marcus André. As agências regulatórias: desenho institucional e governança regulatória nas agências federais e estaduais. 2004.

MONTOYA, Miguel Á.; TRILLAS, Francesc. The measurement of the independence of telecommunications regulatory agencies in Latin America and the Caribbean. Utilities Policy, v. 15, n. 3, p. 182-190, 2007. 
MOURA, Mariana Rodrigues de. A criação das agências reguladoras no Brasil: uma análise dos diferentes padrões de agendamento. 2014.

MUELLER, Bernardo; PEREIRA, Carlos. Credibility and the design of regulatory agencies in Brazil. Brazilian Journal of Political Economy, v. 22, n. 3, p. 65-88, 2002.

MUSEY, J. Armand, The Spectrum Handbook, Summit Ridge Group, 2013

NOLL, Roger G. Economic perspectives on the politics of regulation. 1989.

NUNES, Edson de Oliveira. Agências reguladoras e reforma do Estado no Brasil: inovação e continuidade no sistema político institucional. Editora Garamond, 2007.

PINHEIRO, Guilherme Pereira. A Regulação Do Espectro De Radiofrequências No Brasil: Uma Visão Crítica Sob A Perspectiva Dos Bens Públicos, 2015.

PÓ, Marcos Vinicius; ABRUCIO, Fernando Luiz. Desenho e funcionamento dos mecanismos de controle e accountability das agências reguladoras brasileiras: semelhanças e diferenças. Revista de Administração Pública, Rio de Janeiro, v. 40, n. 4, p. 679-98, 2006.

POSNER, Richard A. Theories of economic regulation. 1974.

RADAELLI, Claudio M. Policy transfer in the European Union: institutional isomorphism as a source of legitimacy. Governance, v. 13, n. 1, p. 25-43, 2000. RAMALHO, P.I.s. (org.). Regulação e agências reguladoras: governança e análise de impacto regulatório. Brasília: ANVISA, 2009.

REED, Chris. Taking sides on technology neutrality. SCRIPT-ed, v. 4, n. 3, p. 263-284, 2007.

RYAN, Patrick S. Wireless Communications and Computing at a Crossroads: New Paradigms and Their Impact on Theories Governing the Public's Right to Spectrum Access. Journal on Telecommunications \& High Technology Law, v. 3, n. 2, p. 239, 2005.

SHIMA, W. O desmonte do sistema setorial de inovação em telecomunicações no Brasil e o surgimento de um novo arranjo institucional. Revista de Economía Política de las Tecnologías de la Información y Comunicación, vol. IX, no 2, mai-ago 2007. 
SHIPAN, Charles R.; VOLDEN, Craig. Policy diffusion: Seven lessons for scholars and practitioners. Public Administration Review, v. 72, n. 6, p. 788-796, 2012.

SIMMONS, Beth A.; DOBBIN, Frank; GARRETT, Geoffrey. The global diffusion of public policies: Social construction, coercion, competition or learning?. Annual review of sociology, v. 33, p. 449-472, 2007.

SPADA, Paolo. Political Competition and the Diffusion of Policy Innovations in local government: The case of Participatory Budgeting in Brazil. In:Meeting of the Latin American Studies Association, Toronto, Canada. 2010.

STIGLER, George J. The theory of economic regulation. The Bell journal of economics and management science, p. 3-21, 1971.

SUGIYAMA, Natasha Borges. Theories of policy diffusion: social sector reform in Brazil. Comparative Political Studies, 2007.

VOGEL, Steven Kent. Freer markets, more rules: regulatory reform in advanced industrial countries. Cornell University Press, 1996.

WALKER, Jack $L$. The diffusion of innovations among the American states. American political science review, v. 63, n. 03, p. 880-899, 1969.

WAMPLER, Brian. Participatory budgeting in Brazil: Contestation, cooperation, and accountability. Penn State Press, 2007.

YACKEE, Jason Webb; YACKEE, Susan Webb. A bias towards business? Assessing interest group influence on the US bureaucracy. Journal of Politics, v. 68 , n. 1, p. 128-139, 2006.

YIN, Robert K. Estudo de Caso-: Planejamento e Métodos. Bookman editora, 2015.

YOUNG, Alison. The politics of regulation: privatized utilities in Britain. Palgrave, 2001. 